\section{Pacific Northwest}

National Laboratory

Operated by Battelle for the

U.S. Department of Energy

\title{
Groundwater Protection Program Science and Technology Summary Description
}

\author{
M.D. Freshley \\ A.L. Bunn \\ G.W. Gee \\ T.J. Gilmore \\ C.T. Kincaid \\ R.E. Peterson \\ A.L. Ward \\ S.B. Yabusaki \\ J.M. Zachara
}

November 2002

Prepared for the U.S. Department of Energy under Contract DE-AC06-76RL01830 


\section{DISCLAIMER}

This report was prepared as an account of work sponsored by an agency of the United States Government. Neither the United States Government nor any agency thereof, nor Battelle Memorial Institute, nor any of their employees, makes any warranty, expressed or implied, or assumes any legal liability or responsibility for the accuracy, completeness, or usefulness of any information, apparatus, product, or process disclosed, or represents that its use would not infringe privately owned rights. Reference herein to any specific commercial product, process, or service by trade name, trademark, manufacturer, or otherwise does not necessarily constitute or imply its endorsement, recommendation, or favoring by the United States Government or any agency thereof, or Battelle Memorial Institute. The views and opinions of authors expressed herein do not necessarily state or reflect those of the United States Government or any agency thereof.

\section{PACIFIC NORTHWEST NATIONAL LABORATORY operated by \\ BATTELLE MEMORIAL INSTITUTE for the UNITED STATES DEPARTMENT OF ENERGY under Contract DE-AC06-76RL1830}

\section{Printed in the United States of America}

Available to DOE and DOE contractors from the

Office of Scientific and Technical Information, P.O. Box 62, Oak Ridge, TN 37831;

prices available from (865) 576-8401.

Available to the public from the National Technical Information Service,

U.S. Department of Commerce, 5285 Port Royal Rd., Springfield, VA 22161 


\section{Groundwater Protection Program Science and Technology Summary Description}

M. D. Freshley
A. L. Bunn
G. W. Gee
T. J. Gilmore
C. T. Kincaid
R. E. Peterson
A. L. Ward
S. B. Yabusaki
J. M. Zachara

November 2002

Prepared for the U.S. Department of Energy

under Contract DE-AC06-76RL01830

Pacific Northwest National Laboratory

Richland, WA 99352 


\section{Summary}

The Hanford Site Groundwater Protection Program, formerly the Groundwater/Vadose Zone Integration Project, was established in 1997 to develop the integrated approach, technical capability, and scientific information needed to perform site-wide assessments of the potential effects of Hanford Site soil and groundwater contaminants on people and the ecology. To complete this mission, gaps in scientific understanding and technologies were identified, and research to close those gaps was initiated.

Examples of the contributions science and technology will make over the longer term include quantifying and reducing the uncertainties in inventory estimates used in site-wide risk assessment, testing and evaluating simplifying assumptions made in site-wide assessments, describing the mechanisms for contaminant transport associated with high-level waste tanks that have leaked to the ground, and developing methods and data to reduce the uncertainty in ecological and human-health risk assessments. These contributions will be used to support decisions affecting the extent of single-shell tank waste retrieval needed and final closure of tank farms, as well as remediation of other waste sites at the Hanford Site.

Recently, the U.S. Department of Energy (DOE) Richland Operations Office and the DOE Office of River Protection developed the "Performance Management Plan for the Accelerated Cleanup of the Hanford Site." The Plan outlines six strategic initiatives that, supported by a near-term increase in funding, will put Hanford in position to end the Environmental Management (EM) mission at Hanford by 2035, or sooner, and save tens of billions of dollars. It lays out the Department's commitment to not just accelerated completion of DOE's EM program mission at Hanford, but also to high quality, comprehensive cleanup that protects public health and the environment. The plan calls for DOE to:

- restore the Columbia River corridor by 2012, including decommissioning facilities and remediating waste sites

- end the tank-waste program by 2035, including increasing the capacity of the planned Waste Treatment Plant, accelerating tank closure; and demonstrating alternative treatment and immobilization solutions for lower-risk tank waste

- remove and safely store all spent nuclear fuel, sludge, and water from the K Basins early; accelerate stabilization and storage of plutonium; and dry store cesium/strontium capsules

- accelerate treatment and disposal of mixed-low level waste, retrieve and ship transuranic waste offsite, and coordinate remaining waste site remediation with tank closure

- use regional or other waste-site grouping strategies to clean up facilities and non-tank farm waste sites in the Central Plateau

- protect groundwater resources by removing or isolating important contaminant sources on the Central Plateau, remediating contamination sources exterior to the Central Plateau core zone, reducing drivers for contaminant migration, treating the groundwater, and integrating site monitoring requirements.

This science and technology document describes the current status of the Groundwater Protection Program and plans for future science and technology investments to support cleanup of the Hanford Site. The science and technology investments will continue to evolve, based on the priorities of the Hanford 
Site for accelerating the work scope in the baseline, science and technology work that is funded and performed, and planned additions to the roadmap to include other technical areas, such as monitoring, to support cleanup and long-term stewardship. 


\section{Acronyms}

CERCLA Comprehensive Environmental Response, Compensation, and Liability Act

COS Characterization of Systems

DNAPL dense non-aqueous phase liquid

DOE U. S. Department of Energy

DOE-RL DOE-Richland Operations

EAPS Enhanced Access Penetration System

EM Environmental Management

EMSP Environmental Management Science Program

FIR Field Investigation Report

FY fiscal year

HDW Hanford Defined Waste

HLW High-Level Waste

ILAW Immobilized low activity waste

INEEL Idaho National Engineering and Environmental Laboratory

ITRD Innovative Treatment Remediation Demonstration

LANL Los Alamos National Laboratory

LBNL Lawrence Berkeley National Laboratory

LDMM leak detection, mitigation, and monitoring

LLNL Lawrence Livermore National Laboratory

NABIR natural and accelerated bioremediation

ODOE Oregon Department of Energy

ORP Office of River Protection

OST Office of Science and Technology 


\begin{tabular}{|c|c|}
\hline PUF & pressurized unsaturated flow \\
\hline PUREX & Plutonium Uranium Extraction \\
\hline RCRA & Resource Conservation and Recovery Act \\
\hline REDOX & reduction oxidation \\
\hline RFI & RCRA Facility Investigation \\
\hline RPP & River Protection Project \\
\hline S\&T & Science and Technology \\
\hline SAMMS & Self Assembled Mesoporous Membranes \\
\hline $\mathrm{SAC}$ & System Assessment Capability \\
\hline SAFE & subsurface air flow and extraction \\
\hline SIM & soil inventory model \\
\hline SNM & special nuclear fuel \\
\hline SST & single-shell tank \\
\hline TAG & Technical Advisory Group \\
\hline TPA & Tri-Party Agreement (Hanford Federal Facility Agreement and Consent Order) \\
\hline TRU & transuranic \\
\hline WMA & Waste Management Area \\
\hline XAS & X-ray diffraction \\
\hline
\end{tabular}




\section{Contents}

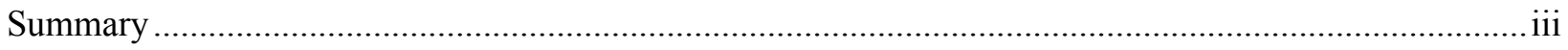

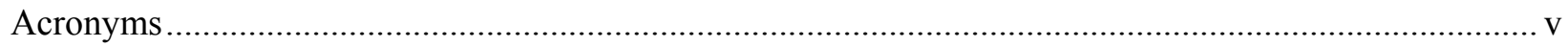

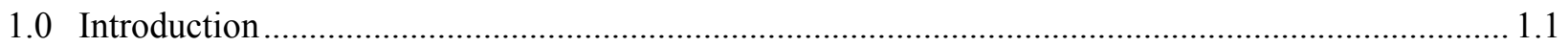

1.1 Objective of the S\&T Project ................................................................................................ 1.1

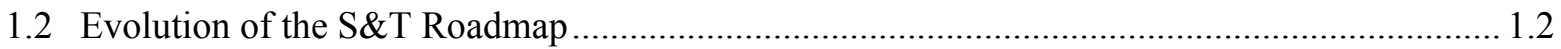

1.3 Approach for Revising the Roadmap .................................................................................... 1.2

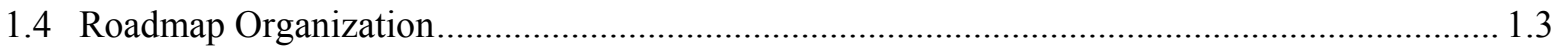

1.4.1 Inventory Technical Element ........................................................................................ 1.3

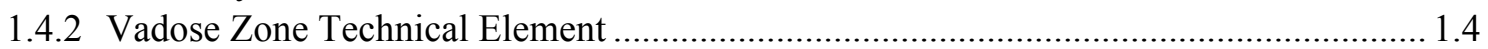

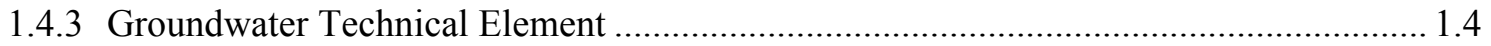

1.4.4 Columbia River Technical Element........................................................................ 1.5

1.4.5 Risk Technical Element ...................................................................................... 1.5

1.4.6 Remediation Technical Element ............................................................................... 1.6

1.4.7 Monitoring Technical Element .................................................................................. 1.6

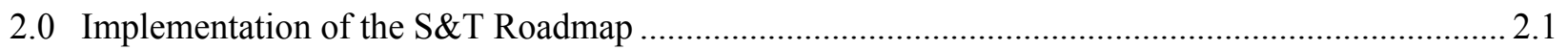

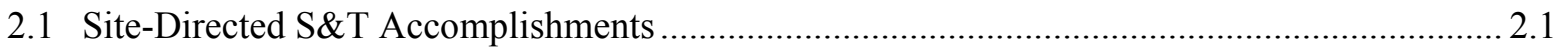

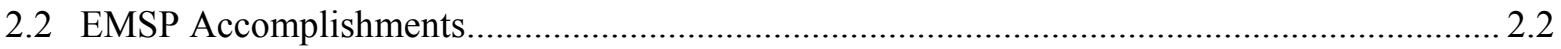

2.3 Science and Technology Linkages with EM-40 and EM-50 ................................................. 2.5

2.4 Core Project Science and Technology Contributions.............................................................. 2.6

2.5 National Research Council Review........................................................................................ 2.7

3.0 Innovative Treatment Remediation Demonstration Projects .............................................................. 3.1

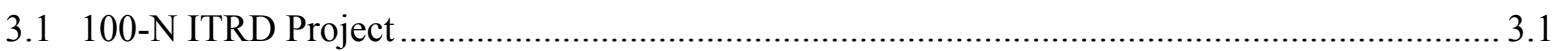

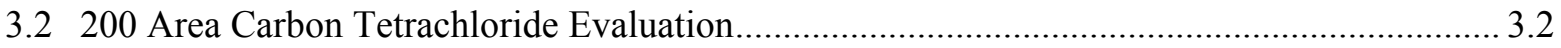

4.0 Schedule of Science and Technology Activities and Outcomes ...................................................... 4.1

5.0 Linkages to the Groundwater Protection Program and Core Projects.................................................. 5.1

5.1 Linkages with Site-Wide Assessments................................................................................ 5.1

5.2 Linkages with the Tank Farm Vadose Zone Project .................................................................. 5.3 
5.3 Linkages with the 200 Area Remedial Action Project .......................................................... 5.4

5.4 Linkages with the River Monitoring Project .................................................................. 5.5

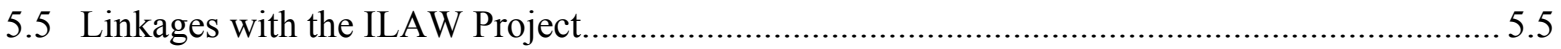

5.6 Linkages with the Performance Management Plan ............................................................. 5.6

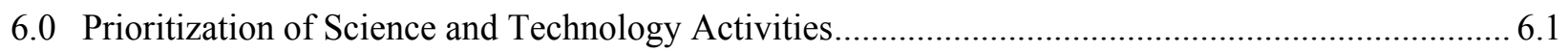

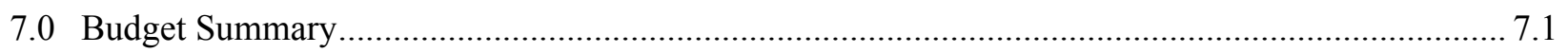

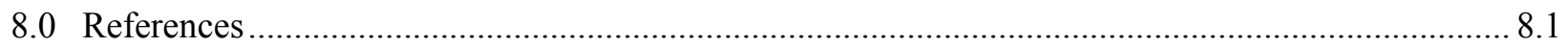

\section{Figures}

4.1. Applied Science and Technology Schedule, Logic, and Linkages ............................................. 4.3

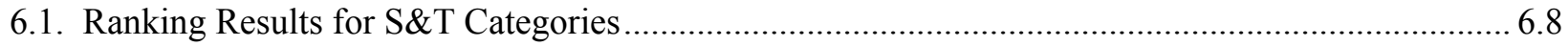

\section{Tables}

4.1. S\&T Schedule and Products for Inventory Technical Element ..................................................... 4.5

4.2. Schedule and Products for Subsurface Transport Technical Element .......................................... 4.8

4.3. Schedule and Products for Columbia River and Risk Technical Element ................................... 4.16

4.4. Schedule and Products for Remediation Technical Element .................................................... 4.21

5.1. Schedules for Site-Wide Assessments and Core Projects ......................................................... 5.2

6.1. Categories of Science and Technology Activities for Prioritization ............................................... 6.4

7.1. Proposed Five-Year Budget for S\&T Activities .................................................................... 7.1 


\subsection{Introduction}

This document is Rev. 2 of the Groundwater Protection Program, formerly the Groundwater/Vadose Zone Integration Project, Science and Technology (S\&T) roadmap. Roadmapping is a process in which problem holders, such as the U.S. Department of Energy (DOE), Tribal Nations, regulators, stakeholders, and remediation contractors, come together with problem solvers, such as scientists and engineers from the national laboratories and universities, to define problems and establish a path to solution. Periodically, these discussions and agreements are documented in revisions of the project's S\&T roadmap. The roadmap describes the S\&T objectives, briefly describes the scope and outcomes of S\&T, links these outcomes to the Groundwater Protection Program, and provides schedule, budget, and priorities for S\&T activities.

The roadmap has provided direction for the S\&T project and has been revised several times. The project began implementing Rev. 0 of the S\&T roadmap (DOE 1999a) in fiscal year 2000 (FY00). Rev. 1 was completed in May 2000 (DOE 2000), adding the risk technical element to the roadmap. Rev. 2 of the S\&T roadmap includes revisions reflecting accomplishments to date and comments by the National Research Council/National Academy of Sciences committee that reviewed the project during FY00 and FY01 (National Research Council 2001); it also adds the soil and groundwater remediation technical element. Future revisions of the roadmap will reflect changes in the Hanford Site baseline and will include the monitoring technical element.

\subsection{Objective of the S\&T Project}

The DOE has established a goal to accelerate the cleanup and closure of the Hanford Site. To achieve this goal, DOE has identified two critical objectives: 1) restoring the Columbia River Corridor and 2) transitioning the Central Plateau to long-term waste management.

The river corridor is a 544-square-kilometer (210-square-mile) area that begins at the shores of the Columbia River and extends inland toward the Central Plateau. Cleanup of the river corridor will make land available for other uses and conserve and protect ecological and historic cultural resources. Cleanup challenges in the Columbia River Corridor include placing nine former plutonium-production reactors in safe storage and decommissioning dozens of associated structures, removing 150 aging facilities and structures that no longer are needed, remediating nearly 900 waste sites, and establishing final remedies for groundwater contaminants.

The Central Plateau is a roughly 194-square-kilometer (75-square-mile) area near the middle of the Hanford Site and includes the 200-East and West Areas. A large number of facilities formerly used for spent-nuclear-fuel processing and plutonium metal production as well as Hanford's 177 underground high-level radioactive waste storage tanks are located in the 200 Areas. The DOE is transitioning the Central Plateau from primarily inactive storage to active waste characterization, treatment, storage, and disposal operations. While a great deal of progress has been made, the existing baseline for cleanup activities in the Central Plateau will continue for more than 40 years.

Recently, the DOE Richland Operations and the DOE Office of River Protection developed the "Performance Management Plan for the Accelerated Cleanup of the Hanford Site." The Plan outlines six 
strategic initiatives that, supported by a near-term increase in funding, will put Hanford in position to end the Environmental Management (EM) mission at Hanford by 2035, or sooner, and save tens of billions of dollars. It lays out the Department's commitment to not just accelerated completion of DOE's EM program mission at Hanford, but also to cleanup that protects public health and the environment. The plan, which calls for DOE to accelerate restoration of the river corridor by 2012, includes the following: 1) remove spent fuel, remediate soil waste sites, and clean up groundwater, 2) accelerate remediation of high-level waste and closure of tank farms, and 3) accelerate remediation of the central plateau by decommissioning facilities, accelerating waste disposal, and accelerating groundwater remediation.

\subsection{Evolution of the S\&T Roadmap}

The S\&T roadmap is a dynamic and evolving document. It provides the basis for planning work scope of the S\&T Project and linking to other DOE programs that provide S\&T solutions, including the Environmental Management Science Program (EMSP), the Office of Science and Technology (OST), and the Office of Science programs, such as Natural and Accelerated Bioremediation (NABIR). The S\&T roadmap is used by the Groundwater Protection Program to develop detailed work plans for each year. The current revision of the roadmap will be used to develop plans for FY 2003. The roadmap was also used to influence a call for proposals by the DOE EMSP in 1999. Principal investigators from across the DOE complex, universities, and private industry responded to the call for proposals. These proposals were subjected to both technical and relevancy reviews, and a certain number of them were funded. Through workshops and interactions with the EMSP investigators, the EMSP projects were linked with the S\&T work scope. The linked EMSP projects were identified in Rev. 1 of the S\&T roadmap.

As with previous drafts of the roadmap, the S\&T outcomes are linked to key decisions facing the Hanford Site and to the projects executing work to address these decisions for the compliance case, i.e., to meet the current Hanford Federal Facility Agreement and Consent Order (Tri-Party Agreement [TPA 1989]). The S\&T outcomes are also linked with the strategic initiatives that accelerate the existing baseline.

\subsection{Approach for Revising the Roadmap}

The approach to revising the S\&T roadmap was to conduct several workshops with representatives of the DOE national laboratories, the DOE Richland Operations and the Office of River Protection, remediation contractors, regulatory agencies, Native American Tribes, and stakeholders participating in the S\&T program. The first workshop was held to update the existing technical elements: inventory, vadose zone, groundwater, Columbia River, and risk. The second workshop was held to develop the soil and groundwater remediation technical element.

The workshop to update the existing technical elements was conducted on January 8 through 10 , 2002. Nearly 70 people participated in the $2 \frac{1}{2}$-day workshop, including staff from both the DOE Richland Operations Office (DOE RL) and the DOE Office of River Protection (DOE ORP), Hanford Site contractors, the Washington State Department of Ecology (Ecology), Oregon Department of Energy (ODOE), several Tribal Nations (Yakama, Nez Perce, Umatilla), stakeholder groups, and representatives from DOE national laboratories - Lawrence Berkeley National Laboratory (LBNL), Lawrence Livermore National Laboratory (LLNL), Los Alamos National Laboratory (LANL), and Idaho National Engineering and Environmental Laboratory (INEEL). The workshop included review and discussion of the S\&T 
Project accomplishments to date, review and discussion of the System Assessment Capability (SAC) results, and consideration of review comments by the National Academy of Sciences/National Research Council committee that recently completed its review of the project. Additional consideration was given to the needs and schedules of the core Hanford Site projects that interact with the S\&T project.

The workshop to develop input for the soil and groundwater remediation technical element was held on February 13 and 14, 2002. Nearly 70 people participated in the 2-day workshop, including staff from both DOE-RL and DOE-ORP, Hanford Site contractors, Ecology, ODOE, the Confederated Tribes of the Umatilla Indian Reservations, and representatives from DOE national laboratories through a Technical Assistance Request to the Subsurface Contaminants (Subcon) Focus Area of the DOE Office of Science and Technology (OST) (EM-50). The Subcon Technical Assistance Team included representatives from Oak Ridge National Laboratory, Sandia National Laboratory, and INEEL. The workshop included a review and discussion of remedial actions currently underway, results of the Innovative Treatment and Remediation Demonstration (ITRD) projects focused on strontium-90 at the 100-N Area and carbon tetrachloride in the 200-West Area, the DOE NABIR Program, and plans for interim surface covers at tank farms.

\subsection{Roadmap Organization}

The S\&T Project is organized into technical elements. The inventory, vadose zone, groundwater, and Columbia River technical elements provide the technical information and data to characterize various features and key processes essential to development of conceptual and numerical models that attempt to describe how the natural system works. The risk-assessment technical elements provide technical information and data to fill in gaps in site-wide system assessments. The remediation element identifies potential improvements to the Hanford Site's cleanup strategy.

This section presents a brief summary of each of the technical elements and general S\&T activities within each of the elements. A more detailed description of the S\&T activities (and the outcomes and links to site-wide assessments with the SAC and individual projects) is presented in Sections 2.0 and 4.0 of the roadmap.

\subsubsection{Inventory Technical Element}

The inventory technical element addresses the need for a mass balance-based inventory of contaminants in soil sites that can be used for site-wide assessments and core projects. The inventory element builds on existing information about the amount and nature of the Hanford Site inventory that already exists in different forms. Several systems (Tank Waste Information Network System, Waste Information Data System, and Solid Waste Information Tracking System) are used to track inventories at the Hanford Site. Based on past assessments, four problems were identified: 1) there are a large number of sites and contaminants, 2) inventory data that meet data quality requirements are not available for all of the sites and contaminants, 3) characterization to obtain these missing inventory data is expensive and time consuming, and 4) current approaches for inventory estimates introduce large uncertainty in sitewide and site-specific assessments. 
The S\&T Project is developing models and data that describe the estimates and uncertainty for:

- partitioning wastes in process streams that were discharged to soils

- estimating inventories for waste sites that operated for a short time (less than one year)

- estimating inventories for waste sites that operated over multiple years

- releasing contaminants from waste forms disposed of at the Hanford Site.

\subsubsection{Vadose Zone Technical Element}

The flux of contaminants through the vadose zone to the groundwater under varying geologic, hydrologic, and chemical conditions is key to making technically sound decisions regarding waste site characterization and remediation, e.g., for carbon tetrachloride and past single-shell tank (SST) leaks, and SST retrieval and closure. Because of environmental, safety, and health considerations associated with subsurface contamination and the unconsolidated and heterogeneous geology at the Hanford Site, the cost for characterization has been high, and characterization tools have not been available for collecting some types of field data. Therefore, the vadose zone technical element is focused on collecting data and information to improve the conceptual and numerical models that describe the location of contaminants today and to provide the basis for forecasting the release of contaminants to the vadose zone and the future movement of contaminants on both site-specific and site-wide scales. These forecasts provide the basis for planning site-characterization efforts. A key element of predicting future contaminant transport is the distribution of natural recharge. There is also a need for advanced characterization and monitoring tools to improve the detection and monitoring of non-gamma-emitting contaminants of concern in the vadose zone.

The S\&T Project is conducting field and laboratory studies and developing and applying advanced numerical models that:

- result in improved conceptual and numerical models of important aspects of contaminant behavior in the vadose zone

- include evaluations of water and contaminant movement at representative, contaminated, and uncontaminated field sites and targeted investigations to define controlling physical and chemical processes, including recharge, lateral spreading, and contaminant attenuation

- provide focused laboratory experiments on waste-sediment interactions and chemical transport and develop improved (multiphase reactive) transport models to forecast the future migration of contaminants and to influence remedial actions

- provide opportunities to deploy and test advanced characterization tools and methodologies to clearly identify mechanisms and processes that control the depth and extent of contaminant plumes in the Hanford Site vadose zone and to calibrate and refine predictive transport models.

\subsubsection{Groundwater Technical Element}

When the Integration Project was initiated, the understanding of the groundwater technical element was determined to be more mature than the understanding of other technical elements. However, the 
Integration Project identified gaps in knowledge, specifically in the groundwater-river interface, vadose zone-groundwater interface, and three-dimensional characterization at multiple scales.

The S\&T Project identified the need for and is conducting studies that provide:

- groundwater-river discharge studies to determine the location of contaminant releases and the estimation of contaminant flux to the Columbia River

- depth-discrete sampling at key locations to investigate interactions between the vadose zone and groundwater

- field-scale evaluation of the regional three-dimensional geometry of contaminant plumes

- multi-scale three-dimensional modeling based on objectives to be determined in concert with the requirements of site-wide assessments and individual project needs.

Except for the groundwater/river interface task of the S\&T Project, most of the investigations addressing this technical element are being done through the Groundwater Project.

\subsubsection{Columbia River Technical Element}

To conduct the site-wide system assessment of the potential impacts of alternative remedial actions on the Columbia River, an enhanced understanding of the river environment is needed. The assessment of the river needs to account for multiple contaminant inputs from sources, the transport and fate of those contaminants in the river environment (physical, chemical, and biological systems), and the potential impacts of those contaminants.

The S\&T Project identified the need for and is conducting studies that provide:

- enhanced conceptual models of the river, using new information and existing monitoring data from multiple agencies

- methods and data for characterizing the river and describing transfer factors and input parameters for transport and fate models

- enhanced understanding of the potential impacts of groundwater discharge to the river on affected biota, as well as confirming transport and fate predictions in the river.

\subsubsection{Risk Technical Element}

Past site-wide assessments of the impacts from contamination at the Hanford Site identified the need to reduce uncertainty in risk-assessment methodologies and data. The categories of risk important to decision making include ecological, human health, economic, and socio-cultural impacts. The missing data include biological uptake of selected Hanford contaminants, such as technetium-99, strontium-90, chromium, and iodine-129 as well as others. Human health includes consideration of exposure scenarios for specific groups and the transfer of contaminants through the food chain. Site-specific data for economic and socio-cultural risk assessments are limited. 
The S\&T Project identified the need for and is conducting studies that provide:

- data to reduce uncertainty in ecological risk assessment through measuring biological uptake of key contaminants by ecological resources

- data to facilitate realistic and comprehensive risks to humans from environmental exposures

- methods for economic-impact assessments based on realistic trigger mechanisms, regional economic activities, and estimation of economic benefit associated with specific natural resources

- conceptual models for inclusion of socio-cultural impacts in cumulative risk assessments.

\subsubsection{Remediation Technical Element}

The remediation technical element, being added to this revision of the roadmap, will address remediation of soil and groundwater at the Hanford Site contaminated with strontium-90, technetium-99, uranium, carbon tetrachloride, and chromium. An additional area of scope for the remediation element includes technical gaps and needs associated with surface barriers. The remediation technical element is important because some of the contamination problems that exist at the Hanford Site currently do not have cost-effective final remedial solutions. In addition, significant cost savings can potentially be realized by accelerating the characterization and remediation of subsurface contaminant plumes. Improved remediation technologies and strategies are needed for long-lived radionuclide and chemical contaminants that exist in the vadose zone and groundwater at the Hanford Site. The DOE EM OST and other Federal agencies have invested in remediation technologies that are applicable to the Hanford Site. Some of these technologies, e.g., surface barriers, in situ reduction oxidation (REDOX) manipulation, in situ gaseous reduction, are in various stages of demonstration and deployment at Hanford.

The S\&T Project identified the need for studies that provide:

- data and information on the feasibility of remediation approaches for strontium-90 at the 100-N Area, including monitored natural attenuation, phytoremediation, and methods for sequestering strontium-90 in the subsurface

- data and information on alternative technologies for remediating chromium in the vadose zone and groundwater, including the refinement of the in situ REDOX manipulation technology and bioremediation

- data and information on reduction and immobilization methods for technetium-99 and uranium

- characterization and remediation technologies for carbon tetrachloride in the vadose zone and groundwater

- technologies for cost-effective large-scale evaluation of surface barrier hydrologic performance and the feasibility of a modified Hanford Barrier that meets regulatory requirements.

\subsubsection{Monitoring Technical Element}

Environmental monitoring will be deployed long after Hanford Site closure. Cost-effective long-term monitoring technologies and strategies are needed for Hanford Site contaminants in air, soil, the vadose zone, groundwater, the Columbia River, and biota. 
The S\&T Project identified the need for studies that will:

- identify, develop, and deploy improved environmental monitoring technologies and strategies. 


\subsection{Implementation of the S\&T Roadmap}

Two types of research have been implemented through the S\&T roadmap. The first consists of shorter-term applied research supported through S\&T Project funding that will contribute to specific Groundwater Protection Program projects and has contributed to Integration Project milestones. The second consists of longer term (3 years) fundamental studies supported by the DOE EMSP Program through the FY99 call for proposals. Other activities funded by the DOE EM-50 OST and core projects also have contributed to the S\&T Project.

\subsection{Site-Directed S\&T Accomplishments}

The S\&T Project began implementing the roadmap in FY00, with a few key activities in inventory and vadose zone beginning in FY99. The tasks performed included activities to:

- revise the S\&T roadmap to include the Risk Technical Element, Rev. 1

- provide mass-balanced soil waste inventory to SAC, Rev. 0

- develop improved subsurface conceptual models of geochemical and hydrologic conditions and processes for the single-shell tank farm Waste Management Area (WMA) S-SX

- conduct multiphase reactive transport modeling to support process-level conceptual model development at WMA S-SX

- define the strategy and test plan, complete the field design, and conduct a vadose-zone transport field experiment at an existing test site

- select and apply advanced characterization technologies to the vadose-zone transport field study and evaluate their applicability to characterization and monitoring at the Hanford Site

- refine the conceptual model of the zone of groundwater/river interaction for input to SAC, Rev. 1.

During FY01 and FY02, efforts continued on the tasks identified above, and work was initiated to:

- develop improved conceptual and numerical models of geochemical and hydrologic conditions and important subsurface processes for WMA B-BX-BY

- complete field experiments at the vadose-zone transport field study site using high salt injection fluids

- initiate biological fate-and-transport experiments describing the uptake of technetium-99 by fish and aquatic plants.

Major accomplishments of the S\&T Project to date include:

- completing the development of the Soil Inventory Model (SIM) to derive waste inventories and uncertainties for contaminated soil sites in the 200 Areas (Simpson, Corbin, and Agnew 2001) (these results were used in the initial site-wide assessment with SAC [Bryce et al. 2002])

- incorporating research results from the S\&T Project and EMSP directly into the Field Investigation Report for the S-SX Tank Farm (S-SX FIR), a TPA-mandated milestone dealing with tank farm 
corrective actions (DOE 2002) (work is now underway focused on investigations of the B-BX-BY Tank Farm)

- completing field experiments in the 200-East Area with dilute and saline solutions and tracers, showing that subtle changes in sediment texture can induce lateral spreading of moisture plumes and contaminants in the vadose zone (Gee and Ward 2001) (these field experiments included EMSP contributions and evaluation of nine different geophysical characterization methods)

- completing the development of conceptual and numerical models of the groundwater/river interface at 100-H Area (the effort is now focused on developing models of other reactor areas)

- adding the risk assessment technical element to the S\&T Roadmap and completing biological fateand-transport experiments involving technetium-99 uptake in fish and an aquatic plant.

A major focus of the S\&T project was on fundamental research of mineralogy, geochemistry, and reactive transport modeling, as well as the determination of field hydrologic parameters to address specific issues with the S-SX Tank Farm. Laboratory experiments on S-SX Tank Farm sediments provided results that led to an understanding of complex relationships between sodium ion concentrations and the mobility of cesium-137 in the vadose zone. Other laboratory studies have led to the development of a plausible hypothesis to explain the apparent retardation of chromium(VI) in the Hanford sediments. Desorption kinetic studies with chromium- and cesium-contaminated sediments have produced releaserate models that can be used for defensible projections of the future mobility of these sorbed contaminants. Isotope geochemistry studies suggest that additional insight into multiple tank leak events can be developed by coupling Hanford irradiated fuel composition records with trace isotope analyses. Fluid flow, heat transport, and nonisothermal multiphase fluid flow and transport numerical modeling studies have provided insight into the impacts of high-heat tank waste storage and leakage on the vadosezone geochemical environment. Finally, large-scale field investigations provide a better understanding of realistic hydrologic parameters required for transport modeling studies. Results of the S-SX tank farm investigation, including S\&T contributions, are documented in the River Protection Project (RPP 2002a).

In particular, a key finding from the $\mathrm{S} \& \mathrm{~T}$ project is that cesium is quite mobile under high aqueous sodium conditions, e.g., the initial phase of the Tank SX-108 leak, but is highly retarded for low concentrations of sodium, e.g., the SX-115 leak. Thus, the observations that greatly contributed to the creation of the RCRA Corrective Action Program (the unexplained presence of a material far from its source, which was thought to be highly retarded in its movement) are now explained. Central to this explanation is the current belief that sodium concentrations in some of the leaked tank supernate, e.g., SX-108, were higher than originally thought. These concentrations may have exceeded $15 \mathrm{~mol} / \mathrm{L}$, a concentration that virtually eliminates the retardation of cesium. The high sodium concentrations, which resulted from the boiling and self-concentration of the wastes, were suggested by modeling and porewater characterization data from the slant borehole samples.

\subsection{EMSP Accomplishments}

Rev. 0 of the S\&T roadmap was used to influence the FY99 call for proposals issued by the DOE EMSP that was focused on vadose-zone science issues. Additionally, the S\&T Project provided a science plan specific to Hanford linked to the call that identified key scientific issues associated with the longterm migration behavior of high-level waste residuals in the vadose zone. As a result of this coordination, DOE received proposals in response to the call that were both relevant to and focused on specific Hanford 
Site scientific issues. The EMSP awarded 31 new grants from this call ( $\$ 25 \mathrm{M}$ in work scope over 3 years) that were directed at vadose-zone problems. The scope of the research portfolio includes, among others, the following topical areas:

- behavior of dense nonaqueous phase liquids (DNAPL) in the subsurface

- hydrophysical transport processes of high-level waste solutions in heterogeneous vadose-zone sediments

- geochemical reaction processes of high-level waste solutions and entrained contaminants in vadosezone sediments

- geologic controls on water/waste migration in the vadose zone and geophysical methods for in situ characterization.

When the EMSP selected the 31 grants, they also provided funding to the S\&T Project to facilitate interaction with the EMSP principal investigators and to incorporate their results into meaningful, impactful activities at the Hanford Site (EMSP Linkage Project). The Integration Project established and maintained linkages with the EMSP investigators through a series of three focused workshops that were held at the Environmental Molecular Science Laboratory at the Hanford Site. These workshops paired EMSP investigators with Hanford Site remediation contractors. EMSP investigators first presented their research plans, and in subsequent years, presented their evolving research results and their implications to Hanford. Site personnel, in turn, identified critical scientific issues and key information needs, updated yearly by results of field investigations of contaminated sites, and suggested minor modifications to research scope to enhance benefit. Considerable mutual understanding and collaboration developed between these parties over the 3-year period with the important result that many of the EMSP research results and findings are immediately applicable to issues resolution and technology needs at the site.

In addition to hosting the workshops, the S\&T Project provided contaminated and uncontaminated sediment samples to EMSP investigators and facilitated access to the Hanford Site to conduct research. Uncontaminated samples were obtained from the placement of new compliance-driven monitoring wells while contaminated samples were obtained from several different tank farms (S-SX, B-BX-BY), and pastpractice crib sites (TW-1/TW-2). These samples were carefully selected by S\&T Project personnel and tailored to the scope/hypotheses of the requesting EMSP project so that the results obtained with them would have maximal potential scientific and Site benefit. In select cases, funding from the EMSP Linkage Project was used to augment EMSP projects to perform specific, state-of-science analyses, consistent with project objectives and scope, on high-visibility Hanford samples. This approach was used to obtain sophisticated chemical speciation measurements of chromium (S-SX tank farm), uranium (B-BX-BY tank farm), and plutonium (TW-1/TW-2) at DOE user facilities as needed for determining corrective/remedial actions.

EMSP principal investigators also participated directly in several field-transport experiments performed at the S\&T Project's Vadose Zone Test Facility. In these studies coordinated by S\&T Project staff, dilute and saline fluids have been injected into the vadose zone to test hypotheses on geologic controls on unsaturated fluid flow. Moisture and tracer plumes have been characterized and tracked using different subsurface geophysical methods offered by EMSP investigators and other participants. A reactive tracer experiment is currently being planned. 
To large degree, the full impact of the EMSP-Hanford Site partnership is emerging as the FY99 EMSP projects complete their 3-year term, and results are published and delivered to users and the scientific community in "final" form. The following example scientific benefits have already been realized:

- EMSP projects have performed experiments and sophisticated analyses and developed new models that have improved Hanford's ability to describe past cesium-137 and chromium migration events in the vadose zone beneath leaked single-shell tanks as well as to predict future transport as required for remedial assessment.

- EMSP investigated the interactions of highly basic REDOX waste simulants with S-SX sediments. The results of these investigations showed that significant mineral alteration and precipitation has occurred.

- EMSP investigators developed a multi-site cation exchange model that captures many of the chemical effects responsible for the dependence of the cesium-137 distribution coefficient on competing cation and cesium concentrations.

- EMSP investigators performed X-ray absorption (XAS) measurements to demonstrate that chromium existed in two valence states (III, VI). The XAS measurements showed that about 30 to $60 \%$ of the chromium was immobilized as chromium (III) precipitate, with the remainder as water-soluble chromium (VI).

- New conceptual models have been developed through experimentation that describe the complex geochemical and hydrologic behavior of high-level waste solutions in the vadose zone. The effects of high salt and caustic are now sufficiently understood to speculate on migration behavior of hot, dense, high-level waste supernatant in the Hanford vadose zone, and to develop improved reaction/transport models.

- A collaborative team involving EMSP investigators has performed field experiments at the Hanford Site that have shown that subtle changes in sediment texture can induce lateral spreading of moisture plumes and contaminants in the vadose zone. These observations have provided a conceptual framework to interpret the complex contaminant-distribution patterns noted in the tank farms, and the impetus to upgrade vadose zone transport models to incorporate this key effect.

The details of these general findings have been incorporated directly into the recently completed Field Investigation Report for the S-SX Tank Farm, as previously described. This is the first time that EMSP research has been used in direct support of a Hanford regulatory milestone. The Integration Project is incorporating other scientific contributions of the EMSP research contributing to the Field Investigation Report for the B-BX-BY Tank Farm currently being assembled. The collective scientific accomplishments of the FY 1999 EMSP Vadose Zone Projects and the implications and utility of this research to the Hanford site will be summarized in report form as an activity within the EMSP Linkage Project.

Other EMSP projects are focused on research on the controls of contaminant release from tank residual wastes and transport through the vadose zone. Specific EMSP projects are evaluating physiochemical processes controlling tank residual source terms, technetium chemistry in high level waste and the role of complexants, and contaminant fate and transport in tank farm vadose zones. The 
DOE ORP S\&T roadmap (DOE 2002) documents tank-farm gaps and needs and the research required to fill those gaps.

\subsection{Science and Technology Linkages with EM-40 and EM-50}

A number of technology-development activities are being conducted at the Hanford Site. These development activities are intended to improve the technical basis and reduce the costs of waste management, environmental protection, and site restoration. Technology-development activities outside of the S\&T Project are being conducted at the Hanford Site. Many of these activities are intended to improve the technical basis and reduce the costs of waste management, environmental protection, and site restoration.

Surface-barrier monitoring and testing continues at the Hanford Site. A 4-year treatability test, which began in 1994, was successfully completed in 1998 for the Hanford Prototype Barrier Project. The project was designed to evaluate and document surface-barrier constructability, construction costs, and physical and hydrologic performance over the 216-B-57 Crib in the 200 East Area. Treatability tests were conducted in two phases: Phase I included the design and construction of the prototype and was completed in 1994, and Phase II included the 4-year testing and monitoring effort. The function of the surface barrier is to assure that buried wastes are contained and protected from the infiltration of water, surface erosion, and bio intrusion. Testing was completed for water balance within the barrier under conditions of ambient and extreme precipitation, surface wind and water erosion, stability of the barrier foundation, surface and rip-rap side slope, surface vegetation dynamics, and animal intrusion. During the treatability test period, results demonstrated the ease of construction with standard equipment, all design performance criteria were met or exceeded, and the design components were highly effective (DOE-RL 1999b). Measuring and testing of the surface barrier continued into FY02 at a reduced level to collect longer term data.

In response to a request by the DOE Office of River Protection, the DOE-EM TechCon and ITRD programs conducted a 2-day forum during May 1999 to seek assistance in reducing water infiltration around Hanford Site single-shell tanks. The purpose of the forum was to identify a range of commercially available alternatives and provide opportunity for interactions between site contractors, vendors, scientists, and stakeholders. Technical sessions were held on the following areas of interest: moisture characterization and monitoring, structures, surface covers, and near-surface barriers. Commercial vendors with experience in monitoring subsurface moisture and controlling surface-infiltration of water into radioactively contaminated soils participated in the forum. The team performed an analysis on the ability of the different alternatives presented to meet Hanford Site requirements. The conclusions and recommendations from the meeting were as follows:

- Significant commercial capabilities and relevant experience were available for each of the major areas of interest.

- The technologies are available for deployment in less than 6 months following receipt of an order by the vendors.

- Moisture monitoring capabilities are compatible with conditions that exist at the Hanford Site, and monitoring could be considered for mitigating characterization uncertainty in the short term. 
- There is a strong bias for deployment, rather than demonstration; available technologies were considered to be adequate.

- Time is of the essence in acting to minimize water infiltration, and the information presented suggested significant cost and schedule savings associated with early action.

- There is no single technology/solution to address all of the issues that exist; a combination of alternatives that were presented will be suitable for minimizing water infiltration under tank farm conditions.

- Deployment of technologies should be done in a phased approach; the first application should be in a tank farm known to have contaminant migration.

In the 100-D Area, implementation of the in situ REDOX manipulation technology is being completed to remediate hexavalent chromium contamination in the groundwater. The National Energy Research Laboratory granted Applied Research Associates a grant to develop an Enhanced Access Penetration System (EAPS) that can be used to extend the depth and geology range over which a cone penetrometer system can be used. The design will have two possible modes of operation-either direct penetration with rotary percussion drilling or direct penetration with laser drilling enhancement. The system is intended to enable the cone-penetrometer system to penetrate difficult geologic materials such as cemented caliche and cobbles. The system prototype is scheduled for demonstration near the 200 West Area of the Hanford site close to the carbon tetrachloride plume in the fall of 2002.

\subsection{Core Project Science and Technology Contributions}

In addition to S\&T accomplished through the roadmap, the Integration Project (now the Groundwater Protection Program) and core projects are driving technology advancements. S\&T development projects resulting from this integrated approach include

- technologies and equipment to drill a slant borehole and collect samples, minimizing the impacts of contamination drag-down developed by the Tank Farm Vadose Zone Project

- development of the pressurized unsaturated flow (PUF) test to mimic conditions of the immobilized low activity waste (ILAW) disposal facility, where moisture contents as low as $5 \%$ make measurements difficult (this apparatus makes measurement of the performance of different glass compositions possible under conditions reflecting the disposal facility)

- drilling ILAW boreholes to collect minimally disturbed vadose zone samples, resulting in revision of the understanding of the Hanford formation (previously, the entire Hanford formation was thought to consist of glacial flood sediments deposited less than 1 million years ago; the new geologic interpretation of the Hanford formation suggests that the oldest Missoula flood was 2 million years ago)

- performing experiments to determine geochemical and hydrologic parameters governing flow and transport through ILAW glass rubble and host materials, with both conservative and reactive tracers (results show that backfilled fines in the glass rubble form pockets of immobile or slowly moving water that slows fluid flow-and-contaminant transport)

- using Monte Carlo simulations to obtain effective (upscaled) flow-and-transport properties to represent a heterogeneous unsaturated medium by its homogeneous equivalent. 
The DOE Office of River Protection completed a field test to evaluate methods for detection of tank leaks. During July and August, 2001, six "ex-tank" leak detection technologies were deployed at the Hanford Mock Tank Site in a Tank Leak Detection Demonstration. These technologies included five geophysical methods and a subsurface air flow and extraction (SAFE) method. Results documented in Barnett, Gee, and Sweeney (2002) and Cameron et al. (2002) demonstrated that small volumes of tank leaks, 378.5 to 1893 L (100 to 500 gal), could be detected. Several of the geophysical methods (Electrical Resistance Tomography and High Resolution Steel Casing Resistivity Technology) were selected for further evaluation (RPP 2002b).

\subsection{National Research Council Review}

In August, 2001, a National Academy of Sciences/National Research Council committee completed review of the S\&T Project (National Research Council 2001). The committee evaluated the technical merit of the S\&T work to be carried out, including its likely contribution to advancing the state of scientific knowledge, the relevance and timeliness for remediation decisions, and the potential applicability to other DOE Sites.

The committee reviewed in detail the S\&T roadmap, the work that is underway by the S\&T Project, and progress by EMSP investigators. The committee also reviewed the System Assessment Capability to identify important knowledge gaps that should be addressed by S\&T.

The committee concluded that there is a long-term and continuing need for S\&T to support cleanup and stewardship of the Hanford Site, and that given the technical and organizational complexity of the task, the S\&T Project has made a good start in creating an S\&T roadmap, defining and initiating work scope, and fulfilling the promise of its mission.

Technical Merit. The committee concluded that the work to be carried out under the S\&T Project is technically meritorious and is likely, at least in some cases, to make important contributions to advancing scientific knowledge. They qualified this conclusion because they felt that documentation on most of the S\&T activities was insufficient to evaluate in detail the precise scope of work to be done or its technical merit. They noted that the EMSP projects were well documented as well as activities under the Vadose Zone Technical Element, particularly the vadose zone transport field studies.

The committee recommended two activities for the S\&T Project to improve technical merit:

- develop and implement guidelines for documenting the objectives, study design and work plans, products, schedules, and costs for S\&T activities

- implement peer review to assist with prioritization and selection of S\&T activities and to track progress for multiyear activities.

Relevance and Timeliness for Remediation Decisions. The committee stated that the S\&T portfolio blends well with the activities and needs of the core projects and is broadly relevant to remediation decisions to be made at the Site. They state that the S\&T Project lacks a systematic framework for identifying and addressing knowledge gaps that impede progress and that this framework will become more important as remediation proceeds. They suggest that the SAC and peer review may be useful tools to help set S\&T priorities. 
Specific recommendations to improve relevance and timeliness of the S\&T work were for the Integration Project to:

- develop and implement a system for prioritizing S\&T activities to provide information that Hanford Site management will need to make sound cleanup and stewardship decisions

- perform a system-based analysis of its funding needs with the help of EM, once it develops the prioritization process recommended above

- review its organization to assure that ownership, authority, and accountability for the S\&T Project are clearly defined and assigned. They state that given the number of organizations involved in S\&T and cleanup activities at the Hanford Site, help from DOE management above the level of the Integration Project (Groundwater Protection Program) may be needed.

Potential Applicability to Other DOE Sites. The committee concluded that some of the planned S\&T results will potentially be applicable to other DOE sites, specifically to other contaminated sites in arid regions. They stated that because development of the S\&T roadmap involved experts from other DOE national laboratories and other sites, the current and planned S\&T activities address first-order scientific questions. They commented that the planned work and activities that they recommended could lead to technologies that may be transferable.

The committee's review of the technical elements identified several activities that are not now being addressed, but that the committee feels should be a high priority:

- developing cost-effective strategies and methods for characterizing contaminant distributions and subsurface properties

- developing advanced monitoring methods for the vadose zone and Columbia River

- developing improved barrier technologies, including surface barriers, vertical and inclined cutoff barriers, and reactive barriers

- evaluating the probabilities and consequences of extreme events, particularly glacial flooding.

They also made observations of the existing S\&T investments:

- Planned work on upscaling identified under the Vadose Zone Technical Element should be initiated as soon as possible and could be important in the design of vadose zone transport field studies.

- Most of the planned work on generic issues in the Risk Assessment Technical Element should not be funded by the Integration project because it is more appropriate for national research programs in DOE and other federal agencies.

The Integration Project reviewed the National Research Council's committee's recommendations and developed initial responses to the recommendations. The Integration Project is taking the following actions to address recommendations for process improvements:

- External peer review will be incorporated into the project during FY03 to evaluate priorities of S\&T research activities. 
- A tiered approach will be used for peer review of specific technical elements and individual S\&T tasks, including the Groundwater Protection Program Expert Panel and other external review panels, starting in FY03.

- During FY03, the S\&T Project will develop and implement guidelines for individual technical task plans that capture the objectives, study design, technical approach, products, and schedules, with detail commensurate with the level of funding for the activity.

The S\&T Project is taking the following actions to address technical recommendations raised by the committee:

- The S\&T Project has evaluated nine different vadose-zone characterization methods as part of its Vadose Zone Transport Field Studies, and several of these technologies are continuing to be evaluated as part of the DOE ORP Leak Detection, Mitigation, and Monitoring Project.

- The S\&T Project is updating the roadmap in this revision to include the remediation technical element. The roadmap will be updated to include the monitoring technical element in FY04.

- As requirements to analyze the effects of extreme events are established for the System Assessment Capability, the results of previous studies will be used to determine if additional S\&T investments are needed.

- The 200 Area Remedial Action Project is developing an overall strategy to characterize and remediate carbon tetrachloride in the vadose zone and groundwater, including scientific contributions from the S\&T Project. Carbon tetrachloride acceleration is a target for an OST proposal for accelerating the Hanford Site baseline.

- Upscaling has been factored into design of the Vadose Zone Transport Field Study experiments, and inverse modeling is being applied to investigate scaling issues and uncertainty. The more general aspects of this comment are being evaluated during this revision of the roadmap to determine its applicability beyond the Vadose Zone Transport Field Studies to other activities and their linkage to site-wide modeling efforts.

- The Risk Assessment Technical Element will focus work on Hanford-specific risk-assessment data that are useful to the site-wide and site-specific assessments.

- The S\&T project is coordinating with ORP to integrate S\&T planning.

The S\&T Project is taking the following actions to address recommendations for improvements to the System Assessment Capability:

- The S\&T Project is working with core projects to emphasize field characterization where distributions of hydraulic and contaminant concentrations in the vadose zone are being generated. This emphasis on field characterization will continue into the future.

- The Vadose Zone Transport Field Study has developed three-dimensional data sets of hydraulic properties, moisture contents, and tracer distributions in the vadose zone from the first two years of field experiments, and field tests are being conducted at a second field test site in FY02 and FY03.

- Exposure pathways other than groundwater, consideration of a longer analysis time frame, the effects of removing the dams on the Columbia River, and extreme events such as fires, floods, and 
earthquakes are being evaluated as requirements for the site-wide assessments with the System Assessment Capability. 


\subsection{Innovative Treatment Remediation Demonstration Projects}

There are two projects where DOE Richland Operations requested technical assistance from the DOE OST (EM-50) ITRD program to evaluate innovative technologies to address subsurface contamination. The first project, initiated in 1998, addressed strontium-90 contamination in the vadose zone and groundwater at the 100-N Area. The second project, initiated in 1999, addressed carbon tetrachloride contamination in the vadose zone and groundwater at the 200-West Area.

\subsection{0-N ITRD Project}

In response to the DOE Richland Operations request for technical assistance, the ITRD Program formed and coordinated a Technical Advisory Group (TAG) with technology experts and participants from government, industry, and regulatory groups. The focus of the group was to identify technologies that could improve the current pump-and-treat baseline for groundwater remediation at 100-N Area. The TAG evaluated approximately 50 technologies, including in situ, ex situ, and enabling technologies, for possible implementation. Through the ITRD process, five potentially useful technologies were identified: a clinoptilolite permeable barrier, a sheet pile/cryogenic impermeable barrier, monitored natural attenuation, phytoremediation, and soil flushing. The technologies suggested are generally lower in cost, generate less waste, or have greater maturity than competing technologies for site-specific contaminants.

The TAG commissioned four studies to fill knowledge and data gaps. These studies included a Bank Stability study (BHI 2000), a groundwater-river interaction modeling study, ${ }^{(a)}$ a strontium-stabilization study, ${ }^{(b)}$ and a soil flushing study (MSE 1999). Detailed engineering evaluations were conducted for: monitored natural attenuation, ${ }^{(c)}$ phytoremediation, a clinoptilolite treatment wall, and an impermeable sheet pile/cryogenic barrier wall. Phase II studies were carried out to provide detailed designs of a soil flushing system (MSE 2000) and to model the transport of strontium under transient conditions at the river-aquifer interface. The TAG also requested cost estimates for pilot-scale studies of soil flushing and strontium-stabilization to answer concerns about the feasibility of implementation. Due to the rapid technology development in the field, this report did not present a state-of-the-art evaluation for 2002.

Scenarios consisting of combinations of the candidate technologies for remediation of the 100-N Area were formulated, and a preliminary engineering cost analysis of the remedial scenarios was conducted. ${ }^{(\mathrm{d})}$

Based on this evaluation, the TAG recommended that the following remediation scenarios be evaluated in more detail:

- monitored natural attenuation

(a) Hydrogeologic, Inc. 1999. Groundwater-River Interaction in the Near-River Environment at the 100-N Area. (Unpublished white paper for the ITRD Program) Rev. 0, Hydrogeologic, Inc., Herndon, VA.

(b) TE Moody. 1999. The Use of Phosphatic Materials for Hanford N-Springs Strontium-90 Stabilization, Phase I. (Unpublished white paper for the ITRD Program) M Pulse Technology, Richland, WA.

(c) Kelley MJ. 2001. Natural Attenuation for the Hanford 100-N Area Site. Unpublished white paper for the Innovative Treatment and Remediation Demonstration Program, Rev. 0, Sandia National Laboratories, Albuquerque, NM.

(d) Studer 2001. Technical Memorandum-Preliminary Engineering Cost Analysis of Hanford 100-N Area Remediation Scenarios. (Unpublished white paper for the ITRD Program). 
- clinoptilolite barrier with monitored natural attenuation

- clinoptilolite barrier with phytoremediation on the river side of the barrier

- sheet pile/cryogenic impermeable barrier with monitored natural attenuation

- sheet pile/cryogenic impermeable barrier with phytoremediation on the river side of the barrier and soil flushing on the inland side.

Neither soil flushing nor the constructed barriers will eliminate near-term releases from the riverbank to the Columbia River. Groundwater flow and transport modeling ${ }^{(a)}$ indicates that the total release to the Columbia River over the full length of the contaminant zone during 2 half-lives (about 60 years) would be 4.92 to $6.15 \mathrm{Ci}$. This amount of release may not present a risk to human health or the environment. A risk analysis could be performed in collaboration with the regulators to determine if this level of release is acceptable. If this is the case, then monitored natural attenuation, or alternative concentration limits, may be a sufficient remedial option.

Alternatively, additional studies of phytoremediation could provide confidence that this technology can be used to control releases from the riverbank. The final remedy should be developed in consultation with the regulators and stakeholders, and alternate combinations of the technologies may be the solution.

The results of the ITRD project for 100-N strontium-90 are documented in ITRD (2002a).

\subsection{Area Carbon Tetrachloride Evaluation}

In response to the request by DOE Richland Operations, the ITRD program provided technical support to determine the state of the technology for characterization and remediation of the Hanford 200 West Site where carbon tetrachloride contaminates groundwater and the vadose zone. A TAG was formed for this project as well to identify and assess technologies capable of enhancing and accelerating the remediation of carbon tetrachloride at the Hanford 200 West Site.

Site cleanup of carbon tetrachloride is complicated by the presence of a relatively low-permeability layer at a depth of $35 \mathrm{~m}(115 \mathrm{ft})$, where DNAPL may have accumulated, and by the depth to the water table $(76.2 \mathrm{~m}[250 \mathrm{ft}])$. These features, and the presence of radioactive soil contamination within the soil cribs, result in high well-installation costs. Early in the evaluation process, it was recognized that the location of the DNAPL source must be defined and its volume estimated before treatment technologies could be evaluated. This shifted some of the focus to characterization and access technologies; however, the selection of treatment technology must be integrated into a cost-effective strategy.

(a) Hydrogeologic, Inc. 1999. Groundwater-River Interaction in the Near-River Environment at the 100-N Area, unpublished white paper for the Innovative Treatment and Remediation Demonstration Program, Rev. 0, Hydrogeologic, Inc., Herndon, VA.

Hydrogeologic, Inc. 2000. Strontium-90 Transport in the Near-River Environment at the 100-N Area, unpublished white paper for the Innovative Treatment and Remediation Demonstration Program, Rev. 0, Hydrogeologic, Inc., Herndon, VA. 
A technology advisory group developed a project plan that includes the following activities:

- initial review of potential remediation technologies (complete)

- groundwater modeling of the carbon tetrachloride plume (in progress)

- identification of carbon tetrachloride DNAPL in the vadose zone and groundwater

- vadose-zone modeling of the carbon tetrachloride plume

- remediation alternative selection and recommendations for treatability studies

- carrying out of treatability studies

- final recommendation for remediation.

The technical advisory group identified and reviewed approximately 30 technologies they considered applicable to enhance the remediation of the carbon tetrachloride contamination. Categories of technologies they considered included in situ treatment of contaminated groundwater, in situ treatment of contaminated low-permeability sediments, and in situ treatment of high-permeability sediments. Issues considered in evaluating the technologies included implementation costs and ease of implementation, technology maturity, life-cycle costs and overall cost-effectiveness, ability to reduce carbon tetrachloride to regulatory levels at the points of compliance, compatibility with existing site constraints and existing treatment systems, stakeholder considerations, and regulatory permitting issues. The general maturity and cost-and-performance characteristics were reviewed as they apply to the 200 West Area. Based on this information, the most promising technologies will be further assessed with engineering evaluations conducted in collaboration with several technology vendors.

The advisory group suggested additional modeling and characterization activities to assist in developing a final recommendation for implementing a remediation strategy for the carbon tetrachloride plume. This forward path for the ITRD project provides opportunity for S\&T contributions. EMSP projects 70012, 70035, 70050, 70052, and 70063 awarded in FY99 may contribute S\&T results for the carbon tetrachloride problem. In addition, previous EMSP projects and those being considered for follow-on work may also contribute to the overall strategy for characterization and remediation of the carbon tetrachloride plume.

The results of the ITRD project for 200-West carbon tetrachloride are documented in ITRD (2002b). 


\subsection{Schedule of Science and Technology Activities and Outcomes}

This section presents information on the scope and schedule of activities and outcomes, along with linkages to the core projects. These linkages are shown in Figure 4.1 and Table 4.1 through Table 4.4. The schedule for key S\&T outcomes has been linked to site-wide assessments with the SAC and core project schedules. Figure 4.1 presents a summary-level graphic presentation of the S\&T activities, which are organized into categories of inventory, subsurface transport, Columbia River and risk, and remediation.

The information shown in Figure 4.1 includes the S\&T products through identification numbers that correspond to an explanation of scope and outcome in Table 4.1 through Table 4.4. Figure 4.1 also includes schedule and linkages of the products to the site-wide assessments and core projects that are shown by "down triangles" and "up triangles," respectively. Within each of these symbols, numbers are provided to link back to Table 4.1 through Table 4.4. The products numbered 1 through 8 in the "Inventory" section of Figure 4.1 correspond to identification numbers Inv-1 through Inv-8 in Table 4.1. Likewise, products numbered 1 through 24 in the section of Figure 4.1 labeled "Subsurface Transport" correspond to identification numbers ST-1 through ST-24 in Table 4.2. Products numbered 1 through 12 in the section of Figure 4.1 labeled "Columbia River and Risk" correspond to identification numbers CRR-1 through CRR-12 in Table 4.3. Products labeled 1 through 20 in the section of Figure 4.1 labeled "Remediation" correspond to identification numbers Rem-1 through Rem-20 in Table 4.4. A line is shown for the monitoring technical element. These technical elements will be expanded during a planned revision of the roadmap in FY03.

The products are also colored in Figure 4.1 to indicate project leads. Red coloration refers to an S\&T activity that will be carried out through a core project. An example is Inv-5, involving scope to perform bench-scale experiments to determine the composition of waste streams from specific chemical processing steps followed at the Hanford Site. Blue coloration refers to an S\&T activity that is led predominantly through DOE national S\&T programs such as EMSP or NABIR. Green coloration refers to an S\&T activity that is leveraged with a core project activity. An example is the field investigations of representative sites, e.g., ST-15, being conducted jointly with the Tank Farm Vadose Zone Project and the S\&T component of the Integration Project to perform an assessment of past tank leaks at the T-TX-TY Tank Farm. The Tank Farm Vadose Zone Project is conducting field characterization in the T-TX-TY Tank Farm and other tank farms needed to meet data quality objectives for corrective measures of these facilities per Resource Conservation and Recovery Act of 1976 (RCRA) requirements for treatment, storage, and disposal facilities. The Integration Project S\&T component is conducting analyses on samples taken by RPP from boreholes in the contaminated vadose zone. Both projects work together to interpret the data, develop conceptual models, and provide data to their respective users and decision makers.

Table 4.1 through Table 4.4 contain brief descriptions of the activities in Figure 4.1. These brief descriptions will be developed into detailed project plans annually during the detailed work planning process. The product identification numbers shown in Figure 4.1, e.g., Inv-1, ST-1, correspond directly to the identification numbers in Table 4.1 and Table 4.2. For each identification number, the following information is provided in Table 4.1 and Table 4.2 : 
- Id No. to identify the specific S\&T activity in the roadmap

- S\&T Activity within the technical element (broad categories of activities within each technical element)

- Descriptive Title unique for each product shown by identification number in Figure 4.1

- Brief Scope and Outcome description for each product shown in Figure 4.1, corresponding to the product identification number, e.g., Inv-1, etc.

- Hanford Site PBS (Project Baseline Summary) number associated with the S\&T work scope

- Interacts With to identify the projects for which integration or coordination is needed to conduct the activity and generate the desired product

- Product To to identify the recipient (or customer) for the product

- Desired Start Date of S\&T Activity to identify the date that startup is needed for the overall activity within each technical element to meet project schedules

- Product Delivery Date to identify when the S\&T product is needed, assuming the startup date is met, in accordance with the established project schedules. 
Applied Science and Technology Schedule, Logic, and Lineages

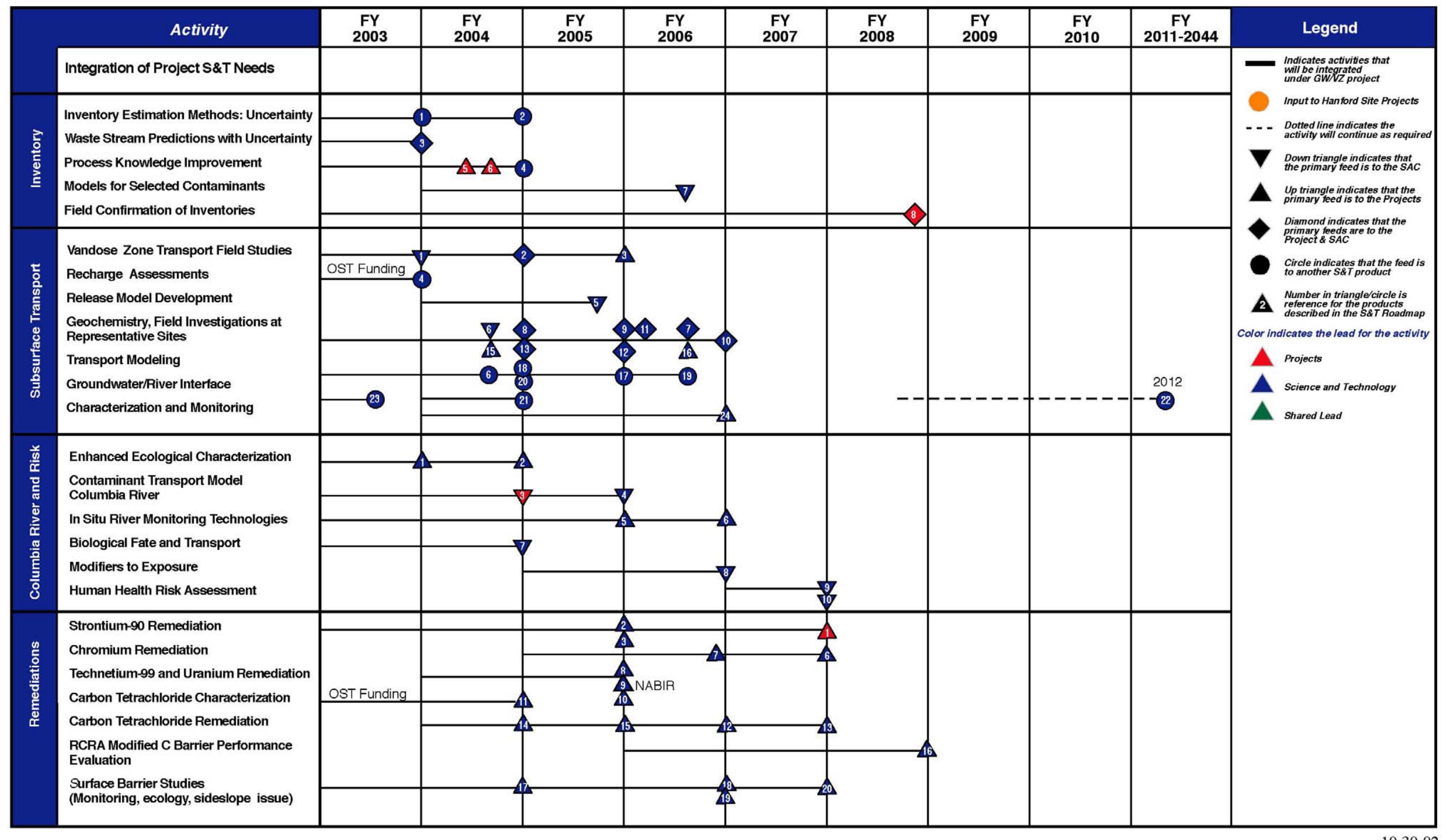

Figure 4.1. Applied Science and Technology Schedule, Logic, and Linkages 
Table 4.1. S\&T Schedule and Products for Inventory Technical Element

\begin{tabular}{|c|c|c|c|c|c|c|c|c|}
\hline Id No. & S\&T Activity & $\begin{array}{c}\text { Descriptive } \\
\text { Title }\end{array}$ & Brief Scope and Outcome & Hanford Site PBS & Interacts With & Product To & $\begin{array}{l}\text { Desired } \\
\text { Start } \\
\text { Date of } \\
\text { S\&T } \\
\text { Activity }\end{array}$ & $\begin{array}{l}\text { Product } \\
\text { Delivery } \\
\text { Date }\end{array}$ \\
\hline Inv-1 & $\begin{array}{l}\text { Inventory } \\
\text { Estimation } \\
\text { Methods: } \\
\text { Uncertainty }\end{array}$ & \begin{tabular}{|l|} 
Developing \\
Global \\
Uncertainty \\
Estimates for \\
Eras of Hanford \\
Site Operation \\
\\
\end{tabular} & $\begin{array}{l}\text { The scope of this activity is to develop and } \\
\text { publish defensible methods used for } \\
\text { quantifying the uncertainty associated } \\
\text { with inventory estimates and model } \\
\text { predictions associated with different eras } \\
\text { of Hanford Site operation, including 1944- } \\
1968 \text { when fewer records were } \\
\text { maintained; 1969-1988 when transuranic } \\
\text { (TRU) waste was first defined and records } \\
\text { on special nuclear material (SNM) and } \\
\text { nuclear material (NM) were mandated; } \\
\text { post } 1988 \text { when DOE Orders were } \\
\text { established for the storage and disposal of } \\
\text { wastes at DOE sites. Outcome is a better } \\
\text { definition of the levels of uncertainty } \\
\text { associated with higher-risk contaminants } \\
\text { in waste streams, waste forms, and past } \\
\text { disposals and discharges. }\end{array}$ & Central Plateau & $\begin{array}{l}\text { COS* and SAC; Tank } \\
\text { Farm Vadose Zone, } \\
200 \text { Area Remedial } \\
\text { Action } \\
\\
* \text { COS }= \\
\text { Characterization of } \\
\text { Systems }\end{array}$ & COS and SAC & $10 / 2$ & $9 / 03$ \\
\hline Inv-2 & $\begin{array}{l}\text { Uncertainty } \\
\text { Propagation }\end{array}$ & $\begin{array}{l}\text { Uncertainty } \\
\text { Propagation } \\
\text { within } \\
\text { ORIGEN2 } \\
\text { application to } \\
\text { Hanford fuels }\end{array}$ & $\begin{array}{l}\text { The scope of this activity is to develop a } \\
\text { defensible analysis of the uncertainty } \\
\text { associated with the total inventory of } \\
\text { radionuclides in fuel irradiated at the } \\
\text { Hanford Site in eight single-pass reactors } \\
\text { and the N-reactor. }\end{array}$ & Central Plateau & $\begin{array}{l}\text { COS and SAC; } \\
\text { BBI/HTWOS/HDW*; } \\
\text { BNI G2 } \\
\text { *HDW = Hanford } \\
\text { Defined Waste }\end{array}$ & COS and SAC & $10 / 03$ & 9/04 \\
\hline Inv-3 & $\begin{array}{l}\text { Waste Stream } \\
\text { Predictions } \\
\text { including } \\
\text { Uncertainty }\end{array}$ & \begin{tabular}{|l|} 
Second \\
Generation Soil \\
Inventory \\
Model (SIM) \\
\\
\end{tabular} & $\begin{array}{l}\text { The scope of this activity is to develop and } \\
\text { document the next generation SIM to } \\
\text { provide improved synthesis of process } \\
\text { knowledge, waste-stream characterization, } \\
\text { and field observations of waste-stream } \\
\text { byproducts in the vadose zone and } \\
\text { groundwater to estimate uncertain } \\
\text { inventories for unreported radionuclides } \\
\text { and chemicals in waste sites that operated } \\
\text { multiple years. }\end{array}$ & Central Plateau & $\begin{array}{l}\text { COS and SAC } \\
\text { activities; Tank Farm } \\
\text { Vadose Zone and } 200 \\
\text { Area Remedial Action }\end{array}$ & $\begin{array}{l}\text { COS and SAC, } 200 \\
\text { Area Remedial } \\
\text { Action Project, } \\
\text { Tank Farm Vadose } \\
\text { Zone Project }\end{array}$ & $3 / 02$ & $9 / 03$ \\
\hline
\end{tabular}


Table 4.1 (Contd)

\begin{tabular}{|c|c|c|c|c|c|c|c|c|}
\hline Id No. & S\&T Activity & $\begin{array}{l}\text { Descriptive } \\
\text { Title }\end{array}$ & Brief Scope and Outcome & Hanford Site PBS & Interacts With & Product To & $\begin{array}{c}\text { Desired } \\
\text { Start } \\
\text { Date of } \\
\text { S\&T } \\
\text { Activity }\end{array}$ & $\begin{array}{c}\text { Product } \\
\text { Delivery } \\
\text { Date }\end{array}$ \\
\hline Inv-4 & \begin{tabular}{|l|} 
Process \\
Knowledge \\
Improvement
\end{tabular} & \begin{tabular}{|l|} 
Process \\
Knowledge \\
Improvement \\
for Key \\
Radionuclides
\end{tabular} & $\begin{array}{l}\text { The scope of this activity is to develop } \\
\text { scientifically defensible process } \\
\text { knowledge regarding the movement of } \\
\text { key contaminants through chemical } \\
\text { separation plants, tank-waste storage, and } \\
\text { disposal facilities. Examples include } \\
\text { carbon-14, tritium, technetium- } 99 \text {, iodine- } \\
129 \text {, and uranium. The outcome will be } \\
\text { more credible predictions of the fate of } \\
\text { key contaminants. }\end{array}$ & Central Plateau & $\begin{array}{l}\text { COS and SAC; Tank } \\
\text { Farm Vadose Zone; } \\
\text { BBI/HTWOS/HDW; } \\
\text { BNI G2 }\end{array}$ & COS and SAC & $10 / 03$ & $9 / 04$ \\
\hline Inv-5 & $\begin{array}{l}\text { Waste Stream } \\
\text { Composition }\end{array}$ & $\begin{array}{l}\text { Bench-scale } \\
\text { experiments } \\
\text { defining the } \\
\text { waste-stream } \\
\text { composition of } \\
\text { chemical- } \\
\text { separation } \\
\text { plants }\end{array}$ & $\begin{array}{l}\text { The scope of this activity is to conduct } \\
\text { experiments that distinguish between } \\
\text { alternative hypotheses regarding the } \\
\text { composition of waste streams from } \\
\text { specific chemical processing steps or } \\
\text { reactions. Focus will be on the presence } \\
\text { and concentrations of higher-risk } \\
\text { contaminants, including carbon-14, } \\
\text { technetium- } 99 \text {, iodine-129, and uranium. }\end{array}$ & Central Plateau & $\begin{array}{l}\text { Tank Farm Vadose } \\
\text { Zone Project (Lead) }\end{array}$ & $\begin{array}{l}\text { COS and SAC; } \\
\text { BBI/HTWOS/HDW; } \\
\text { BHI G2 }\end{array}$ & $10 / 02$ & 2/04 \\
\hline Inv-6 & $\begin{array}{l}\text { High Level } \\
\text { Tank Waste } \\
\text { Inventory }\end{array}$ & \begin{tabular}{|l} 
Technetium-99 \\
inventory in \\
tanks
\end{tabular} & $\begin{array}{l}\text { The scope of this activity is to estimate } \\
\text { the volume and waste composition of } \\
\text { technetium-99 (and other key } \\
\text { radionuclides such as iodine-129 and } \\
\text { uranium) in high-level waste tanks using } \\
\text { process history and laboratory } \\
\text { measurements of tank samples. }\end{array}$ & Central Plateau & $\begin{array}{l}\text { Tank Farm Vadose } \\
\text { Zone Project (Lead) }\end{array}$ & $\begin{array}{l}\text { Accelerated Tank } \\
\text { Closure } \\
\text { Demonstration }\end{array}$ & $10 / 02$ & 6/04 \\
\hline Inv-7 & \begin{tabular}{|l|} 
Models for \\
Selected \\
Contaminants
\end{tabular} & \begin{tabular}{|l|} 
Consistent \\
holistic \\
inventory \\
estimates for \\
key \\
contaminants \\
\end{tabular} & $\begin{array}{l}\text { The scope of this activity is to develop } \\
\text { consistent, holistic inventory estimates for } \\
\text { key contaminants of concern for the site } \\
\text { assessments using SAC. These } \\
\text { radionuclides include technetium-99, } \\
\text { iodine-129, and uranium }\end{array}$ & $\begin{array}{l}\text { Central Plateau and River } \\
\text { Corridor }\end{array}$ & $\begin{array}{l}\text { COS (lead) and SAC; } \\
\text { Tank Farm Vadose } \\
\text { Zone, } \\
\text { BBI/HTWOS/HDW; } \\
\text { BNI G2 }\end{array}$ & \begin{tabular}{|l|} 
Project COS and \\
SAC, 200 Area \\
Remedial Action \\
Project, Tank Farm \\
Vadose Zone Project
\end{tabular} & $10 / 03$ & $4 / 06$ \\
\hline
\end{tabular}


Table 4.1 (Contd)

\begin{tabular}{|c|c|c|c|c|c|c|c|c|}
\hline Id No. & S\&T Activity & \begin{tabular}{|l|} 
Descriptive \\
Title \\
\end{tabular} & Brief Scope and Outcome & Hanford Site PBS & Interacts With & Product To & $\begin{array}{l}\text { Desired } \\
\text { Start } \\
\text { Date of } \\
\text { S\&T } \\
\text { Activity } \\
\end{array}$ & $\begin{array}{l}\text { Product } \\
\text { Delivery } \\
\text { Date }\end{array}$ \\
\hline Inv-8 & \begin{tabular}{|l|} 
Field \\
Confirmation of \\
Inventory \\
Composition
\end{tabular} & $\begin{array}{l}\text { Identification of } \\
\text { Needed Field } \\
\text { Observations } \\
\text { from } \\
\text { Characterization } \\
\text { Efforts }\end{array}$ & $\begin{array}{l}\text { The scope of this activity is to identify } \\
\text { field observations that will discriminate } \\
\text { among alternate hypotheses as to the } \\
\text { waste-stream discharge compositions at } \\
\text { each of the specific classes of Hanford } \\
\text { waste sites identified by the } 200 \text { Area } \\
\text { Characterization Project and the remaining } \\
\text { tank farm characterization efforts } \\
\text { (T-TX-TY, A-AX, C, and U. }\end{array}$ & Central Plateau & $\begin{array}{l}200 \text { Area Remedial } \\
\text { Action, Tank Farm } \\
\text { Vadose Zone }\end{array}$ & $\begin{array}{l}\text { COS and SAC; } 200 \\
\text { Area Remedial } \\
\text { Action Project, } \\
\text { Tank Farm Vadose } \\
\text { Zone Project }\end{array}$ & $10 / 02$ & $3 / 08$ \\
\hline
\end{tabular}


Table 4.2. Schedule and Products for Subsurface Transport Technical Element

\begin{tabular}{|c|c|c|c|c|c|c|c|c|}
\hline Id No. & S\&T Activity & $\begin{array}{l}\text { Descriptive } \\
\text { Title }\end{array}$ & Brief Scope and Outcome & Hanford Site PBS & Interacts With & Product To & $\begin{array}{l}\text { Desired } \\
\text { Start } \\
\text { Date of } \\
\text { S\&T } \\
\text { Activity }\end{array}$ & $\begin{array}{l}\text { Product } \\
\text { Delivery } \\
\text { Date }\end{array}$ \\
\hline ST-1 & \begin{tabular}{|l|} 
Vadose-Zone \\
Transport Field \\
Studies
\end{tabular} & \begin{tabular}{|l} 
Effective \\
Parameters for \\
Unsaturated \\
Flow in \\
Heterogeneous \\
Sediments
\end{tabular} & $\begin{array}{l}\text { The scope of this activity is to evaluate } \\
\text { results from FY02 controlled, multi-scale } \\
\text { vadose-zone transport field experiment } \\
\text { with water and dilute tracers in } \\
\text { heterogeneous sediments to develop } \\
\text { improved conceptual models and } \\
\text { upscaling methodologies. The study will } \\
\text { examine effective parameters, derived } \\
\text { inverse methods, and upscaling } \\
\text { methodologies that can be used in fate- } \\
\text { and-transport models. }\end{array}$ & Central Plateau & $\begin{array}{l}\text { COS and SAC, Tank } \\
\text { Farm Vadose Zone } \\
\text { Project }\end{array}$ & $\begin{array}{l}\text { SAC, Tank Farm } \\
\text { Vadose Zone } \\
\text { Project (T-TX-TY } \\
\text { FIR 4/04) }\end{array}$ & $10 / 02$ & $9 / 03$ \\
\hline ST-2 & \begin{tabular}{|l} 
Vadose-Zone \\
Transport Field \\
Studies
\end{tabular} & \begin{tabular}{|l|} 
Transport and \\
Fate of Uranium \\
in Physically \\
and Chemically \\
Heterogeneous \\
Sediments \\
\end{tabular} & \begin{tabular}{|l|} 
The scope of this activity is to perform a \\
vadose-zone transport field experiment \\
with uranium (VI) to improve description \\
and prediction of reactive solute transport. \\
Develop effective or macroscopic \\
transport coefficients for a reactive solute, \\
uranium (VI), sorbing under local \\
equilibrium conditions in heterogeneous \\
sediments where retardation, velocity, and \\
micro-dispersion coefficients vary in space \\
and time. Perform reactive transport \\
modeling of field experiment.
\end{tabular} & \begin{tabular}{|l} 
Central Plateau \\
\end{tabular} & $\begin{array}{l}\text { COS and SAC, Tank } \\
\text { Farm Vadose Zone } \\
\text { Project, } 200 \text { Area } \\
\text { Remedial Action } \\
\text { Project }\end{array}$ & $\begin{array}{l}\text { SAC, Tank Farm } \\
\text { Vadose Zone } \\
\text { Project (T-TX-TY } \\
\text { FIR 4/04) }\end{array}$ & $10 / 02$ & $9 / 04$ \\
\hline ST-3 & \begin{tabular}{|l} 
Vadose-Zone \\
Transport Field \\
Studies
\end{tabular} & \begin{tabular}{|l|} 
Advanced \\
Characterization \\
and Vadose- \\
Zone \\
Monitoring \\
Systems \\
\end{tabular} & $\begin{array}{l}\text { The scope of this activity is to develop } \\
\text { methods for characterizing the spatial } \\
\text { distribution of hydraulic properties. The } \\
\text { approach will be to use data synthesis } \\
\text { from geophysical methods to identify } \\
\text { hydraulic properties and their spatial } \\
\text { structure. The goal is to optimize the } \\
\text { detection of subsurface moisture and } \\
\text { contaminant plumes. }\end{array}$ & Central Plateau & $\begin{array}{l}\text { Leak Detection, } \\
\text { Mitigation, and } \\
\text { Monitoring (LDMM) } \\
\text { Project, 200 Area } \\
\text { Remedial Action } \\
\text { Project }\end{array}$ & $\begin{array}{l}\text { Tank Farm Vadose } \\
\text { Zone Project } \\
\text { (T-TX-TY FIR } \\
\text { 4/04), 200 Area } \\
\text { Remedial Action } \\
\text { Project (RCRA } \\
\text { Modified C Barrier } \\
\text { Placement 9/06) }\end{array}$ & $10 / 02$ & $9 / 05$ \\
\hline
\end{tabular}


Table 4.2 (Contd)

\begin{tabular}{|c|c|c|c|c|c|c|c|c|}
\hline Id No. & S\&T Activity & $\begin{array}{l}\text { Descriptive } \\
\text { Title }\end{array}$ & Brief Scope and Outcome & Hanford Site PBS & Interacts With & Product To & \begin{tabular}{|l} 
Desired \\
Start \\
Date of \\
S\&T \\
Activity
\end{tabular} & $\begin{array}{l}\text { Product } \\
\text { Delivery } \\
\text { Date }\end{array}$ \\
\hline ST-4 & \begin{tabular}{|l|} 
Vadose-Zone \\
Transport Field \\
Studies
\end{tabular} & $\begin{array}{l}\text { Recharge } \\
\text { Assessments }\end{array}$ & $\begin{array}{l}\text { The scope of this activity is to provide } \\
\text { improved estimates of recharge for } \\
\text { Hanford using data from vadose-zone } \\
\text { monitoring and field experiments. } \\
\text { Advanced characterization and monitoring } \\
\text { systems will be developed and deployed at } \\
\text { Hanford waste sites, including tank farms, } \\
\text { past liquid disposal sites, and burial } \\
\text { grounds. Short and long-term estimates of } \\
\text { recharge rates for Hanford waste sites } \\
\text { under different surface conditions } \\
\text { (vegetation) will be made. The long-term } \\
\text { recharge record for the Hanford Site will } \\
\text { be maintained. }\end{array}$ & \begin{tabular}{|l|} 
Central Plateau \\
\\
\end{tabular} & \begin{tabular}{|l|} 
Tank Farm Vadose \\
Zone Project, 200 \\
Area Remedial Action \\
Project, ILAW \\
\\
\end{tabular} & $\begin{array}{l}\text { COS and SAC, } \\
\text { Immobilized Low } \\
\text { Activity Waste } \\
\text { Disposal Project, } \\
\text { Tank Farm Vadose } \\
\text { Zone Project } \\
\text { (T-TX-TY FIR } \\
\text { 4/04), Groundwater } \\
\text { Project, 200 Area } \\
\text { Remedial Action } \\
\text { Project }\end{array}$ & $10 / 03$ & $9 / 04$ \\
\hline ST-5 & $\begin{array}{l}\text { Release Process } \\
\text { Models }\end{array}$ & $\begin{array}{l}\text { Release Model } \\
\text { Development }\end{array}$ & $\begin{array}{l}\text { The scope of this activity is to evaluate and } \\
\text { enhance existing source-term release } \\
\text { models or develop new models. Release } \\
\text { models requiring technical support include } \\
\text { the soil-debris model, the cement model, } \\
\text { the reactor block (graphite) model, and the } \\
\text { salt cake model. Develop the next } \\
\text { generation release models, e.g., release } \\
\text { models for SST contents, including salt } \\
\text { cake, sludge, and hard heal. The release } \\
\text { model specifically needs to target } \\
\text { technetium-99 and other key contaminant } \\
\text { releases from HLW tanks. }\end{array}$ & Central Plateau & $\begin{array}{l}\text { COS and SAC, Tank } \\
\text { Farm Vadose Zone } \\
\text { Project (lead for } \\
\text { technetium-99 } \\
\text { releases from high- } \\
\text { level waste [HLW] } \\
\text { tanks), ILAW for } \\
\text { glass, grout, and other } \\
\text { waste forms }\end{array}$ & \begin{tabular}{|l} 
COS and SAC \\
\end{tabular} & $10 / 02$ & 6/04 \\
\hline
\end{tabular}


Table 4.2 (Contd)

\begin{tabular}{|c|c|c|c|c|c|c|c|c|}
\hline Id No. & S\&T Activity & $\begin{array}{l}\text { Descriptive } \\
\text { Title }\end{array}$ & Brief Scope and Outcome & Hanford Site PBS & Interacts With & Product To & $\begin{array}{l}\text { Desired } \\
\text { Start } \\
\text { Date of } \\
\text { S\&T } \\
\text { Activity }\end{array}$ & $\begin{array}{l}\text { Product } \\
\text { Delivery } \\
\text { Date }\end{array}$ \\
\hline ST-6 & $\begin{array}{l}\text { Linkage of } \\
\text { Stochastic } \\
\text { Models of } \\
\text { Disparate Scales }\end{array}$ & \begin{tabular}{|l} 
Development \\
of a Joint- \\
Multi-scale \\
Stochastic \\
Simulation
\end{tabular} & $\begin{array}{l}\text { The scope of this activity is to develop a } \\
\text { method for adopting results from more } \\
\text { detailed and sophisticated site-specific } \\
\text { models of inventory, waste-form release, } \\
\text { and ultimately contamination release to the } \\
\text { water table (e.g., nonisothermal, reactive } \\
\text { geochemistry, two- and three-dimensional } \\
\text { flow and transport) as input to a stochastic } \\
\text { site-wide model (e.g., the SAC). Address } \\
\text { the issues of scaleup where appropriate, } \\
\text { and of joint stochastic analyses using site- } \\
\text { specific and site-wide scale models. }\end{array}$ & \begin{tabular}{|l} 
Central Plateau \\
\end{tabular} & $\begin{array}{l}\text { COS and SAC, Tank } \\
\text { Farm Vadose Zone } \\
\text { Project, } 200 \text { Area } \\
\text { Remedial Action } \\
\text { Project }\end{array}$ & COS and SAC & $10 / 03$ & $6 / 04$ \\
\hline ST-7 & Geochemistry & $\begin{array}{l}\text { Uranium } \\
\text { Mobility }\end{array}$ & $\begin{array}{l}\text { The scope of this activity is to evaluate in- } \\
\text { ground uranium (VI) speciation and } \\
\text { develop mobility models for tank waste } \\
\text { sites, } 200 \text { Area soil sites and } 300 \text { Area } \\
\text { uranium (VI) plume ( } 300-\mathrm{FF}-5 \text { ). } \\
\text { Incorporate new knowledge of uranium } \\
\text { (VI) speciation and geochemistry into } \\
\text { reactive transport models to evaluate } \mathrm{K}_{\mathrm{d}} \mathrm{S} \\
\text { used in SAC and other site assessments. } \\
\text { Evaluate monitored natural attenuation for } \\
\text { 300-Area plume. }\end{array}$ & Central Plateau & $\begin{array}{l}\text { Tank Farm Vadose } \\
\text { Zone Project, } 200 \\
\text { Area Remedial Action } \\
\text { Project, Groundwater } \\
\text { Project, COS and SAC }\end{array}$ & $\begin{array}{l}\text { Tank Farm Vadose } \\
\text { Zone Project } \\
\text { (T-TY-TY FIR } \\
\text { 4/04; A-AX/C/U } \\
\text { 4/06), 200 Area } \\
\text { Remedial Action } \\
\text { Project (PW-2 RI } \\
\text { Report 6/04), } \\
\text { Groundwater } \\
\text { Project } \\
\text { (Comprehensive } \\
\text { Environmental } \\
\text { Response, } \\
\text { Compensation, and } \\
\text { Liability Act } \\
\text { [CERCLA] 5-year } \\
\text { review, 9/05), COS }\end{array}$ & $10 / 02$ & $4 / 06$ \\
\hline
\end{tabular}


Table 4.2 (Contd)

\begin{tabular}{|c|c|c|c|c|c|c|c|c|}
\hline Id No. & S\&T Activity & \begin{tabular}{|l} 
Descriptive \\
Title
\end{tabular} & Brief Scope and Outcome & Hanford Site PBS & Interacts With & Product To & $\begin{array}{l}\text { Desired } \\
\text { Start } \\
\text { Date of } \\
\text { S\&T } \\
\text { Activity }\end{array}$ & $\begin{array}{l}\text { Product } \\
\text { Delivery } \\
\text { Date }\end{array}$ \\
\hline ST-8 & Geochemistry & $\begin{array}{l}\text { Strontium-90 } \\
\text { Adsorption } \\
\text { Model }\end{array}$ & \begin{tabular}{|l|} 
Collaborate with EMSP to develop a \\
geochemical reaction model for \\
strontium-90 that can be applied in tank \\
farms, 200 Area Soil Sites, and $100-\mathrm{N}$ \\
strontium-90 plume to evaluate Monitored \\
Natural Attenuation. Incorporate new \\
knowledge of strontium-90 complexation \\
into reactive transport models to \\
investigate strontium-90 mobility in \\
Hanford sediments
\end{tabular} & Central Plateau, River Corridor & \begin{tabular}{|l|} 
Tank Farm Vadose \\
Zone Project, 200 \\
Area Remedial Action \\
Project, Groundwater \\
Project, EMSP, COS \\
and SAC \\
\end{tabular} & \begin{tabular}{|l|} 
Tank Farm Vadose \\
Zone Project \\
(B-BX-BY FIR \\
8/02), 200 Area \\
Remedial Action \\
Project and \\
Groundwater \\
Project (CERCLA \\
5-year review 9/05), \\
COS
\end{tabular} & $10 / 02$ & $9 / 04$ \\
\hline ST-9 & Geochemistry & $\begin{array}{l}\text { Iodine-129 } \\
\text { mobility }\end{array}$ & \begin{tabular}{|l|} 
Perform laboratory experiments on \\
different Hanford sediment types to \\
quantify an adsorption model for different \\
iodine-129 species leading to improved \\
groundwater mobility calculations. \\
Incorporate experimental results into \\
reactive transport model to investigate \\
iodine-129 mobility
\end{tabular} & Central Plateau & COS and SAC, ILAW & $\begin{array}{l}\text { COS and SAC, } \\
\text { Tank Farm Vadose } \\
\text { Zone Project }\end{array}$ & $10 / 04$ & $9 / 05$ \\
\hline ST-10 & Geochemistry & $\begin{array}{l}\text { Speciation and } \\
\text { mobility of } \\
\text { transuranics }\end{array}$ & \begin{tabular}{|l|} 
Perform speciation, microscopy, and \\
laboratory manipulating experiments on \\
plutonium and americium containing \\
sediments from 200 Area soil sites to \\
develop improved conceptual and \\
migration models. Incorporate \\
experimental results into reactive flow- \\
and-transport models.
\end{tabular} & Central Plateau & $\begin{array}{l}200 \text { Area Remedial } \\
\text { Action Project }\end{array}$ & $\begin{array}{l}200 \text { Area Remedial } \\
\text { Action Project } \\
(\mathrm{TW}-2 \text { in } 9 / 02, \\
\mathrm{CW}-5 \text { in } 6 / 03, \mathrm{PW}- \\
1 \text { in } 6 / 05)\end{array}$ & $10 / 05$ & $9 / 06$ \\
\hline ST-11 & Geochemistry & \begin{tabular}{|l} 
Effects of \\
organic \\
complexants on \\
mobility of key \\
contaminants
\end{tabular} & \begin{tabular}{|l} 
Laboratory experiments with contaminated \\
tank-farm materials receiving high \\
complexant waste (e.g., B-110, T-106) and \\
"pristine simulants" to determine \\
magnitude of facilitated transport.
\end{tabular} & Central Plateau & \begin{tabular}{|l|} 
Tank Farm Vadose \\
Zone Project, EMSP
\end{tabular} & \begin{tabular}{|l|} 
Tank Farm Vadose \\
Zone Project \\
(T-TX-TY FIR in \\
$4 / 04$, A-AX, C, and \\
U in $10 / 05$ )
\end{tabular} & $10 / 02$ & $10 / 05$ \\
\hline
\end{tabular}


Table 4.2 (Contd)

\begin{tabular}{|c|c|c|c|c|c|c|c|c|}
\hline Id No. & S\&T Activity & $\begin{array}{l}\text { Descriptive } \\
\text { Title }\end{array}$ & Brief Scope and Outcome & Hanford Site PBS & Interacts With & Product To & \begin{tabular}{|l} 
Desired \\
Start \\
Date of \\
S\&T \\
Activity
\end{tabular} & $\begin{array}{l}\text { Product } \\
\text { Delivery } \\
\text { Date }\end{array}$ \\
\hline ST-12 & Geochemistry & $\begin{array}{l}\text { Chromium } \\
\text { mobility }\end{array}$ & $\begin{array}{l}\text { Perform laboratory experiments on } \\
\text { different Hanford sediment types to } \\
\text { quantify an adsorption model for different } \\
\text { chromium species leading to improved } \\
\text { groundwater mobility calculations. } \\
\text { Incorporate experimental results into } \\
\text { reactive transport model to investigate } \\
\text { chromium mobility }\end{array}$ & Central Plateau, River Corridor & $\begin{array}{l}\text { Integration Project } \\
\text { COS and SAC }\end{array}$ & $\begin{array}{l}\text { COS and SAC, } \\
\text { Tank Farm Vadose } \\
\text { Zone Project, } 100 \\
\text { Area Remedial } \\
\text { Action Project }\end{array}$ & $10 / 05$ & $9 / 05$ \\
\hline ST-13 & Geochemistry & \begin{tabular}{|l|} 
Carbon \\
tetrachloride \\
transport and \\
mobility and \\
degradation
\end{tabular} & $\begin{array}{l}\text { Perform laboratory experiments on } \\
\text { migration of liquid and dissolved carbon } \\
\text { tetrachloride and develop improved, multi- } \\
\text { phase reactive transport models. } \\
\text { Incorporate new knowledge of carbon } \\
\text { tetrachloride fluid properties, phase } \\
\text { behavior, residual formation, and } \\
\text { interaction with calcite-bearing sediments } \\
\text { into multiphase reactive transport models } \\
\text { to investigate carbon tetrachloride mobility } \\
\text { and degradation in Hanford sediments. }\end{array}$ & Central Plateau & $\begin{array}{l}200 \text { Area Remedial } \\
\text { Action Project, COS } \\
\text { and SAC }\end{array}$ & $\begin{array}{l}200 \text { Area Remedial } \\
\text { Action Project, } \\
\text { Groundwater } \\
\text { Project }\end{array}$ & $10 / 03$ & 9/04 \\
\hline ST-14 & Geochemistry & $\begin{array}{l}\text { Quantitative } \\
\text { Conceptual } \\
\text { Models- } \\
\text { WMA B-BX- } \\
\text { BY }\end{array}$ & $\begin{array}{l}\text { Perform speciation and microscopy } \\
\text { measurements and laboratory manipulation } \\
\text { experiments on contaminated WMA } \\
\text { sediments to define the geochemical } \\
\text { behavior of U(VI) (BX-102) and } \\
\text { strontium-90 (B-110) for input to FIR. } \\
\text { Incorporate experimental results into } \\
\text { reactive transport models to evaluate the } \\
\text { mobility of key contaminants, } \\
\text { strontium-90, uranium-238. }\end{array}$ & Central Plateau & $\begin{array}{l}\text { Tank Farm Vadose } \\
\text { Zone Project (Lead) }\end{array}$ & $\begin{array}{l}\text { Tank Farm Vadose } \\
\text { Zone Project } \\
\text { (B-BX-BY FIR in } \\
\text { 8/02), COS and } \\
\text { SAC }\end{array}$ & $10 / 01$ & $9 / 02$ \\
\hline
\end{tabular}


Table 4.2 (Contd)

\begin{tabular}{|c|c|c|c|c|c|c|c|c|}
\hline Id No. & S\&T Activity & \begin{tabular}{|l} 
Descriptive \\
Title
\end{tabular} & Brief Scope and Outcome & Hanford Site PBS & Interacts With & Product To & $\begin{array}{l}\text { Desired } \\
\text { Start } \\
\text { Date of } \\
\text { S\&T } \\
\text { Activity }\end{array}$ & $\begin{array}{l}\text { Product } \\
\text { Delivery } \\
\text { Date }\end{array}$ \\
\hline ST-15 & Geochemistry & $\begin{array}{l}\text { Quantitative } \\
\text { Conceptual } \\
\text { Models- } \\
\text { WMA T-TX- } \\
\text { TY }\end{array}$ & $\begin{array}{l}\text { Perform speciation and microscopy } \\
\text { measurements and laboratory manipulation } \\
\text { experiments on contaminated WMA } \\
\text { sediments to define the geochemical } \\
\text { behavior of metal wastes (TX-105) and } \\
\text { B-plant wastes (TX-107; T-106). Input } \\
\text { provided to FIR. Incorporate experimental } \\
\text { results into reactive transport models to } \\
\text { evaluate the mobility of key contaminants, } \\
\text { cesium-137, strontium-90, uranium-238, } \\
\text { technetium-99, and chromium. }\end{array}$ & Central Plateau & $\begin{array}{l}\text { Tank Farm Vadose } \\
\text { Zone Project (Lead) }\end{array}$ & $\begin{array}{l}\text { Tank Farm Vadose } \\
\text { Zone Project } \\
\text { (T-TX-TY FIR), } \\
\text { COS and SAC }\end{array}$ & $5 / 02$ & $4 / 04$ \\
\hline ST-16 & Geochemistry & $\begin{array}{l}\text { Quantitative } \\
\text { Conceptual } \\
\text { Models- } \\
\text { WMA } \\
\text { A/AX/C/U } \\
\end{array}$ & $\begin{array}{l}\text { Perform speciation and microscopy } \\
\text { measurements and laboratory manipulation } \\
\text { experiments on contaminated WMA } \\
\text { sediments to resolve key issues of } \\
\text { contaminant/waste migration. }\end{array}$ & Central Plateau & \begin{tabular}{|l} 
Tank Farm Vadose \\
Zone Project (Lead)
\end{tabular} & $\begin{array}{l}\text { Tank Farm Vadose } \\
\text { Zone Project } \\
\text { (A/AX/U FIR } \\
\text { 4/06), COS and } \\
\text { SAC }\end{array}$ & $10 / 04$ & $4 / 06$ \\
\hline ST-17 & \begin{tabular}{|l} 
Transport \\
Modeling
\end{tabular} & \begin{tabular}{|l|} 
Reactive \\
transport \\
models to \\
support \\
remediation \\
design
\end{tabular} & $\begin{array}{l}\text { The scope of this activity is to develop and } \\
\text { implement reactive transport models for } \\
\text { design of remediation treatment systems. } \\
\text { The scope includes codes that support } \\
\text { evaluation of reaction kinetics and reaction } \\
\text { zones, incorporation of heterogeneities, } \\
\text { and reaction/mobility of key contaminants } \\
\text { (strontium-90, technetium-99, uranium, } \\
\text { chromium, and carbon tetrachloride). } \\
\text { Includes improved models, visualization } \\
\text { methods, and computational capabilities }\end{array}$ & \begin{tabular}{|l|} 
Central Plateau, River Corridor \\
\end{tabular} & \begin{tabular}{|l|}
200 Area Remedial \\
Action Project, \\
Groundwater Project, \\
Tank Farm Vadose \\
Zone Project
\end{tabular} & $\begin{array}{l}200 \text { Area Remedial } \\
\text { Action Project, } \\
\text { Groundwater } \\
\text { Project (CERCLA } \\
\text { 5-year review) }\end{array}$ & $10 / 03$ & $9 / 05$ \\
\hline ST-18 & $\begin{array}{l}\text { Groundwater } \\
\text { Transport }\end{array}$ & $\begin{array}{l}\text { Groundwater } \\
\text { Flow and } \\
\text { Transport } \\
\text { Evaluations }\end{array}$ & $\begin{array}{l}\text { The scope of this activity is to investigate } \\
\text { and characterize impacts of multiple scales } \\
\text { of heterogeneity on groundwater flow and } \\
\text { transport }\end{array}$ & Central Plateau & $\begin{array}{l}\text { Groundwater Project } \\
(\text { Lead), COS and SAC }\end{array}$ & $\begin{array}{l}\text { Groundwater } \\
\text { Project, COS and } \\
\text { SAC }\end{array}$ & $10 / 03$ & $9 / 04$ \\
\hline
\end{tabular}


Table 4.2 (Contd)

\begin{tabular}{|c|c|c|c|c|c|c|c|c|}
\hline Id No. & S\&T Activity & \begin{tabular}{|l} 
Descriptive \\
Title \\
\end{tabular} & Brief Scope and Outcome & Hanford Site PBS & Interacts With & Product To & \begin{tabular}{|l} 
Desired \\
Start \\
Date of \\
S\&T \\
Activity \\
\end{tabular} & \begin{tabular}{|l} 
Product \\
Delivery \\
Date \\
\end{tabular} \\
\hline ST-19 & $\begin{array}{l}\text { Groundwater } \\
\text { Transport }\end{array}$ & $\begin{array}{l}\text { Groundwater } \\
\text { and Vadose } \\
\text { Zone Interface } \\
\text { Study }\end{array}$ & \begin{tabular}{|l|} 
The scope of this activity is to perform \\
spatial and temporal interpretation of \\
historical groundwater data to evaluate \\
three-dimensional contaminant plumes at \\
the vadose zone/groundwater interface. \\
Additional depth-discrete data will be \\
collected from existing and new wells near \\
HLW tanks that have leaked and impacted \\
groundwater. The outcome will be a \\
documented evaluation of three- \\
dimensional plume development beneath \\
leaked HLW tanks and key soil waste sites \\
to support numerical transport modeling. \\
\end{tabular} & \begin{tabular}{|l} 
Central Plateau \\
\\
\end{tabular} & $\begin{array}{l}\text { Groundwater Project } \\
\text { (Lead), COS and } \\
\text { SAC, Tank Farm } \\
\text { Vadose Zone Project }\end{array}$ & $\begin{array}{l}\text { Groundwater } \\
\text { Project (Lead), } \\
\text { COS and SAC, } \\
\text { Tank Farm Vadose } \\
\text { Zone Project } \\
\text { (T-TX-TY 4/04, A- } \\
\text { AX/C/U 4/06) }\end{array}$ & $10 / 02$ & $4 / 06$ \\
\hline ST-20 & $\begin{array}{l}\text { Groundwater } \\
\text { Transport }\end{array}$ & $\begin{array}{l}\text { Groundwater } \\
\text { Dispersivity } \\
\text { Estimates }\end{array}$ & \begin{tabular}{|l|} 
The scope of this activity is to develop \\
estimates of dispersivity for key \\
groundwater contaminants. Historical \\
groundwater data will be reviewed and \\
interpreted with the objective of \\
determining appropriate dispersivity \\
estimates as a function of distance traveled \\
and hydrogeologic unit. These dispersivity \\
estimates will be used in site-wide and \\
site-specific groundwater transport models.
\end{tabular} & Central Plateau & $\begin{array}{l}\text { Groundwater Project } \\
\text { (Lead), COS and } \\
\text { SAC, Tank Farm } \\
\text { Vadose Zone Project }\end{array}$ & $\begin{array}{l}\text { Groundwater } \\
\text { Project (Lead), } \\
\text { COS and SAC, } \\
\text { Tank Farm Vadose } \\
\text { Zone Project } \\
\text { (T-TX-TY 4/04, A- } \\
\text { AX/C/U 4/06) }\end{array}$ & $10 / 03$ & $9 / 04$ \\
\hline
\end{tabular}


Table 4.2 (Contd)

\begin{tabular}{|c|c|c|c|c|c|c|c|c|}
\hline Id No. & S\&T Activity & $\begin{array}{l}\text { Descriptive } \\
\text { Title }\end{array}$ & Brief Scope and Outcome & Hanford Site PBS & Interacts With & Product To & \begin{tabular}{|l} 
Desired \\
Start \\
Date of \\
S\&T \\
Activity \\
\end{tabular} & $\begin{array}{l}\text { Product } \\
\text { Delivery } \\
\text { Date } \\
\end{array}$ \\
\hline ST-21 & \begin{tabular}{|l|} 
Groundwater- \\
River Interface
\end{tabular} & $\begin{array}{l}\text { Remote } \\
\text { Sensing to } \\
\text { Define Extent } \\
\text { of Riverbed } \\
\text { Interface with } \\
\text { Aquifer }\end{array}$ & \begin{tabular}{|l|} 
Define locations of where contaminated \\
groundwater from the Hanford Site \\
discharges to the riverbed. Evaluate \\
remote sensing data to identify locations of \\
groundwater discharge. The result will be \\
data and information to enhance \\
environmental monitoring strategies, \\
performance assessment of remedial \\
actions, and assessment of risk to \\
ecosystem.
\end{tabular} & \begin{tabular}{|l} 
River Corridor \\
\end{tabular} & \begin{tabular}{|l|} 
River Monitoring \\
Project, Groundwater \\
Project, COS and SAC
\end{tabular} & $\begin{array}{l}\text { River Corridor } \\
\text { Project (CERCLA } \\
\text { 5-year review) }\end{array}$ & $10 / 03$ & $9 / 04$ \\
\hline ST-22 & $\begin{array}{l}\text { Groundwater- } \\
\text { River Interface }\end{array}$ & \begin{tabular}{|l|} 
Test Facility for \\
three- \\
dimensional \\
Data Zone of \\
Interaction \\
\end{tabular} & $\begin{array}{l}\text { Install three-dimensional array of access } \\
\text { points (boreholes or cone penetrometer) } \\
\text { with pressure and chemistry sensors. } \\
\text { Obtain data to verify water-movement } \\
\text { simulation model and contaminant-dilution } \\
\text { estimates. Provides conceptual basis for } \\
\text { post-remedial action monitoring strategy } \\
\text { for River Corridor (by 2012). }\end{array}$ & River Corridor & \begin{tabular}{|l|} 
River Monitoring \\
Project, Groundwater \\
Monitoring Project, \\
Integration Project \\
COS and SAC
\end{tabular} & \begin{tabular}{|l|} 
Groundwater \\
Monitoring Project, \\
River Monitoring \\
Project, SAC \\
LOW PRIORITY - \\
FUTURE SCOPE \\
\end{tabular} & 2010 & 2012 \\
\hline
\end{tabular}


Table 4.3. Schedule and Products for Columbia River and Risk Technical Element

\begin{tabular}{|c|c|c|c|c|c|c|c|c|}
\hline Id No. & S\&T Activity & Descriptive Title & Brief Scope and Outcome & Hanford Site PBS & Interacts With & Product To & \begin{tabular}{|l|} 
Desired \\
Start \\
Date of \\
S\&T \\
Activity
\end{tabular} & $\begin{array}{l}\text { Product } \\
\text { Delivery } \\
\text { Date }\end{array}$ \\
\hline CRR-1 & Columbia River & \begin{tabular}{|l|} 
Enhance \\
Ecological \\
Characterization \\
300-Area River \\
Corridor
\end{tabular} & $\begin{array}{l}\text { Core projects are planning ecological and } \\
\text { contaminant characterization to obtain } \\
\text { additional information on Hanford- } \\
\text { derived contaminants in the Columbia } \\
\text { River along the } 300 \text { Area river corridor. } \\
\text { This activity will investigate ecological } \\
\text { and contaminant fate and transport in the } \\
\text { Columbia River to support site-wide and } \\
\text { site-specific risk assessments, including } \\
\text { physical, chemical, and biological } \\
\text { processes that reduce contaminant } \\
\text { concentrations, mass, mobility and/or } \\
\text { toxicity at the groundwater/river } \\
\text { interface. }\end{array}$ & River Corridor & $\begin{array}{l}\text { SAC, River } \\
\text { Monitoring Project, } \\
\text { Ecological Risk } \\
\text { Assessment S\&T } \\
\text { Activity, COS, River } \\
\text { Corridor Project }\end{array}$ & $\begin{array}{l}\text { SAC, River } \\
\text { Corridor Project } \\
\text { (Milestone M-016- } \\
01-06)\end{array}$ & $10 / 02$ & $9 / 03$ \\
\hline CRR-2 & Columbia River & \begin{tabular}{|l|} 
Enhance \\
Ecological \\
Characterization \\
100-Area River \\
Corridor
\end{tabular} & $\begin{array}{l}\text { Core projects are planning ecological and } \\
\text { contaminant characterization to obtain } \\
\text { additional information on Hanford- } \\
\text { derived contaminants in the Columbia } \\
\text { River along the } 100 \text { Area river corridor. } \\
\text { This activity will investigate ecological } \\
\text { and contaminant fate and transport in the } \\
\text { Columbia River to support site-wide and } \\
\text { site-specific risk assessments, including } \\
\text { physical, chemical, and biological } \\
\text { processes that reduce contaminant } \\
\text { concentrations, mass, mobility, and/or } \\
\text { toxicity at the groundwater/river } \\
\text { interface. }\end{array}$ & River Corridor & \begin{tabular}{|l|} 
River Monitoring \\
Project, River \\
Corridor Project, \\
Public Safety and \\
Resource Protection \\
Project, COS and SAC
\end{tabular} & \begin{tabular}{|l|} 
River Corridor \\
Project (Milestone \\
M-016-01-05)
\end{tabular} & $6 / 03$ & $9 / 04$ \\
\hline
\end{tabular}


Table 4.3 (Contd)

\begin{tabular}{|c|c|c|c|c|c|c|c|c|}
\hline Id No. & S\&T Activity & Descriptive Title & Brief Scope and Outcome & Hanford Site PBS & Interacts With & Product To & $\begin{array}{l}\text { Desired } \\
\text { Start } \\
\text { Date of } \\
\text { S\&T } \\
\text { Activity }\end{array}$ & $\begin{array}{l}\text { Product } \\
\text { Delivery } \\
\text { Date }\end{array}$ \\
\hline CRR-3 & Columbia River & \begin{tabular}{|l} 
Contaminant \\
Transport \\
Models for River
\end{tabular} & $\begin{array}{l}\text { The scope of this activity is to develop } \\
\text { and apply a contaminant-transport model } \\
\text { for the Hanford Reach of the Columbia } \\
\text { River, including hydrodynamic, } \\
\text { sediment, and biological transport } \\
\text { components. The scope of this activity is } \\
\text { to determine biological transfer factors } \\
\text { for contaminant/species combinations of } \\
\text { interest. The outcome will be a validated } \\
\text { and documented numerical contaminant- } \\
\text { transport model, including sediment and } \\
\text { biological transport, for the Hanford } \\
\text { Reach of the Columbia River. }\end{array}$ & River Corridor & $\begin{array}{l}\text { SAC (Lead) and } \\
\text { Public Safety and } \\
\text { Resource Protection } \\
\text { Project }\end{array}$ & $\begin{array}{l}\text { COS and SAC, } \\
\text { River Monitoring } \\
\text { Project }\end{array}$ & $10 / 02$ & $9 / 04$ \\
\hline CRR-4 & Columbia River & $\begin{array}{l}\text { Entrainment of } \\
\text { River Water in } \\
\text { Bed Sediment }\end{array}$ & $\begin{array}{l}\text { Investigate the geomorphic controls on } \\
\text { entrainment of river water in bed } \\
\text { sediment; conduct field experiments to } \\
\text { determine impact on pore water quality } \\
\text { relative to influx of groundwater in key } \\
\text { contaminated areas such as } 100-\mathrm{N} \text { and } \\
\text { chromium contaminated areas. }\end{array}$ & River Corridor & $\begin{array}{l}\text { COS and SAC, River } \\
\text { Monitoring Project, } \\
\text { Groundwater Project }\end{array}$ & $\begin{array}{l}\text { River Corridor } \\
\text { Project, } \\
\text { Groundwater } \\
\text { Project (CERCLA } \\
\text { 5-year review) }\end{array}$ & $10 / 04$ & $9 / 05$ \\
\hline CRR-5 & Columbia River & $\begin{array}{l}\text { In situ } \\
\text { technologies for } \\
\text { river monitoring }\end{array}$ & $\begin{array}{l}\text { Cost-effective } \text { in } \text { situ } \text { monitoring } \\
\text { instruments are needed for measuring } \\
\text { water-quality parameters in the Columbia } \\
\text { River. Improvements are needed for } \\
\text { faster turn-around times, lower detection } \\
\text { levels, lower costs, reduction in } \\
\text { interferences, and reduction in sample } \\
\text { size. Key contaminants of concern } \\
\text { include strontium-90, chromium, and } \\
\text { uranium. }\end{array}$ & River Corridor & $\begin{array}{l}\text { River Monitoring } \\
\text { Project, Integration } \\
\text { Project COS and SAC, } \\
\text { EMSP }\end{array}$ & $\begin{array}{l}\text { River Corridor } \\
\text { Project (CERCLA } \\
\text { 5-Year Review) }\end{array}$ & $10 / 03$ & $9 / 05$ \\
\hline
\end{tabular}


Table 4.3 (Contd)

\begin{tabular}{|c|c|c|c|c|c|c|c|c|}
\hline Id No. & S\&T Activity & Descriptive Title & Brief Scope and Outcome & Hanford Site PBS & Interacts With & Product To & \begin{tabular}{|l|} 
Desired \\
Start \\
Date of \\
S\&T \\
Activity \\
\end{tabular} & $\begin{array}{l}\text { Product } \\
\text { Delivery } \\
\text { Date }\end{array}$ \\
\hline CRR-6 & Columbia River & \begin{tabular}{|l} 
Biomonitoring/ \\
biomarkers for \\
key species
\end{tabular} & $\begin{array}{l}\text { Identify and characterize biological } \\
\text { sentinels that are influenced by } \\
\text { contaminants and are indicative of } \\
\text { environmental stressors. Develop } \\
\text { techniques for indicators of biological } \\
\text { uptake and impact, e.g., molecular } \\
\text { probes, sensor system for measuring } \\
\text { contaminant induced stress in aquatic } \\
\text { systems using mRNA. }\end{array}$ & River Corridor & \begin{tabular}{|l|} 
River Monitoring \\
Project, Integration \\
Project COS and SAC
\end{tabular} & \begin{tabular}{|l} 
River Corridor \\
Project (CERCLA \\
5-Year Review)
\end{tabular} & $10 / 04$ & $9 / 06$ \\
\hline CRR-7 & \begin{tabular}{|l} 
Ecological Risk \\
Assessment
\end{tabular} & $\begin{array}{l}\text { Biological Fate } \\
\text { and Transport }\end{array}$ & $\begin{array}{l}\text { The scope of this activity is to quantify } \\
\text { the changes in uptake (absorption) factors } \\
\text { of gut versus gill (or lung) versus dermis } \\
\text { when concentrations in one exposure } \\
\text { medium are varied independently of other } \\
\text { media. This will be used to reduce } \\
\text { uncertainties in multimedia contaminant } \\
\text { pharmacokinetic uptake models. The } \\
\text { outcome will be a set of functions for } \\
\text { multimedia contaminant uptake for } \\
\text { selected species and contaminants. Work } \\
\text { is currently being completed on aquatic } \\
\text { organisms and technetium-99, and work } \\
\text { on strontium-90 is to start in late FY02. } \\
\text { Next contaminants of interest are } \\
\text { iodine-129, chromium, and uranium. }\end{array}$ & River Corridor, Central Plateau & \begin{tabular}{|l|} 
Public Safety and \\
Resource Protection \\
Project, 100/300 Area \\
Remedial Action \\
Project, 200 Area \\
Remedial Action \\
Project, NRTC \\
Hanford Reach \\
Investigations, \\
Integration Project \\
COS and SAC
\end{tabular} & $\begin{array}{l}\text { COS and SAC } \\
\text { (technetium- } 99 \text { in } \\
7 / 02, \text { strontium-90 } \\
\text { in 7/03, iodine-129 } \\
\text { in 9/04) }\end{array}$ & $10 / 02$ & $9 / 04$ \\
\hline
\end{tabular}


Table 4.3 (Contd)

\begin{tabular}{|c|c|c|c|c|c|c|c|c|}
\hline Id No. & S\&T Activity & Descriptive Title & Brief Scope and Outcome & Hanford Site PBS & Interacts With & Product To & \begin{tabular}{|l} 
Desired \\
Start \\
Date of \\
S\&T \\
Activity
\end{tabular} & $\begin{array}{l}\text { Product } \\
\text { Delivery } \\
\text { Date }\end{array}$ \\
\hline CRR-8 & \begin{tabular}{|l} 
Ecological Risk \\
Assessment
\end{tabular} & $\begin{array}{l}\text { Modifiers to } \\
\text { Exposure }\end{array}$ & $\begin{array}{l}\text { The scope of this activity is to quantify } \\
\text { the bioavailability of selected Hanford } \\
\text { Site contaminants to representative } \\
\text { Columbia River species (riparian and } \\
\text { aquatic). This may include examination } \\
\text { of root exudates on plant uptake from } \\
\text { soils and groundwater, effects of } \\
\text { complexants on gut and gill absorption, } \\
\text { effects of dietary sorbants on gut } \\
\text { absorption, metal speciation and } \\
\text { complexation effects on gill and dermal } \\
\text { absorption, etc. The outcome will be a } \\
\text { documented database of bioavailability } \\
\text { for technetium-99, strontium-90, } \\
\text { iodine-129 and chromium and } \\
\text { representative Columbia River species } \\
\text { under likely environmental conditions. }\end{array}$ & River Corridor, Central Plateau & \begin{tabular}{|l|} 
Public Safety and \\
Resource Protection \\
Project, 100/300 Area \\
Remedial Action \\
Project, 200 Area \\
Remedial Action \\
Project, NRTC \\
Hanford Reach \\
Investigations, \\
Integration Project \\
COS and SAC
\end{tabular} & COS and SAC & $10 / 04$ & $9 / 06$ \\
\hline CRR-9 & $\begin{array}{l}\text { Human Health } \\
\text { Risk } \\
\text { Assessment }\end{array}$ & \begin{tabular}{|l|} 
Contaminant \\
Bioavailability in \\
the Environment
\end{tabular} & $\begin{array}{l}\text { The scope of this activity is to determine } \\
\text { the role of speciation, absorption, } \\
\text { complexation, and other environmental } \\
\text { factors on availability of selected } \\
\text { contaminants for human uptake. The } \\
\text { transformation of chemical compounds, } \\
\text { chemical speciation, and environmental } \\
\text { consideration impacts on human uptake } \\
\text { will be studied. The outcome will be a } \\
\text { database of bioavailabilities of selected } \\
\text { Hanford Site contaminants under likely } \\
\text { environmental conditions. }\end{array}$ & River Corridor, Central Plateau & $\begin{array}{l}\text { Integration Project } \\
\text { COS and SAC, 200 } \\
\text { Area Remedial Action } \\
\text { Project, 100/300 Area } \\
\text { Remedial Action } \\
\text { Project }\end{array}$ & \begin{tabular}{|l} 
SAC and COS \\
\end{tabular} & $10 / 05$ & 9/07 \\
\hline
\end{tabular}


Table 4.3 (Contd)

\begin{tabular}{|c|c|c|c|c|c|c|c|c|}
\hline Id No. & S\&T Activity & $\begin{array}{l}\text { Descriptive } \\
\text { Title }\end{array}$ & Brief Scope and Outcome & Hanford Site PBS & Interacts With & Product To & \begin{tabular}{|l} 
Desired \\
Start \\
Date of \\
S\&T \\
Activity \\
\end{tabular} & $\begin{array}{l}\text { Product } \\
\text { Delivery } \\
\text { Date }\end{array}$ \\
\hline CRR-10 & $\begin{array}{l}\text { Human Health } \\
\text { Risk } \\
\text { Assessment }\end{array}$ & \begin{tabular}{|l|} 
Food Chain \\
Transfer Factors \\
\\
\end{tabular} & $\begin{array}{l}\text { The scope of this activity is to develop } \\
\text { transfer factors that link biological or } \\
\text { abiotic concentrations of selected } \\
\text { Hanford Site contaminants to } \\
\text { bioavailability specific to human intake. } \\
\text { This will involve synthesizing existing } \\
\text { data as well as research on non- } \\
\text { agricultural products used by Native } \\
\text { Americans. The focus will be on how } \\
\text { food processing (cooking, pickling, } \\
\text { drying, etc.) impacts the concentrations } \\
\text { of contaminants in food products. The } \\
\text { outcome will be a documented database } \\
\text { of food-chain transfer factors. }\end{array}$ & River Corridor, Central Plateau & \begin{tabular}{|l|} 
COS and SAC, 200 \\
Area Remedial Action \\
Project, 100/300 Area \\
Remedial Action \\
Project, NRTC \\
Hanford Reach \\
Investigations
\end{tabular} & COS and SAC & $10 / 06$ & $9 / 07$ \\
\hline CRR-11 & $\begin{array}{l}\text { General Risk } \\
\text { Assessment }\end{array}$ & $\begin{array}{l}\text { Quantification of } \\
\text { Risk Decision } \\
\text { Metrics }\end{array}$ & $\begin{array}{l}\text { The scope of this activity is to develop } \\
\text { processes to quantify the impacts of } \\
\text { groundwater and river contamination on } \\
\text { various human and ecological receptors. } \\
\text { This task will develop a consistent metric } \\
\text { upon which to determine impacts that are } \\
\text { useful in the decision-making process } \\
\text { and reflective of appropriate receptor } \\
\text { groups. }\end{array}$ & River Corridor, Central Plateau & \begin{tabular}{|l|} 
COS and SAC,, 200 \\
Area Remedial Action \\
Project, 100/300 Area \\
Remedial Action \\
Project
\end{tabular} & COS and SAC & $10 / 06$ & $9 / 07$ \\
\hline
\end{tabular}


Table 4.4. Schedule and Products for Remediation Technical Element

\begin{tabular}{|c|c|c|c|c|c|c|c|c|}
\hline Id No. & S\&T Activity & Descriptive Title & Brief Scope and Outcome & Hanford Site PBS & Interacts With & Product To & $\begin{array}{c}\text { Desired } \\
\text { Start } \\
\text { Date of } \\
\text { S\&T } \\
\text { Activity }\end{array}$ & $\begin{array}{c}\text { Product } \\
\text { Delivery } \\
\text { Date }\end{array}$ \\
\hline Rem-1 & $\begin{array}{l}\text { Strontium-90 } \\
\text { Remediation }\end{array}$ & $\begin{array}{l}\text { Monitored Natural } \\
\text { Attenuation for } \\
\text { strontium-90 at } \\
100-\mathrm{N}\end{array}$ & $\begin{array}{l}\text { The scope of this activity is to evaluate } \\
\text { data to determine the fate and transport of } \\
\text { strontium- } 90 \text { through vadose zone and } \\
\text { groundwater in support of Monitored } \\
\text { Natural Attenuation (MNA) or } \\
\text { development of alternative concentration } \\
\text { limits at } 100-\mathrm{N} \text { Area. }\end{array}$ & \begin{tabular}{|l|} 
Central Plateau (Groundwater) \\
\end{tabular} & $\begin{array}{l}100 \text { Area Remedial } \\
\text { Action Project, EMSP }\end{array}$ & $\begin{array}{l}100 \text { Area Remedial } \\
\text { Action Project }\end{array}$ & $10 / 02$ & $9 / 07$ \\
\hline Rem-2 & $\begin{array}{l}\text { Strontium-90 } \\
\text { Remediation }\end{array}$ & $\begin{array}{l}\text { Phytoremediation } \\
\text { for strontium-90 at } \\
100-\mathrm{N}\end{array}$ & $\begin{array}{l}\text { Provide information on species selection } \\
\text { and description of biophysical processes } \\
\text { to support possible phytoremediation of } \\
\text { strontium- } 90 \text { at } 100 \text {-N Area. Evaluate if } \\
\text { controls can be put in place to prevent } \\
\text { transfer of contaminant from plants to } \\
\text { humans/animals. The scope includes site- } \\
\text { specific laboratory (greenhouse) studies } \\
\text { and field studies. }\end{array}$ & Central Plateau (Groundwater) & $\begin{array}{l}100 \text { Area Remedial } \\
\text { Action Project }\end{array}$ & $\begin{array}{l}100 \text { Area Remedial } \\
\text { Action Project }\end{array}$ & $10 / 02$ & $9 / 07$ \\
\hline Rem-3 & $\begin{array}{l}\text { Strontium-90 } \\
\text { Remediation }\end{array}$ & $\begin{array}{l}\text { Immobilization of } \\
\text { strontium-90 at } \\
100-\mathrm{N}\end{array}$ & $\begin{array}{l}\text { The scope of this activity is to provide } \\
\text { data and understanding of immobilization } \\
\text { of strontium- } 90 \text { (technetium-99 and } \\
\text { chromium) through injection of } \\
\text { phosphate chemicals, urea chemicals, and } \\
\text { calcium citrate. The scope includes } \\
\text { investigation of processes affecting the } \\
\text { delivery of chemicals, kinetics of the } \\
\text { reactions, and stability of the remediation. }\end{array}$ & \begin{tabular}{|l|} 
Central Plateau (Groundwater) \\
\end{tabular} & $\begin{array}{l}100 \text { Area Remedial } \\
\text { Action Project }\end{array}$ & $\begin{array}{l}100 \text { Area Remedial } \\
\text { Action Project }\end{array}$ & $10 / 02$ & $9 / 07$ \\
\hline Rem-4 & $\begin{array}{l}\text { Chromium } \\
\text { Remediation }\end{array}$ & $\begin{array}{l}\text { In situ gaseous } \\
\text { reduction of } \\
\text { chromium }\end{array}$ & $\begin{array}{l}\text { The scope of this activity is to evaluate } \\
\text { in situ gaseous reduction technology for } \\
\text { treatment of chromium(VI) in the vadose } \\
\text { zone in the } 100 \text { areas, contingent on } \\
\text { finding a vadose-zone source of } \\
\text { chromium contamination. The scope } \\
\text { includes evaluation of the application } \\
\text { rates and a better understanding of } \\
\text { geology at the site, which may affect } \\
\text { overall effectiveness of } \mathrm{H}_{2} \mathrm{~S} \\
\text { immobilization of chromium(VI). }\end{array}$ & River Corridor & $\begin{array}{l}100 \text { Area Remedial } \\
\text { Action Project }\end{array}$ & $\begin{array}{l}100 \text { Area Remedial } \\
\text { Action Project }\end{array}$ & $10 / 05$ & $9 / 07$ \\
\hline
\end{tabular}


Table 4.4 (Contd)

\begin{tabular}{|c|c|c|c|c|c|c|c|c|}
\hline Id No. & S\&T Activity & $\begin{array}{c}\text { Descriptive } \\
\text { Title }\end{array}$ & Brief Scope and Outcome & Hanford Site PBS & Interacts With & Product To & $\begin{array}{c}\text { Desired } \\
\text { Start } \\
\text { Date of } \\
\text { S\&T } \\
\text { Activity } \\
\end{array}$ & $\begin{array}{l}\text { Product } \\
\text { Delivery } \\
\text { Date }\end{array}$ \\
\hline Rem-5 & \begin{tabular}{|l|} 
Chromium \\
Remediation
\end{tabular} & \begin{tabular}{|l|} 
Reduction of \\
chromium (IV) \\
in the vadose \\
zone by gaseous \\
or liquid \\
reactants
\end{tabular} & $\begin{array}{l}\text { The scope of this activity is to evaluate the } \\
\text { potential for reduction of chromium in the } \\
\text { vadose zone by reactive solutions } \\
\text { containing sulfite, thiosulfate, dithionite, } \\
\text { or stannous chloride and reactive gases } \\
\text { such as } \mathrm{SO}_{2} \text {. Alternate approaches need to } \\
\text { evaluate reaction kinetics, effectiveness of } \\
\text { the reactions, formation of by-products, } \\
\text { delivery issues, effects of geology on } \\
\text { distribution, and for liquid systems, } \\
\text { mobilization of byproducts and/or } \\
\text { chromium(VI) at the spent reagent front. }\end{array}$ & River Corridor & $\begin{array}{l}100 \text { Area Remedial } \\
\text { Action Project }\end{array}$ & $\begin{array}{l}100 \text { Area Remedial } \\
\text { Action Project }\end{array}$ & $10 / 05$ & 9/07 \\
\hline Rem-6 & \begin{tabular}{|l} 
Chromium \\
Remediation
\end{tabular} & $\begin{array}{l}\text { Bioremediation } \\
\text { of chromium, } \\
\text { technetium- } 99, \\
\text { and uranium in } \\
\text { vadose zone and } \\
\text { groundwater }\end{array}$ & $\begin{array}{l}\text { The scope of this activity is to evaluate the } \\
\text { use of bioremediation to reduce chromium } \\
\text { (VI) by identifying locations at the } \\
\text { Hanford Site where bioremediation is } \\
\text { feasible and determining amendments that } \\
\text { can be used to stimulate bioremediation in } \\
\text { these environments. The DOE NABIR } \\
\text { program and other research are providing } \\
\text { general information for chromium } \\
\text { bioremediation. Site-specific reactions } \\
\text { and implementation designs need to be } \\
\text { investigated. }\end{array}$ & $\begin{array}{l}\text { River Corridor (vadose zone); } \\
\text { Central Plateau (Groundwater) }\end{array}$ & $\begin{array}{l}100 \text { and } 300 \text { Area } \\
\text { Remedial Action } \\
\text { Projects, } 200 \text { Area } \\
\text { Remedial Action } \\
\text { Project, Groundwater } \\
\text { Project (DOE NABIR } \\
\text { lead) }\end{array}$ & \begin{tabular}{|l|}
100 Area Remedial \\
Action Project, \\
200 Area Remedial \\
Action Project, \\
Groundwater \\
Management \\
Project
\end{tabular} & $10 / 05$ & 9/07 \\
\hline Rem-7 & \begin{tabular}{|l} 
Chromium \\
Remediation
\end{tabular} & $\begin{array}{l}\text { Reduction of } \\
\text { ISRM costs }\end{array}$ & $\begin{array}{l}\text { The scope of this activity is to evaluate } \\
\text { alternative approaches for deploying the } \\
\text { In Situ REDOX Manipulation (ISRM) } \\
\text { subsurface barrier, including studies to } \\
\text { justify leaving reagent in aquifer, modified } \\
\text { or alternative delivery methods (e.g. } \\
\text { nanoparticles, colloidal iron, bimetallic } \\
\text { particles, etc.), consider the addition of } \\
\text { amendments (dithionite) to existing pump- } \\
\text { and-treat process water and adding } \\
\text { extenders to increase the longevity of the } \\
\text { reducing zone. }\end{array}$ & Central Plateau (Groundwater) & Groundwater Project & $\begin{array}{l}\text { Groundwater } \\
\text { Project }\end{array}$ & $10 / 04$ & 9/06 \\
\hline
\end{tabular}


Table 4.4 (Contd)

\begin{tabular}{|c|c|c|c|c|c|c|c|c|}
\hline Id No. & S\&T Activity & $\begin{array}{c}\text { Descriptive } \\
\text { Title }\end{array}$ & Brief Scope and Outcome & Hanford Site PBS & Interacts With & Product To & $\begin{array}{c}\text { Desired } \\
\text { Start } \\
\text { Date of } \\
\text { S\&T } \\
\text { Activity }\end{array}$ & $\begin{array}{c}\text { Product } \\
\text { Delivery } \\
\text { Date }\end{array}$ \\
\hline Rem-8 & $\begin{array}{l}\text { Technetium-99 } \\
\text { and Uranium } \\
\text { Remediation }\end{array}$ & $\begin{array}{l}\text { Reduction and } \\
\text { immobilization } \\
\text { of technetium-99 } \\
\text { and uranium }\end{array}$ & $\begin{array}{l}\text { The scope of this activity is to evaluate } \\
\text { reduction and immobilization methods for } \\
\text { the treatment of technetium-99 and } \\
\text { uranium in the vadose zone and } \\
\text { groundwater. The most promising } \\
\text { methods should be evaluated in tests that } \\
\text { simulate field conditions. Evaluation } \\
\text { criteria should include the reaction } \\
\text { kinetics, stability of immobilized phases, } \\
\text { and delivery methods. The most } \\
\text { promising methods for consideration } \\
\text { include reduction by reducing gases, } \\
\text { liquids and colloidal solids, and } \\
\text { adsorption by phosphate minerals and } \\
\text { engineered particles, such as Self } \\
\text { Assembled Mesoporous Membranes } \\
\text { (SAMMS). }\end{array}$ & Central Plateau (Groundwater) & $\begin{array}{l}200 \text { and } 300 \text { Area } \\
\text { Remedial Action } \\
\text { projects, Groundwater } \\
\text { Project }\end{array}$ & $\begin{array}{l}\text { Groundwater } \\
\text { Management } \\
\text { Project }\end{array}$ & $10 / 03$ & 9/05 \\
\hline Rem-9 & $\begin{array}{l}\text { Technetium-99 } \\
\text { and Uranium } \\
\text { Remediation }\end{array}$ & $\begin{array}{l}\text { Bioremediation } \\
\text { of technetium-99 } \\
\text { and uranium }\end{array}$ & $\begin{array}{l}\text { The scope of this activity is to provide a } \\
\text { pilot field test site of approaches to } \\
\text { bioremediation of metals and } \\
\text { radionuclides based on promising research } \\
\text { projects that are part of the NABIR and } \\
\text { EMSP research portfolios. The scope will } \\
\text { include links with ongoing NABIR } \\
\text { laboratory work and activities at the Oak } \\
\text { Ridge National Laboratory Field Research } \\
\text { Center. }\end{array}$ & Central Plateau (Groundwater) & $\begin{array}{l}200 \text { and } 300 \text { Area } \\
\text { Remedial Action } \\
\text { projects, Groundwater } \\
\text { Project (DOE NABIR } \\
\text { lead) }\end{array}$ & $\begin{array}{l}\text { Groundwater } \\
\text { Management } \\
\text { Project }\end{array}$ & $10 / 03$ & $9 / 05$ \\
\hline
\end{tabular}


Table 4.4 (Contd)

\begin{tabular}{|c|c|c|c|c|c|c|c|c|}
\hline Id No. & S\&T Activity & $\begin{array}{l}\text { Descriptive } \\
\text { Title }\end{array}$ & Brief Scope and Outcome & Hanford Site PBS & Interacts With & Product To & $\begin{array}{l}\text { Desired } \\
\text { Start } \\
\text { Date of } \\
\text { S\&T } \\
\text { Activity }\end{array}$ & $\begin{array}{c}\text { Product } \\
\text { Delivery } \\
\text { Date }\end{array}$ \\
\hline Rem-10 & $\begin{array}{l}\text { Chromium, } \\
\text { Technetium-99, } \\
\text { and Uranium } \\
\text { Remediation }\end{array}$ & \begin{tabular}{|l} 
Develop \\
injection \\
techniques for \\
colloidal \\
particles
\end{tabular} & $\begin{array}{l}\text { The scope of this activity is to develop } \\
\text { injection techniques for extremely small } \\
\text { colloidal particles. Examples of particles } \\
\text { for injection are reactive substances, such } \\
\text { as iron and bi-metal particles, to establish } \\
\text { subsurface reactive barriers, biological } \\
\text { amendments for bioremediation, self } \\
\text { assembled mesoporous membrane } \\
\text { (SAMMS) particles for adsorption, and } \\
\text { other particles that alter the } \\
\text { electromagnetic properties of the earth for } \\
\text { characterization and leak detection. } \\
\text { Evaluate long-term stability of particles } \\
\text { and delivery methods for injection and } \\
\text { placement. Contaminant targets include } \\
\text { chromium, technetium- } 99 \text {, and uranium. }\end{array}$ & Central Plateau (Groundwater) & $\begin{array}{l}\text { Groundwater Project, } \\
\text { EMSP }\end{array}$ & $\begin{array}{l}\text { Groundwater } \\
\text { Project }\end{array}$ & $10 / 03$ & $9 / 05$ \\
\hline Rem-11 & $\begin{array}{l}\text { Carbon } \\
\text { Tetrachloride } \\
\text { Remediation }\end{array}$ & $\begin{array}{l}\text { Characterization } \\
\text { technologies for } \\
\text { carbon } \\
\text { tetrachloride }\end{array}$ & $\begin{array}{l}\text { The scope of this activity is to evaluate } \\
\text { characterization technologies for carbon } \\
\text { tetrachloride in the vadose zone and } \\
\text { groundwater. Consideration will be given } \\
\text { to deep access technologies and rapid, } \\
\text { cost-effective detection methods. } \\
\text { Characterization technologies that have } \\
\text { been developed or improved by EM-50 } \\
\text { include the cone penetrometer wireline } \\
\text { sampler and wireline grouting module, } \\
\text { gas-sample probe, instrumented cone, } \\
\text { Membrane Interface Probe (MIP), } \\
\text { HaloSnif, Laser Induced Fluorescence and } \\
\text { Raman probe, and Ribbon NAPL sampler. }\end{array}$ & \begin{tabular}{|l} 
Central Plateau \\
\end{tabular} & $\begin{array}{l}200 \text { Area Remedial } \\
\text { Action Project, } \\
\text { Groundwater Project, } \\
\text { EMSP, EM-50 }\end{array}$ & $\begin{array}{l}200 \text { Area Remedial } \\
\text { Action Project, } \\
\text { Groundwater } \\
\text { Project }\end{array}$ & $10 / 02$ & $9 / 04$ \\
\hline
\end{tabular}


Table 4.4 (Contd)

\begin{tabular}{|c|c|c|c|c|c|c|c|c|}
\hline Id No. & S\&T Activity & $\begin{array}{c}\text { Descriptive } \\
\text { Title }\end{array}$ & Brief Scope and Outcome & Hanford Site PBS & Interacts With & Product To & $\begin{array}{c}\text { Desired } \\
\text { Start } \\
\text { Date of } \\
\text { S\&T } \\
\text { Activity } \\
\end{array}$ & $\begin{array}{c}\begin{array}{c}\text { Product } \\
\text { Delivery } \\
\text { Date }\end{array} \\
\end{array}$ \\
\hline Rem-12 & $\begin{array}{l}\text { Carbon } \\
\text { Tetrachloride } \\
\text { Remediation }\end{array}$ & $\begin{array}{l}\text { Steam-Injection } \\
\text { for Remediation } \\
\text { of carbon } \\
\text { tetrachloride }\end{array}$ & $\begin{array}{l}\text { The scope of this activity is to evaluate } \\
\text { steam injection to the vadose zone for } \\
\text { remediation of carbon tetrachloride } \\
\text { source-treatment technology. A key issue } \\
\text { is the cost of steam injection-point } \\
\text { installation. Investigation of alternative } \\
\text { access for steam injection is needed. } \\
\text { Determining how steam could be } \\
\text { implemented with respect to the Plio- } \\
\text { Pleistocene layer, and contaminant } \\
\text { distribution is needed. A review of } \\
\text { information gathered for the ITRD project } \\
\text { should be used to guide additional } \\
\text { investigations. }\end{array}$ & Central Plateau & $\begin{array}{l}200 \text { Area Remedial } \\
\text { Action Project }\end{array}$ & $\begin{array}{l}200 \text { Area Remedial } \\
\text { Action Project }\end{array}$ & $10 / 04$ & $9 / 06$ \\
\hline Rem-13 & $\begin{array}{l}\text { Carbon } \\
\text { Tetrachloride } \\
\text { Remediation }\end{array}$ & $\begin{array}{l}\text { Six-Phase } \\
\text { Heating for } \\
\text { carbon } \\
\text { tetrachloride } \\
\text { remediation }\end{array}$ & $\begin{array}{l}\text { The scope of this activity is to evaluate } \\
\text { six-phase heating for remediation of } \\
\text { carbon tetrachloride in the vadose zone. } \\
\text { A key issue is the cost of installing } \\
\text { electrodes. Investigation of alternative } \\
\text { electrode installation as proposed to the } \\
\text { ITRD is needed. A review of information } \\
\text { gathered for the ITRD project should be } \\
\text { used to guide additional investigations. } \\
\end{array}$ & Central Plateau & $\begin{array}{l}200 \text { Area Remedial } \\
\text { Action Project }\end{array}$ & $\begin{array}{l}200 \text { Area Remedial } \\
\text { Action Project }\end{array}$ & $10 / 05$ & $9 / 07$ \\
\hline Rem-14 & $\begin{array}{l}\text { Carbon } \\
\text { Tetrachloride } \\
\text { Remediation }\end{array}$ & $\begin{array}{l}\text { Control of } \\
\text { carbon } \\
\text { tetrachloride } \\
\text { groundwater } \\
\text { plume }\end{array}$ & $\begin{array}{l}\text { Evaluate alternatives for containment and } \\
\text { control of the carbon tetrachloride } \\
\text { groundwater plume. This activity requires } \\
\text { coordination with the Groundwater } \\
\text { Project to identify remediation } \\
\text { alternatives that require S\&T investment. } \\
\text { S\&T will assist with modeling evaluations } \\
\text { of technology alternatives. }\end{array}$ & Central plateau & Groundwater Project & $\begin{array}{l}\text { Groundwater } \\
\text { Project }\end{array}$ & $10 / 03$ & $9 / 04$ \\
\hline
\end{tabular}


Table 4.4 (Contd)

\begin{tabular}{|c|c|c|c|c|c|c|c|c|}
\hline Id No. & S\&T Activity & $\begin{array}{c}\text { Descriptive } \\
\text { Title }\end{array}$ & Brief Scope and Outcome & Hanford Site PBS & Interacts With & Product To & $\begin{array}{l}\text { Desired } \\
\text { Start } \\
\text { Date of } \\
\text { S\&T } \\
\text { Activity } \\
\end{array}$ & $\begin{array}{c}\text { Product } \\
\text { Delivery } \\
\text { Date }\end{array}$ \\
\hline Rem-15 & \begin{tabular}{|l|} 
Carbon \\
Tetrachloride \\
Remediation
\end{tabular} & \begin{tabular}{|l|} 
Evaluate \\
degradation of \\
carbon \\
tetrachloride for \\
Monitored \\
Natural \\
Attenuation \\
\end{tabular} & $\begin{array}{l}\text { The scope of this activity is to identify } \\
\text { mechanisms that degrade carbon } \\
\text { tetrachloride contamination. The scope } \\
\text { will include evaluation of biotic and } \\
\text { abiotic degradation of carbon tetrachloride } \\
\text { in the vadose zone and groundwater } \\
\text { through laboratory experiments under } \\
\text { ambient conditions. Evaluate } \\
\text { bioremediation and biostimulation } \\
\text { methods for carbon tetrachloride. }\end{array}$ & Central Plateau & $\begin{array}{l}\text { Groundwater Project, } \\
\text { 200 Area Remedial } \\
\text { Action Project }\end{array}$ & $\begin{array}{l}\text { Groundwater } \\
\text { Project, } 200 \text { Area } \\
\text { Remedial Action } \\
\text { Project }\end{array}$ & $10 / 04$ & $9 / 05$ \\
\hline Rem-16 & $\begin{array}{l}\text { Surface Barrier } \\
\text { Technology }\end{array}$ & \begin{tabular}{|l|} 
RCRA \\
Modified C \\
Surface Barrier
\end{tabular} & $\begin{array}{l}\text { Construct and instrument an RCRA- } \\
\text { Modified C surface barrier. EM-50 } \\
\text { support is needed through ASTD and } \\
\text { long-term monitoring systems. Perform } \\
3 \text { years of monitoring to complete the } \\
\text { field treatability test }\end{array}$ & Central Plateau & $\begin{array}{l}200 \text { Area Remedial } \\
\text { Action Project (lead), } \\
\text { Tank farm closure } \\
\text { project, ILAW }\end{array}$ & $\begin{array}{l}200 \text { Area Remedial } \\
\text { Action Project, } \\
\text { Tank farm closure } \\
\text { project. ILAW }\end{array}$ & $10 / 05$ & 9/08 \\
\hline Rem-17 & $\begin{array}{l}\text { Surface Barrier } \\
\text { Technology }\end{array}$ & \begin{tabular}{|l|} 
Surface Barrier \\
Monitoring \\
Technologies \\
\\
\end{tabular} & $\begin{array}{l}\text { Technologies are needed for cost- } \\
\text { effective, long-term, and large-scale } \\
\text { evaluation of barrier hydrologic } \\
\text { performance, both within the barrier } \\
\text { system and below the barrier. Methods } \\
\text { should be non-intrusive or installed during } \\
\text { construction, automatic, robust and } \\
\text { durable. Ground-penetrating radar, } \\
\text { profiling TDR, and measurement of water } \\
\text { flux have been tested for application to } \\
\text { surface-barrier monitoring. Additional } \\
\text { technologies will be evaluated and } \\
\text { incorporated into design of the RCRA- } \\
\text { Modified C surface barrier. }\end{array}$ & \begin{tabular}{|c|} 
Central Plateau \\
\end{tabular} & $\begin{array}{l}200 \text { Area Remedial } \\
\text { Action Project, Tank } \\
\text { farm closure project, } \\
\text { ILAW }\end{array}$ & $\begin{array}{l}200 \text { Area Remedial } \\
\text { Action Project, } \\
\text { Tank farm closure } \\
\text { project, ILAW }\end{array}$ & $10 / 02$ & $9 / 04$ \\
\hline
\end{tabular}


Table 4.4 (Contd)

\begin{tabular}{|c|c|c|c|c|c|c|c|c|}
\hline Id No. & S\&T Activity & $\begin{array}{c}\text { Descriptive } \\
\text { Title }\end{array}$ & Brief Scope and Outcome & Hanford Site PBS & Interacts With & Product To & $\begin{array}{c}\text { Desired } \\
\text { Start } \\
\text { Date of } \\
\text { S\&T } \\
\text { Activity }\end{array}$ & $\begin{array}{c}\begin{array}{c}\text { Product } \\
\text { Delivery } \\
\text { Date }\end{array} \\
\end{array}$ \\
\hline Rem-18 & $\begin{array}{l}\text { Surface-Barrier } \\
\text { Technology }\end{array}$ & $\begin{array}{l}\text { Surface-barrier } \\
\text { studies of plant } \\
\text { ecology }\end{array}$ & $\begin{array}{l}\text { Evaluate the ecology of surface barriers to } \\
\text { optimize barrier performance. Evaluate } \\
\text { impacts of plants on surface infiltration } \\
\text { (macropores from roots), the effects of } \\
\text { wild fires, wind erosion, and deposition. }\end{array}$ & Central Plateau & $\begin{array}{l}200 \text { Area Remedial } \\
\text { Action Project, Tank } \\
\text { farm closure project, } \\
\text { ILAW }\end{array}$ & $\begin{array}{l}200 \text { Area Remedial } \\
\text { Action Project, } \\
\text { Tank farm closure } \\
\text { project, ILAW }\end{array}$ & $10 / 03$ & $9 / 06$ \\
\hline Rem-19 & $\begin{array}{l}\text { Surface-Barrier } \\
\text { Technology }\end{array}$ & $\begin{array}{l}\text { Surface-barrier } \\
\text { side-slope } \\
\text { issues }\end{array}$ & $\begin{array}{l}\text { Evaluate side-slope stability and edge } \\
\text { effects. This activity includes analyses of } \\
\text { the hydrologic edge effects of side slopes } \\
\text { that use coarse materials, such as gravel or } \\
\text { large rocks, for slope stability to increase } \\
\text { infiltration, and will be important for } \\
\text { waste sites where an above-grade } \\
\text { component will remain and large volumes } \\
\text { of side-slope drainage will need to be } \\
\text { managed, e.g. Canyon disposition. }\end{array}$ & Central Plateau & $\begin{array}{l}200 \text { Area Remedial } \\
\text { Action Project, Tank } \\
\text { farm closure project }\end{array}$ & $\begin{array}{l}200 \text { Area Remedial } \\
\text { Action Project, } \\
\text { Canyon disposition } \\
\text { initiative }\end{array}$ & $10 / 04$ & $9 / 06$ \\
\hline Rem-20 & \begin{tabular}{|l} 
Surface-Barrier \\
Technology
\end{tabular} & $\begin{array}{l}\text { Surface-barrier } \\
\text { asphalt and } \\
\text { alternative } \\
\text { material } \\
\text { durability } \\
\text { testing }\end{array}$ & $\begin{array}{l}\text { Perform durability tests on the asphalt } \\
\text { layer planned for the Hanford surface } \\
\text { barrier. Evaluate alternative materials for } \\
\text { interim covers and their incorporation into } \\
\text { graded barrier designs. }\end{array}$ & Central Plateau & $\begin{array}{l}200 \text { Area Remedial } \\
\text { Action Project, Tank } \\
\text { farm closure project }\end{array}$ & $\begin{array}{l}200 \text { Area Remedial } \\
\text { Action Project }\end{array}$ & $10 / 05$ & $9 / 07$ \\
\hline $\begin{array}{l}\mathrm{CCl}_{4} \\
\mathrm{HLW} \\
\text { NABIR } \\
\text { PUREX } \\
\text { RFI } \\
\text { ROD } \\
\text { SST } \\
\text { TBD }\end{array}$ & \multicolumn{8}{|c|}{$\begin{array}{l}=\text { carbon tetrachloride } \\
=\text { high-level waste } \\
=\text { Natural and Accelerated Bioremediation Research Program } \\
=\text { Plutonium/Uranium Extraction Plant } \\
=\text { RCRA facility investigation } \\
=\text { Record of Decision } \\
=\text { single-shell tank } \\
=\text { to be determined }\end{array}$} \\
\hline
\end{tabular}




\subsection{Linkages to the Groundwater Protection Program and Core Projects}

This section of the roadmap briefly describes the needs associated with each of the core projects within the Groundwater Protection Program and the linkages to S\&T outcomes. The linkages to the Performance Management Plan for the Hanford Site are also discussed. The Groundwater Protection Program and core projects that receive products from S\&T include the following:

- System Assessment Capability and Characterization of Systems

- Tank Farm Vadose Zone Project

- 200 Area Remedial Action Project

- Groundwater Project (CERCLA 5-year review)

- Immobilized Low-Activity Waste (ILAW)

- Performance Management Plan.

For the S\&T Project to have an impact, it must deliver correct scientific and technical information in a timely manner to meet the Groundwater Protection Program and core project(s) objectives. Hence, the S\&T outcomes are based on the scope descriptions in Section 1.4 and ongoing discussions between scientists and the projects. The baselines and milestones may vary from these planning estimates, and S\&T activities will be adjusted to reflect these changes. In particular, the target schedule for S\&T input to the Integration Project and core projects defined in Table 5.1 was used to identify activities in advance of when the projects need the results. The key project dates are when the S\&T outcomes will be provided.

\subsection{Linkages with Site-Wide Assessments}

Site-Wide Assessment Project: S\&T activities linked to the site-wide assessments using the System Assessment Capability provide conceptual models, analytical and numerical models, data, and model parameters. The input from $S \& T$ to the site-wide assessments is developed through the Characterization of Systems Task of the Groundwater Protection Program.

The System Assessment Capability (SAC) is being refined and applied to perform site-wide assessments in support of remedial action and land-use decisions at the Hanford Site. It provides a suite of models and parameter databases that can be used by the Groundwater Protection Program to conduct

site-wide system assessments. The results of these assessments will be used to make decisions regarding operations, e.g., land use, and remediation at the Hanford Site, e.g., tank retrieval, 100, 200, and 300 Area soil site cleanup. In FY01, an initial assessment was completed with this capability. The SAC is an important end user of S\&T products. The site-wide assessments will require input from the inventory, vadose zone, groundwater, Columbia River, and risk assessment technical elements in the S\&T roadmap (as listed below). The input for the site-wide assessments is provided through the Characterization of 
Table 5.1. Schedules for Site-Wide Assessments and Core Projects

\begin{tabular}{|c|c|c|}
\hline Core Project & Project Activity & $\begin{array}{l}\text { Key Dates for } \\
\text { S\&T Input }\end{array}$ \\
\hline System Assessment Capability & Data Gathering for FY03 Assessment & Jun 03 \\
\hline \multirow{5}{*}{ RPP Vadose Zone Project } & $\begin{array}{l}\text { Field Investigation Report for S-SX Remedial } \\
\text { Feasibility Study }\end{array}$ & Complete \\
\hline & $\begin{array}{l}\text { Field Investigation Report for B-BX-BY Remedial } \\
\text { Feasibility Study }\end{array}$ & Jul 02 \\
\hline & $\begin{array}{l}\text { Field Investigation Report for T-TX-TY Remedial } \\
\text { Feasibility Study }\end{array}$ & Feb 04 \\
\hline & A-AX, C, U Field Investigation Reports & Feb 06 \\
\hline & Tank Closure Plans & Jun 04 \\
\hline \multirow{8}{*}{200 Area Remedial Action Project } & $\begin{array}{l}\text { PW-2 Uranium-rich waste group (uranium } \\
\text { mobility) }\end{array}$ & Apr 04 \\
\hline & CS-1 Chemical sewers waste group & Apr 04 \\
\hline & $\begin{array}{l}\text { PW-1 Plutonium/organic rich waste group (carbon } \\
\text { tetrachloride, plutonium mobility) }\end{array}$ & Apr 05 \\
\hline & LW-1 Laboratory waste group & Oct 05 \\
\hline & IS-1 Tanks/lines/pits waste group & Oct 05 \\
\hline & UR-1 Unplanned release waste group & Oct 05 \\
\hline & Burial ground waste group & Jul 07 \\
\hline & $\begin{array}{l}\text { Complete all } 200 \text { Area Soil Waste Site Assessment } \\
\text { pre-Record of Decision site investigations }\end{array}$ & Dec 08 \\
\hline CERCLA 5-Year Review & CERCLA 5-year review update & Jul 06 \\
\hline
\end{tabular}

Systems Task. (Note: A more complete description of the S\&T outcomes, interfaces, and schedules can be found in Section 4, Table 4.1 through Table 4.4. The Identification Numbers [Id. No.] for each S\&T outcome are listed in parentheses, below, to identify the S\&T outcomes [in Table 4.1 through Table 4.3] that provide input to the System Assessment Capability.)

- Develop models that provide a mass balance accounting of contaminant quantity, volume, and timing of releases, with uncertainties (inventory technical element; Id. No. Inv-1 through Inv-8).

- Develop conceptual models, numerical models, and parameters for fate and transport through the vadose zone that allow flux predictions of contaminants from vadose-zone sources to groundwater (subsurface transport; Id. No. ST-1 and 2; ST-4 through ST-6; ST-9; ST-12, and ST-18 through ST-20).

- Evaluate historical groundwater data to interpret three-dimensional groundwater plumes at the interface with the vadose zone to develop dispersivity estimates for key groundwater contaminants and collect depth-discrete data where tank leaks have impacted groundwater (subsurface transport technical element; Id. No. ST-19 and ST-20). 
- Collect data and develop methods for characterizing the groundwater-river interface to estimate contaminant discharge to the Columbia River under highly variable conditions caused by river-level fluctuations (subsurface transport technical element; Id. No. ST-21 through ST-23).

- Develop conceptual and numerical models of the Columbia River (Columbia River and risk technical element; Id. No. CRR-1 and CRR-3).

- Fill gaps for conducting ecological and human health risk assessments (Columbia River and risk technical element; Id. No. CRR-7 through CRR-12).

\subsection{Linkages with the Tank Farm Vadose Zone Project}

Tank Farm Vadose Zone Project: S\&T activities linked to the Tank Farm Vadose Zone Project provide conceptual models, analytical and numerical models, data, and model parameters.

The Tank Farm Vadose Zone Project is collecting field data to better assess the need for corrective measures that will mitigate the further migration of contaminants released from tanks or ancillary facilities. The goal of the Tank Farm Vadose Zone Project is to collect field data, perform evaluations, and develop understanding of the impacts of tank waste that affect decisions regarding tank-farm interim corrective actions, waste-retrieval options, and closure alternatives. As has been previously described, the S\&T provided extensive input to the Field Investigation Report for the S-SX Tank Farm and also has provided similar input to the FIR for the B-BX-BY Tank Farm. These reports are based on a combination of existing knowledge, results of new field-characterization activities, analyses, and simulations of contaminant transport. The Tank Farm Vadose Zone Project has also taken advantage of information developed by others, including results of the 200 Area Remedial Action Project, the RPP Immobilized Waste Project, and other outcomes generated by the Groundwater Protection Program. The S\&T activities described in this roadmap generally support this core project's schedule for field investigations at each tank farm group. For each tank farm, a field investigation report will be generated and will include relevant S\&T outcomes. (Note: A more complete description of the S\&T outcomes, interfaces, and schedules can be found in Section 4 [Table 4.1 through Table 4.4]. The Identification Numbers [Id. No.] for each S\&T outcome are listed in parentheses below to aid the reader in identifying S\&T outcomes [in Table 4.1 and Table 4.2] that provide input to the RPP.)

- Develop better models to estimate tank-leak losses (inventory technical element; Id. No. Inv-5 and Inv-6; RPP lead).

- Conduct investigations of materials (contaminated and uncontaminated sediment samples) from representative field sites to test alternative conceptual models to better understand the controlling contaminant-migration processes near leaked tanks and predict future migration; additionally, perform transport modeling simulations to evaluate these conceptual models (subsurface transport technical element; Id. No. ST-7 through ST-9; ST-11 and ST-12; ST-14 through ST-16).

- Carry out vadose-zone transport field studies at uncontaminated sites that allow reconciliation of conceptual models and facilitate validation/verification of transport models (subsurface transport technical element; Id. No. ST-1 through ST-4).

- Re-evaluate existing data from groundwater monitoring activities and conduct depth-discrete sampling in existing wells to collect additional data that describe the three-dimensional plume in the 
groundwater near the near-source discharge from the vadose zone to past tank leaks (subsurface transport technical element; Id. No. ST-18 through ST-20).

\title{
5.3 Linkages with the 200 Area Remedial Action Project
}

\author{
200 Area Remedial Action Project: S\&T activities linked to the 200 Area Remedial Action Project provide \\ conceptual models, analytical and numerical models, data, and model parameters to support \\ characterization and remedial design activities.
}

The characterization of the 200 Area waste-site groupings was initiated in FY99. The field characterization results must be analyzed to complete the TPA Major Milestone M-15-00C by December 2008 (TPA 1989). The TPA milestone requires that 200 Area non-tank farm operable unit remedial investigations to support Records of Decision be completed at that time. The S\&T activities described in this roadmap support the 200 Area Remedial Action project through the following activities. (Note: A more complete description of the S\&T outcomes, interfaces, and schedules can be found in Section 4 [Table 4.1 through Table 4.4]. The Id. No. for each S\&T outcome is listed in parentheses below to aid the reader in identifying the S\&T outcomes [in Table 4.1, Table 4.2, and Table 4.4] that provide input to the 200 Area Waste Sites Assessment.)

- Develop inventory models to estimate the quantity, volume, and timing of releases to the soil sites receiving plant cooling water, chemical sewer, scavenging waste, and surface spills (inventory technical element; Id. No. Inv-3, Inv-7 and Inv-8).

- Conduct investigations of materials (contaminated and uncontaminated sediment samples) from waste-site characterization to develop conceptual models to understand the controlling contaminant migration processes near 200 Area waste sites and to predict future migration (subsurface transport technical element); additionally, perform transport modeling simulations to evaluate these conceptual models (subsurface transport technical element; Id. No. ST-3 and 4; ST-7 and 8; ST-10; and ST-17).

- Conduct laboratory studies on Hanford sediments to investigate the extent of residual carbon tetrachloride saturation and irreversible sorption and degradation (subsurface transport technical element; Id. No. ST-13). These activities are linked to the DOE OST project to accelerate the baseline for remediation of carbon tetrachloride.

- Evaluate characterization and remediation technologies for carbon tetrachloride. The existing technologies for carbon tetrachloride characterization limit the extent of the investigations, and remediation technologies are needed (remediation technical element; Id. No. Rem 11 through Rem-15).

- Evaluate technologies for cost-effective and large-scale evaluation of surface-barrier hydrologic performance, support feasibility test for modified Hanford barrier to meet RCRA Modified C requirements, evaluate side-slope issues and asphalt or other barrier materials, and develop data to support optimal barrier design (remediation technical element; ID No. Rem 16 through Rem 20). 


\subsection{Linkages with the River Monitoring Project}

River Monitoring Project: S\&T activities will be integrated with the River Monitoring Project to assure that data and models can be used to determine monitoring requirements in the river to provide consistent input to the SAC.

The River Monitoring Project samples the Columbia River and the related environment to meet regulatory drivers. Results of river monitoring activities are used to determine compliance with applicable environmental standards and to evaluate the current impacts of Hanford Site operations on the river. Because the Columbia River is a key technical element within the SAC to evaluate potential impacts and consequences of migrating contaminants, as well as the assessment of potential risk, S\&T activities will be coordinated with the River Monitoring Project to obtain the needed data, parameters, and models. The following S\&T activities have been identified for coordination with the River Monitoring Project. (Note: A more complete description of the S\&T outcomes, interfaces, and schedules can be found in Section 4 [Table 4.1 through Table 4.4]. The Id. No. for each S\&T outcome is listed in parentheses below to aid the reader in identifying the S\&T outcomes [in Table 4.3] that provide input to the River Monitoring Project.)

- Investigate ecological and contaminant fate and transport in the river environment to support sitewide and site-specific risk assessments, including the evaluation of physical, chemical, and biological processes that reduce contaminant concentrations, mass, mobility, and/or toxicity at the groundwater/river interface (Columbia River and risk technical element; Id. No. CRR-1 and CRR-2).

- Develop and apply a contaminant transport model for the Hanford Reach of the Columbia River (SiteWide Assessment Task lead; Columbia River and risk technical element; Id. No. CRR-3).

- Evaluate geomorphic controls on the entrainment of river water in bed sediments and conduct field experiments to determine the impact of river water on pore water quality relative to groundwater flow at locations where contaminants are discharging to the river, e.g., strontium-90 at 100-N, uranium in the 300 Area, and chromium plumes - Columbia River and risk technical element; Id. No. CRR-4.

- Develop and deploy cost-effective, in situ monitoring instruments for water quality and biological impacts (Columbia River and risk technical element; Id. No. CRR-5 and CRR-6).

\subsection{Linkages with the ILAW Project}

Immobilized Low-Activity Waste (ILAW) Project: A selected set of S\&T activities may be conducted in conjunction with the field activities conducted for the ILAW to obtain key data or test models.

The RPP ILAW facilities, which will be located in the 200 East Area, will receive the low-activity waste form generated from treated and immobilized tank waste. The construction decision for this facility is scheduled for FY03. Current field and S\&T activities carried out as part of the ILAW project are directed at gathering the information needed to conduct performance assessments that support this decision, including data on geology, recharge rates, near-field and far-field hydraulic properties, and nearfield and far-field geochemical properties. The ILAW project is also gathering information on available contaminant transport codes and is working to define conceptual and numerical models. The Integration Project S\&T activities are not currently directly linked with ILAW project activities, but coordinate activities on: 
- wrap-around science (as appropriate) to obtain geology, near- and far-field hydrology, and near- and far-field geochemistry data that can be used in conceptual and numerical modeling to the mutual benefit of the ILAW project and the Integration Project site-wide assessment and S\&T activities

- reactive transport modeling to support both the ILAW project and the Integration Project.

\subsection{Linkages with the Performance Management Plan}

Performance Management Plan: S\&T activities will be coordinated with Strategic Initiative 6 of the Performance Management Plan (through the Groundwater Protection Program) to obtain key data to support alternative remediation strategies and develop monitoring approaches.

Hanford's groundwater is an important resource and the primary pathway for contaminants to reach the Columbia River. Strategic Initiative 6 of the Performance Management Plan will institute a set of actions to protect groundwater and the Columbia River by removing or isolating important contaminant sources on the Central Plateau, remediating contamination sources exterior to the Central Plateau core zone, reducing conditions that have the potential to drive contaminants into groundwater, and integrating groundwater monitoring. The focus of Strategic Initiative 6 is to accelerate actions for which technology is available and invest in S\&T where gaps exist to achieve groundwater protection. A group focused on identifying cleanup challenges and constraints (C3T) is developing a groundwater strategy that will specify actions needed to protect groundwater from further degradation, data needed to make sound remediation decisions, and activities and facilities needed to remediate existing groundwater plumes. The key elements of Strategic Initiative 6 include:

High Risk Source Control to take early actions to reduce the risk of large, mobile contaminant inventories from further degrading groundwater. Under the acceleration plan, the following groups of waste sites are identified for characterization and covering with surface barriers: 1) U Plant cribs and trenches, in conjunction with Strategic Initiative 5 to accelerate central plateau cleanup, 2) B/C cribs and trenches containing the largest estimated inventory of technetium-99 discharged to the vadose zone, 3) PUREX cribs and trenches that received high-volume condensates and wastes from operations, remaining as likely sources for continuing discharges of iodine-129 to groundwater, and 4) Plutonium Finishing Plant carbon tetrachloride waste sites to characterize the vadose zone and groundwater plumes of carbon tetrachloride and initiate remediation. The S\&T activities described in this roadmap support the Groundwater Protection Project's effort for high risk source control through the following activities. (Note: A more complete description of the S\&T outcomes, interfaces, and schedules can be found in Section 4 [Table 4.1 through Table 4.4]. The Id. No. for each S\&T outcome is listed in parentheses below to aid the reader in identifying the S\&T outcomes [in Table 4.2 and Table 4.4] that provide input to highrisk source control.)

- Conduct inventory estimation efforts to guide site characterization efforts (inventory technical element; Id. No. Inv-3 and 4), vadose-zone transport field study of uranium reactive transport (subsurface transport; Id. No. ST-2) and geochemical studies of uranium mobility and transport (subsurface transport; Id. No. ST-7, and ST-14 through ST-16).

- Evaluate reduction and immobilization of technetium-99 and uranium, including small colloidal particle injection and bioremediation (remediation technical element; Id. No. Rem-8 through Rem-10). 
- Conduct technology-development activities associated with testing and monitoring a modified Hanford barrier that meets RCRA Modified C requirements (remediation technical element; Id. No. 16 through 20).

Reduce Recharge Conditions to remove the driving force for contaminants to migrate through the vadose zone to the groundwater. Specific actions include decommissioning high-risk or unused wells near waste sites on the Central Plateau, reducing the potential for water-line leakage and the potential for breaks by reducing system pressure, inspecting and repairing portions of the water system near waste sites, constructing run-on/run-off control remedies at high-risk waste sites where water drainage is a problem, and rerouting septic discharges where they may be impacting waste sites. All of these actions are linked with characterizing recharge and measuring moisture conditions and water flux in the vadose zone. The S\&T activities described in this roadmap support the Groundwater Protection Project's effort to reduce recharge. (Note: A more complete description of the S\&T outcomes, interfaces, and schedules can be found in Section 4 [Table 4.1 through Table 4.4]. The Id. No. for each S\&T outcome is listed in parentheses below to aid the reader in identifying the S\&T outcomes [in Table 4.2] that provide input to reducing recharge, the driving force for contamination in the vadose zone.)

- Develop methods and technologies for the characterization and monitoring of subsurface moisture and contaminant plumes (subsurface transport; Id. No. ST-3).

- Provide improved estimates of recharge for the Hanford site using data from vadose-zone monitoring and field experiments (subsurface transport; Id. No. ST-4).

Shrink the Footprint of Contaminated Area to remediate and close groups of waste sites that are located outside the core zone of the Central Plateau by 2012, including the 200 North Area, Gable Mountain Pond/B Pond, the Non-Radioactive Dangerous Waste Landfill, and solid-waste landfills. The S\&T project will contribute to remediation and closure of these waste sites by updating conceptual models of key contaminants in these waste sites. (Note: A more complete description of the S\&T outcomes, interfaces, and schedules can be found in Section 4 [Table 4.1 through Table 4.4]. The Id. No. for each S\&T outcome is listed in parentheses below to aid the reader in identifying the S\&T outcomes [in Table 4.2] that provide input to shrinking the contaminated footprint at the Hanford Site.)

- Develop a geochemical reaction and transport model for strontium-90 that can be applied to 200 area soil waste sites (subsurface transport; Id. No. ST-8) in addition to tank farms.

- Conduct technology-development activities associated with testing and monitoring a modified Hanford barrier that meets RCRA Modified C requirements (remediation technical element; Id. No. 16 through 20).

Resolve Current Pump-and-Treat Operations to replace two of the five pump-and-treat systems operating at the Hanford Site, the 200-ZP-1 groundwater pump-and-treat system for carbon tetrachloride in the 200-West Area and the corresponding soil vapor extraction system (200ZP-2), and the pump-andtreat system for the strontium-90 plume in the 100-N Area. In addition, the S\&T Project will include research to address other contaminants, including chromium and technetium-99. (Note: A more complete description of the S\&T outcomes, interfaces, and schedules can be found in Section 4 [Table 4.1 through Table 4.4]. The Id. No. for each S\&T outcome is listed in parentheses below to aid the reader in identifying the S\&T outcomes [in Table 4.4] that provide input to resolving current pump-and-treat operations.) 
- Evaluate the feasibility of phytoremediation, immobilization technologies, and technologies and scientific results needed to support monitored natural attenuation or alternative concentration limits for strontium-90 at the 100-N Area (remediation technical element; Id. No. Rem-1 through Rem-3).

- Evaluate remediation technologies for remediation of chromium in the vadose zone and groundwater, including in situ gaseous reduction, other gaseous or liquid reagents, and bioremediation to treat source area contamination and disperse areas of the plumes not currently treated by the in situ REDOX manipulation technology (remediation technical element; Id. No. Rem-4 through Rem-7).

- Evaluate reduction and immobilization of technetium-99 and uranium, including small colloidal particle injection and bioremediation (remediation technical element; Id. No. Rem-8 through Rem-10).

- Remediating carbon tetrachloride is initially focused on resolving whether the carbon tetrachloride is present as a DNAPL in the vadose zone and groundwater. Characterization technologies are needed (remediation technical element; Rem-11), and remediation technologies need to be evaluated for Hanford Site conditions (remediation technical element; Rem-12 through 15).

Integrate Site-Monitoring Needs to meet regulatory requirements and to support individual projects in obtaining important data for project-specific objectives. To meet the needs of this groundwater protection element, additional high-priority monitoring wells will be constructed, and technology development for remote monitoring and data-collection efforts will continue. Long-term stewardship needs will be factored into planning for groundwater monitoring. The following S\&T activities have been identified for coordination with the Groundwater Protection Program and integration of site monitoring needs. (Note: A more complete description of the S\&T outcomes, interfaces, and schedules can be found in Section 4 [Table 4.1 through Table 4.4]. The Id. No. for each S\&T outcome is listed in parentheses below to aid the reader in identifying the S\&T outcomes [in Table 4.2] that provide input to the monitoring projects.)

- Develop and/or deploy sensors for monitoring key Hanford contaminants in groundwater, including chromium, strontium-90, technetium-99, uranium, iodine-129, and tritium (subsurface transport technical element; Id. No. ST-24)

- Develop the monitoring technical element in future S\&T activities. At that time, the outcomes will be integrated with the groundwater monitoring project to provide 1) technical support for advanced technologies associated with sampling and analysis, e.g., advanced sensors, 2) development and application of advanced monitoring strategies, e.g., use of stable isotope geochemistry, waste-specific fingerprints, and 3) application of predictive modeling to support monitoring network design and waste-site closure. 


\subsection{Prioritization of Science and Technology Activities}

The S\&T Project used a prioritization process in developing the Rev. 0 roadmap (DOE 1999a) to assure that investments were made in activities that have the greatest potential for improving site decisions. In the Rev. 0 roadmap, a project activity derived its basic priority from two fundamental considerations: 1) the relative importance of the decisions it is intended to affect and 2) the anticipated impact it will have on those decisions. S\&T activities derive their priority from their ability to improve the technical basis for key decisions. The Rev. 1 S\&T roadmap (DOE 2000) maintained the relative priority of activities in the Rev. 0 roadmap and added an activity (Biological Fate and Transport) to initiate work scope within the risk technical element. During the detailed planning process for each year, scheduling, cost, and budget characteristics further determine whether (and how) an activity is supported.

To prepare for FY03 detailed work planning, a prioritization process was conducted involving the core projects, staff from the Integration Project (now the Groundwater Protection Program), and DOE Richland Operations. The steps in the prioritization process were to:

- determine objectives/criteria for prioritization (the resulting criteria fell into two broad categories: Accelerate the Baseline and Fill Knowledge Gaps)

- identify alternatives, consisting of 64 activities, supported by a paragraph description of the work scope (these activities were combined to create 21 categories that were prioritized)

- identify or construct scales to measure the scoring (the scales included qualitative criteria of high, medium, or low priority, technical implementability, and time saved)

- map the qualitative scales onto a 0 to 1 value function that was used to calculate the overall scores for the activities

- assess weights to capture the relative importance of the criteria

- score proposed activities on scales

- determine overall value of alternatives

- perform sensitivity analysis.

The actual calculations and sensitivity analysis were carried out using Logical Decisions, a commercially available software program for decision support. The scoring process began with a discussion of the alternatives and their descriptions, followed by review of the criteria and weights. The overall consensus was that the criteria captured most of the concerns relevant to S\&T prioritization and that the weights seemed reasonable. The exact definitions of the criteria were occasionally somewhat modified during the discussion and scoring process to better reflect the importance of activities. All the projects were scored on a given criterion before considering the next criterion. Given the subjective nature of the scales, this helped to assure consistency of scoring across the alternatives. For the most part, there was consensus on the project scores. For the few cases in which there was some difference of opinion, the score was based on the majority opinion. The results are shown in Figure 6.1.

Sensitivity analyses were used to explore the impact that changes in criteria weights would have on the rankings. The rankings were robust to reasonable changes in the weights. Overall, the sensitivity analysis increased confidence in the rankings. 
The prioritization results are similar to the previous prioritization for Rev. 0:

- Develop methods to estimate inventories for which historical records are missing and characterization data are not accurate. This work, being done with the Soil Inventory Model, was ranked as the highest priority in the Rev. 0 roadmap.

- Develop models for mobility and transport of key contaminants important for site-wide and sitespecific assessments, including uranium, technetium, strontium-90, plutonium and americium, chromium, and carbon tetrachloride. These models will be developed for the vadose zone.

- Develop quantitative conceptual models for tank farm and central plateau waste sites. Specific examples include the work completed for the S-SX and B-BX-BY tank farms and the work planned for remaining tank farms (T-TX-TY, U, A/AX, and C). As in previous versions of the roadmap, this set of activities, in combination with the previous set, was rated high because of opportunities to leverage planned field activities.

- Perform ecological risk-assessment activities, including biological fate-and-transport experiments to quantify uptake to varying concentrations of key contaminants, including strontium-90, iodine-129, chromium, and uranium and to perform enhanced ecological characterization of the river corridor.

- Develop the next generation of source term release models, e.g., release models for single-shell tank contaminants, to be used in site-wide and site-specific assessments.

- Perform recharge studies to develop improved estimates of recharge from vadose-zone monitoring and field experiments. Deploy advanced characterization and monitoring technologies at waste sites.

- Complete vadose-zone transport field studies, including a planned reactive transport field experiment with uranium, and develop scaled parameters for use in simpler assessment models.

- Develop characterization and remediation technologies for carbon tetrachloride, technetium-99, and uranium.

- Develop technologies for cost-effective and large-scale evaluation of surface-barrier hydrologic performance.

As has been previously described in Section 5.6, activities in the roadmap are aligned with Strategic Initiatives 5 and 6 of the Performance Management Plan. High priority will be given to activities that support these initiatives, including:

- inventory estimation methods and geochemical studies of uranium and strontium-90 mobility and transport that support high-risk source control, specifically the U Plant regional closure plans and shrinking the footprint of contaminated area

- technology development for remediation of technetium-99 and uranium to support high-risk source control

- technology-development activities associated with testing and monitoring a surface barrier that meets RCRA-modified C requirements to support high-risk source control and shrinking the footprint of contaminated area

- technology development for characterization and monitoring of subsurface moisture and contaminant plumes and recharge characterization to support reducing recharge conditions 
- development and evaluation of technologies for phytoremediation and sequestration of strontium-90, remediation of chromium in the vadose zone and groundwater, and reduction and immobilization of technetium-99 and uranium to resolve the current groundwater pump-and-treat operations

- development of methods for characterization and remediation of carbon tetrachloride, including resolution of whether the carbon tetrachloride is present as a DNAPL in the vadose zone and groundwater to resolve pump-and-treat and vapor-extraction systems

- development and/or deployment of sensors for monitoring key Hanford contaminants in groundwater, including chromium, strontium-90, technetium-99, uranium, iodine-129, and tritium to support the integration of site monitoring needs. 
Table 6.1. Categories of Science and Technology Activities for Prioritization

\begin{tabular}{|c|c|c|}
\hline S\&T Category & ID Nos. & "Scope Statement \\
\hline $\begin{array}{ll}\text { 1. Inventory - Soil Inventory } \\
\text { Model (SIM) Development }\end{array}$ & Inv-1, 2, 3, 4 & $\begin{array}{l}\text { Develop and document the next generation of SIM, including developing global } \\
\text { estimates of uncertainty for Hanford operations, methods for uncertainty } \\
\text { propagation, and process-knowledge improvement. SIM will be applied to } \\
\text { develop inventory estimates with associated uncertainties to support site-wide and } \\
\text { site-specific assessments. }\end{array}$ \\
\hline $\begin{array}{l}\text { 2. Vadose-Zone Transport } \\
\text { Field Studies }\end{array}$ & ST-1, 2, 3 & $\begin{array}{l}\text { Perform vadose-zone transport field experiments in heterogeneous sediments, } \\
\text { including reactive transport of uranium, derivation of effective flow-and-transport } \\
\text { parameters, and application of advanced vadose-zone characterization and } \\
\text { monitoring technologies. These characterization and monitoring tools will be } \\
\text { used to support remedial investigations and vadose monitoring. }\end{array}$ \\
\hline 3. Recharge Studies & ST-4 & $\begin{array}{l}\text { Provide improved estimates of recharge using data from vadose-zone monitoring } \\
\text { and field experiments. Deploy advanced vadose-zone monitoring technologies at } \\
\text { waste sites, including tank farm, past practice discharge sites, and burial grounds, } \\
\text { to characterize variability in recharge at the Hanford Site. These data will be used } \\
\text { in site-wide and site-specific modeling as well as to assist with surface barrier } \\
\text { design. }\end{array}$ \\
\hline $\begin{array}{l}\text { 4. Source-Term Release } \\
\text { Models }\end{array}$ & ST-5 & $\begin{array}{l}\text { Enhance existing source-term release models or develop new models. Develop } \\
\text { the next generation of release models, e.g. release models for SST contents } \\
\text { including salt cake, sludge, and hard heel. These results will be used in site-wide } \\
\text { and site-specific assessments to characterize and predict source-term release. }\end{array}$ \\
\hline $\begin{array}{l}\text { 5. Linkage of models at } \\
\text { different scales }\end{array}$ & ST-6, 18 & $\begin{array}{l}\text { Develop a method for adopting results from detailed, site-specific models of } \\
\text { inventory, contaminant release, and transport, e.g. reactive transport, as input to } \\
\text { site-wide models. Address the issue of scaleup and the impacts of multiple scales } \\
\text { of heterogeneity on subsurface flow and transport. These results will be used in } \\
\text { site-wide assessments to scale results from more detailed models. }\end{array}$ \\
\hline $\begin{array}{l}\text { 6. Models for mobility and } \\
\text { transport of key } \\
\text { contaminants important for } \\
\text { site-wide assessment }\end{array}$ & ST- $7,8,9,10,11,12,13$ & $\begin{array}{l}\text { Evaluate in-ground speciation and develop mobility models for key contaminants } \\
\text { in site-wide risk assessments and site-specific areas, including uranium and } \\
\text { technetium, strontium-90, iodine-129, plutonium and americium, chromium, and } \\
\text { carbon tetrachloride. Evaluate the impacts of organic complexants on the mobility } \\
\text { of key contaminants. These models will be used to support site-wide and site- } \\
\text { specific risk assessments and to assist in making remediation decisions. }\end{array}$ \\
\hline
\end{tabular}


Table 6.1 (Contd)

\begin{tabular}{|c|c|c|}
\hline S\&T Category & ID Nos. & Scope Statement \\
\hline $\begin{array}{l}\text { 7. Quantitative conceptual } \\
\text { models for tank farm and } \\
\text { central plateau waste sites }\end{array}$ & ST-14, 15,16 & $\begin{array}{l}\text { Perform speciation and microscopy measurements and laboratory manipulation } \\
\text { experiments on contaminated sediments to define the geochemical behavior of } \\
\text { contaminants in representative waste sites. Provide input to characterization } \\
\text { reports by Site remediation contractors. }\end{array}$ \\
\hline $\begin{array}{l}\text { 8. Reactive transport models } \\
\text { to support remediation } \\
\text { design }\end{array}$ & ST-17 & $\begin{array}{l}\text { Develop and implement reactive transport models for design of remediation } \\
\text { systems, including codes that support evaluation of reaction kinetics, } \\
\text { incorporation of hydrogeological and geochemical heterogeneities, and } \\
\text { reaction/mobility of key contaminants. }\end{array}$ \\
\hline 9. Groundwater modeling & ST-19, 20 & $\begin{array}{l}\text { Evaluate historical groundwater data to interpret three-dimensional groundwater } \\
\text { plumes at the interface with the vadose zone and develop dispersivity estimates } \\
\text { for key groundwater contaminants. Collect additional depth-discrete data where } \\
\text { tank leaks have impacted groundwater to characterize the vadose-groundwater } \\
\text { interface. Interpret historical groundwater data to determine dispersivity as a } \\
\text { function of travel distance and hydrogeologic unit. These data will be used in } \\
\text { groundwater-flow and contaminant-transport models at the Site. }\end{array}$ \\
\hline $\begin{array}{l}\text { 10. Groundwater/river } \\
\text { interface }\end{array}$ & ST-21, 22, 23 & $\begin{array}{l}\text { Collect data and develop methods for characterizing the groundwater-river } \\
\text { interface to support contaminant discharge to the Columbia River under highly } \\
\text { variable conditions caused by river-level fluctuations. Information will be used to } \\
\text { support site-wide and site-specific risk assessments in addition to determining } \\
\text { appropriate cleanup criteria for waste sites adjacent to the river. }\end{array}$ \\
\hline 11. Monitoring technologies & ST-24 & $\begin{array}{l}\text { Develop and/or deploy sensors for monitoring key Hanford contaminants, } \\
\text { including chromium, strontium-90, technetium-99, uranium, iodine-129, and } \\
\text { tritium. Sensors will be deployed for long-term stewardship. }\end{array}$ \\
\hline $\begin{array}{l}\text { 12. Enhanced ecological } \\
\text { characterization of river } \\
\text { corridor }\end{array}$ & CRR-1, 2 & $\begin{array}{l}\text { Investigate ecological and contaminant fate and transport in the river environment } \\
\text { to support site-wide and site-specific risk assessments. Includes evaluation of } \\
\text { physical, chemical, and biological processes that reduce contaminant } \\
\text { concentrations, mass, mobility, and/or toxicity at the groundwater/river interface. } \\
\text { Will provide data to support risk assessments and remediation decisions for the } \\
100 \text { and } 300 \text { Area river corridor. }\end{array}$ \\
\hline
\end{tabular}


Table 6.1 (Contd)

\begin{tabular}{|c|c|c|}
\hline S\&T Category & ID Nos. & Scope Statement \\
\hline $\begin{array}{l}\text { 13. Entrainment of river water } \\
\text { in bed sediment }\end{array}$ & CRR-4 & $\begin{array}{l}\text { Investigate geomorphic controls on entrainment of river water in bed sediments } \\
\text { and conduct field experiments to determine the impact of river water on pore- } \\
\text { water quality relative to groundwater flow at locations where key contaminants } \\
\text { are discharging to the river, e.g.. strontium- } 90 \text { at } 100-\mathrm{N} \text {, uranium in the } 300 \text { Area } \\
\text { and chromium plumes }\end{array}$ \\
\hline $\begin{array}{l}\text { 14. River monitoring } \\
\text { technologies }\end{array}$ & CRR-5, 6 & $\begin{array}{l}\text { Develop and deploy cost effective in situ monitoring instruments for water } \\
\text { quality; identify and characterize biological sentinels that are influenced by } \\
\text { contaminants or are indicative of environmental stresses. Improvements are } \\
\text { needed to deploy in situ sensors for strontium- } 90 \text {, chromium, and uranium in the } \\
\text { river. Techniques are needed for measuring indicators of biological uptake and } \\
\text { impact. These sensors and methods will be used to support long-term monitoring } \\
\text { of the river system. }\end{array}$ \\
\hline 15. Ecological risk assessment & CRR-7, 8, 9 & $\begin{array}{l}\text { Quantify the changes in uptake (absorption factors) to varying concentrations of } \\
\text { key contaminants, including strontium-90, iodine- } 129 \text {, chromium, and uranium. } \\
\text { Quantify the bioavailability of selected Hanford Site contaminants to } \\
\text { representative riparian and aquatic species. Develop exposure scenarios for } \\
\text { selected organisms exposed to multiple media. The outcome of these activities } \\
\text { will be documented databases for bioavailability, uptake responses, and exposure } \\
\text { scenarios to support site-wide and site-specific risk assessments. }\end{array}$ \\
\hline $\begin{array}{l}\text { 16. Human health risk } \\
\text { assessment }\end{array}$ & CRR-10, 11, 12 & $\begin{array}{l}\text { Evaluate contaminant bioavailability in the environment and its impact on the } \\
\text { availability of selected contaminants for human uptake. Develop food-chain } \\
\text { transfer factors for selected contaminants to characterize the impacts of food } \\
\text { processing on the concentrations of contaminants in food products. Develop } \\
\text { processes to quantify impacts of river and groundwater contamination on human } \\
\text { health and ecological receptors to support risk-based decision making. The } \\
\text { outcome of these activities will be documented data and approaches to support } \\
\text { site-wide and site-specific risk assessments. }\end{array}$ \\
\hline
\end{tabular}


Table 6.1 (Contd)

\begin{tabular}{|c|c|c|}
\hline S\&T Category & ID Nos. & Scope Statement \\
\hline $\begin{array}{l}\text { 17. } 100-\mathrm{N} \text { strontium-90 } \\
\text { remediation }\end{array}$ & Rem- $1,2,3$ & $\begin{array}{l}\text { Evaluate data for and the feasibility of phytoremediation and immobilization } \\
\text { technologies for strontium- } 90 \text { at } 100-\mathrm{N} \text { Area. Includes evaluation of monitored } \\
\text { natural attenuation, including methods for biological monitoring. Support } \\
\text { feasibility studies of the remediation technologies. Results will support } \\
\text { determination of alternatives to the baseline pump-and-treat system for } \\
\text { groundwater remediation at } 100-\mathrm{N} \text {. }\end{array}$ \\
\hline 18. Chromium remediation & Rem-4, 5, 6, 7 & $\begin{array}{l}\text { Evaluate remediation technologies for remediation of chromium in the vadose } \\
\text { zone and groundwater, including in situ gaseous reduction, other gaseous or liquid } \\
\text { reagents, and bioremediation. The results of these evaluations will be used to } \\
\text { support remediation of source-area vadose-zone contamination and dispersed } \\
\text { areas of the plumes not currently treated by in situ REDOX manipulation or } \\
\text { groundwater pump-and-treat operations. Will lead to final remedies for } \\
\text { chromium. }\end{array}$ \\
\hline $\begin{array}{l}\text { 19. Technetium-99 and } \\
\text { uranium remediation }\end{array}$ & Rem- $8,9,10$ & $\begin{array}{l}\text { Evaluate reduction and immobilization methods for technetium- } 99 \text { and uranium, } \\
\text { including SAMMS and bioremediation. Includes evaluation of methods for } \\
\text { injecting small colloidal particles. Results will need to provide final remedies for } \\
\text { technetium- } 99 \text { and uranium. }\end{array}$ \\
\hline $\begin{array}{l}\text { 20. Carbon tetrachloride } \\
\text { characterization and } \\
\text { remediation }\end{array}$ & Rem-11, 12, 13, 14, 15 & $\begin{array}{l}\text { Evaluate characterization and remediation technologies for carbon tetrachloride. } \\
\text { The existing technologies for characterizing carbon tetrachloride in the vadose } \\
\text { zone and groundwater are expensive and limit the extent of investigations. The } \\
\text { current technologies for remediation of carbon tetrachloride are inadequate. } \\
\text { Results of these activities will be used to accelerate characterization and } \\
\text { remediation of carbon tetrachloride in the subsurface at Hanford. }\end{array}$ \\
\hline $\begin{array}{l}\text { 21. Surface barrier technology } \\
\text { development }\end{array}$ & Rem-16, 17, 18, 19, 20 & $\begin{array}{l}\text { Evaluate technologies for cost-effective and large-scale evaluation of barrier } \\
\text { hydrologic performance, support feasibility test for modified Hanford barrier to } \\
\text { meet RCRA Modified C requirements, evaluate side-slope issues and asphalt or } \\
\text { other barrier materials, and develop data, such as ecological characteristics, to } \\
\text { support optimal design. }\end{array}$ \\
\hline
\end{tabular}


Ranking for Value for S\&T Goal

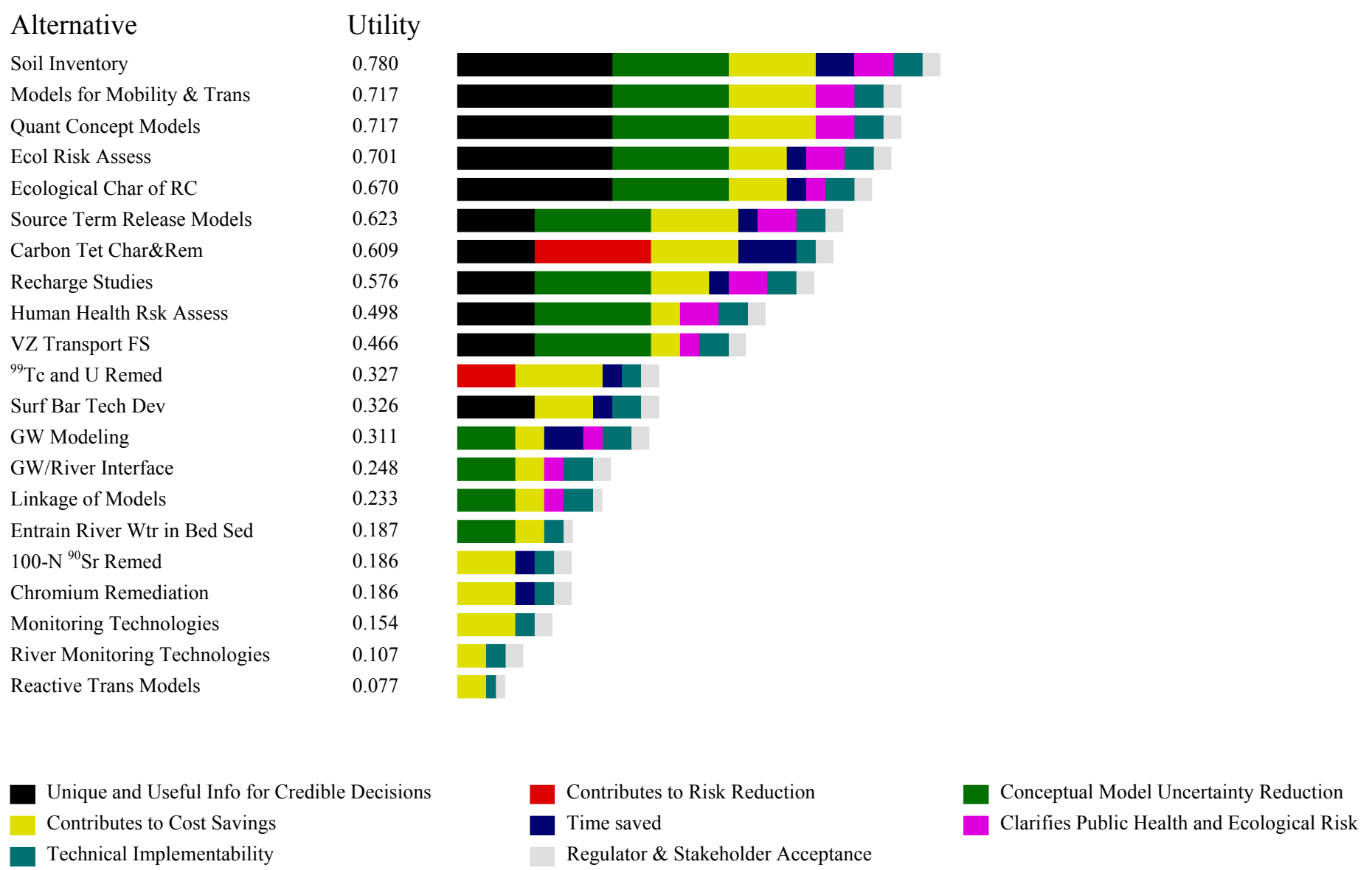

Figure 6.1. Ranking Results for S\&T Categories 


\subsection{Budget Summary}

The budget for the S\&T activities proposed for the next 5 years is provided in Table 7.1. These estimates were based on the envisioned scope and past experience with costs for similar S\&T activities. The budget for each S\&T activity was split between site-provided funding (which was developed based on DOE guidance) and potential leveraged funding being sought by the Integration Project. All budget estimates will be refined subsequent to detailed FY03 planning and beyond, prioritized as described in Section 6.0, and based on the acceleration initiatives planned by DOE Richland and ORP.

Table 7.1. Proposed Five-Year Budget for S\&T Activities

\begin{tabular}{|c|c|c|c|c|c|c|c|}
\hline $\begin{array}{l}\text { Technical } \\
\text { Element }\end{array}$ & S\&T Activity & $\begin{array}{c}\text { FY02 } \\
\text { Existing }\end{array}$ & $\begin{array}{l}\text { FY03 } \\
\text { (\$K) }\end{array}$ & $\begin{array}{l}\text { FY04 } \\
\text { (\$K) }\end{array}$ & $\begin{array}{l}\text { FY05 } \\
\text { (\$K) }\end{array}$ & $\begin{array}{l}\text { FY06 } \\
\text { (\$K) }\end{array}$ & $\begin{array}{l}\text { FY07 } \\
\text { (\$K) }\end{array}$ \\
\hline \multirow{5}{*}{ Inventory } & $\begin{array}{l}\text { Inventory estimation, } \\
\text { uncertainty }\end{array}$ & & 250 & 250 & & & \\
\hline & Waste Stream Predictions & 280 & & & & & \\
\hline & $\begin{array}{l}\text { Process-Knowledge } \\
\text { Improvement }\end{array}$ & & & 250 & & & \\
\hline & $\begin{array}{l}\text { Field Confirmation of } \\
\text { Inventory Composition }\end{array}$ & & 50 & 50 & & & \\
\hline & Totals: & 280 & 300 & 550 & & & \\
\hline \multirow{14}{*}{$\begin{array}{l}\text { Subsurface } \\
\text { Transport }\end{array}$} & $\begin{array}{l}\text { Vadose-Zone Transport } \\
\text { Field Study Effective } \\
\text { Flow Parameters }\end{array}$ & & 150 & 150 & & & \\
\hline & $\begin{array}{l}\text { VZTFS Uranium Reactive } \\
\text { Transport Experiment }\end{array}$ & 1302 & 1500 & & & & \\
\hline & Recharge Assessments & & 200 & 200 & 200 & 200 & 200 \\
\hline & $\begin{array}{l}\text { Release Model } \\
\text { Development }\end{array}$ & & 100 & 80 & & & \\
\hline & $\begin{array}{l}\text { Linkage of Stochastic } \\
\text { Models }\end{array}$ & & 250 & & & & \\
\hline & Uranium Mobility Model & 250 & 250 & & & & \\
\hline & $\begin{array}{l}\text { Strontium-90 Mobility } \\
\text { Model }\end{array}$ & 300 & 300 & & & & \\
\hline & $\begin{array}{l}\text { Iodine-129 Mobility } \\
\text { Model }\end{array}$ & & & 300 & & & \\
\hline & $\begin{array}{l}\text { Speciation and Mobility of } \\
\text { Transuranics }\end{array}$ & & & & 300 & & \\
\hline & $\begin{array}{l}\text { Organic Complexant } \\
\text { Effects }\end{array}$ & & & 200 & 200 & & \\
\hline & $\begin{array}{l}\text { Chromium Mobility } \\
\text { Model }\end{array}$ & & & & & 200 & \\
\hline & $\begin{array}{l}\text { Carbon Tetrachloride } \\
\text { Transport and Mobility }\end{array}$ & 150 & 300 & 300 & & & \\
\hline & $\begin{array}{l}\text { Quantitative Conceptual } \\
\text { Models B-BX-BY }\end{array}$ & 983 & & & & & \\
\hline & $\begin{array}{l}\text { Quantitative Conceptual } \\
\text { Models T-TX-TY }\end{array}$ & 275 & 500 & 500 & & & \\
\hline
\end{tabular}


Table 7.1 (Contd)

\begin{tabular}{|c|c|c|c|c|c|c|c|}
\hline $\begin{array}{l}\text { Technical } \\
\text { Element }\end{array}$ & S\&T Activity & $\begin{array}{c}\text { FY02 } \\
\text { Existing }\end{array}$ & $\begin{array}{l}\text { FY03 } \\
\text { (\$K) }\end{array}$ & $\begin{array}{l}\text { FY04 } \\
\text { (\$K) }\end{array}$ & $\begin{array}{l}\text { FY05 } \\
\text { (\$K) }\end{array}$ & $\begin{array}{c}\text { FY06 } \\
\text { (\$K) }\end{array}$ & $\begin{array}{l}\text { FY07 } \\
\text { (\$K) }\end{array}$ \\
\hline \multirow{5}{*}{$\begin{array}{l}\text { Subsurface } \\
\text { Transport }\end{array}$} & $\begin{array}{l}\text { Quantitative Conceptual } \\
\text { Models U, A/AX, C }\end{array}$ & & & & 500 & 500 & \\
\hline & $\begin{array}{l}\text { Scaling Reactive- } \\
\text { Transport Properties }\end{array}$ & & & 250 & 250 & & \\
\hline & $\begin{array}{l}\text { Groundwater-River } \\
\text { Interface Remote Sensing }\end{array}$ & & 150 & & & & \\
\hline & $\begin{array}{l}\text { Groundwater-River } \\
\text { Interface and Uncertainty } \\
\text { Scaling }\end{array}$ & 123 & 150 & & & & \\
\hline & Totals & 3383 & 3850 & 1930 & 1450 & 900 & 200 \\
\hline \multirow{9}{*}{$\begin{array}{l}\text { Columbia } \\
\text { River and } \\
\text { Risk }\end{array}$} & $\begin{array}{l}\text { Enhanced Ecological } \\
\text { Characterization } 300 \text { Area }\end{array}$ & & 350 & & & & \\
\hline & $\begin{array}{l}\text { Enhanced Ecological } \\
\text { Characterization } 100 \text { Area }\end{array}$ & & & 350 & & & \\
\hline & $\begin{array}{l}\text { River-Water Entrainment } \\
\text { in Bed Sediments }\end{array}$ & & & & 300 & & \\
\hline & $\begin{array}{l}\text { Biological Fate and } \\
\text { Transport Uptake of } \\
\text { Strontium-90, Iodine-129, } \\
\text { Uranium, and Chromium }\end{array}$ & 439 & 250 & 250 & & & \\
\hline & $\begin{array}{l}\text { Modifiers to Ecological } \\
\text { Exposures }\end{array}$ & & & & 250 & 250 & \\
\hline & $\begin{array}{l}\text { Contaminant } \\
\text { Bioavailability in } \\
\text { Environment }\end{array}$ & & & & & 150 & 150 \\
\hline & $\begin{array}{l}\text { Food-Chain Transfer } \\
\text { Factors }\end{array}$ & & & & & & 200 \\
\hline & $\begin{array}{l}\text { Quantification of Risk } \\
\text { Decision Metrics }\end{array}$ & & & & & & 150 \\
\hline & Totals & 439 & 600 & 600 & 550 & 400 & 500 \\
\hline \multirow{10}{*}{ Remediation } & $\begin{array}{l}\text { Strontium-90 Alternative } \\
\text { Concentration Monitoring }\end{array}$ & & 250 & 250 & 50 & 50 & 50 \\
\hline & $\begin{array}{l}\text { Strontium-90 } \\
\text { Phytoremediation }\end{array}$ & & 600 & 750 & 500 & 180 & 180 \\
\hline & $\begin{array}{l}\text { Strontium-90 } \\
\text { Immobilization }\end{array}$ & & 400 & 450 & 1000 & 1200 & 450 \\
\hline & Chromium Remediation & & & & 200 & 500 & 500 \\
\hline & $\begin{array}{l}\text { Chromium Source } \\
\text { Reduction }\end{array}$ & & & & & 500 & 500 \\
\hline & ISRM Cost Reduction & & & & 250 & 250 & \\
\hline & $\begin{array}{l}\text { Technetium-99 and } \\
\text { Uranium Reduction and } \\
\text { Immobilization }\end{array}$ & & & 500 & 500 & & \\
\hline & $\begin{array}{l}\text { Injection of Colloidal } \\
\text { Particles }\end{array}$ & & & 500 & 500 & & \\
\hline & $\begin{array}{l}\text { Carbon Tetrachloride } \\
\text { Steam Injection }\end{array}$ & & & & 500 & 1000 & \\
\hline & $\begin{array}{l}\text { Carbon Tetrachloride Six- } \\
\text { Phase Heating }\end{array}$ & & & & & 500 & 1000 \\
\hline
\end{tabular}


Table 7.1 (Contd)

\begin{tabular}{|c|c|c|c|c|c|c|c|}
\hline $\begin{array}{l}\text { Technical } \\
\text { Element }\end{array}$ & S\&T Activity & $\begin{array}{c}\text { FY02 } \\
\text { Existing }\end{array}$ & $\begin{array}{c}\text { FY03 } \\
\text { (\$K) }\end{array}$ & $\begin{array}{l}\text { FY04 } \\
\text { (\$K) }\end{array}$ & $\begin{array}{l}\text { FY05 } \\
\text { (\$K) }\end{array}$ & $\begin{array}{l}\text { FY06 } \\
\text { (\$K) }\end{array}$ & $\begin{array}{l}\text { FY07 } \\
\text { (\$K) }\end{array}$ \\
\hline \multirow{5}{*}{ Remediation } & $\begin{array}{l}\text { Control of Carbon } \\
\text { Tetrachloride } \\
\text { Groundwater Plume } \\
\text { (Modeling Study) }\end{array}$ & & & 150 & & & \\
\hline & $\begin{array}{l}\text { Surface-Barrier Plant } \\
\text { Ecology Studies }\end{array}$ & & & 150 & 250 & 250 & \\
\hline & $\begin{array}{l}\text { Surface-Barrier Sideslope } \\
\text { Studies }\end{array}$ & & & 250 & 250 & & \\
\hline & $\begin{array}{l}\text { Surface-Barrier Asphalt } \\
\text { Durability Testing }\end{array}$ & & & 250 & 250 & & \\
\hline & Totals & $\mathbf{0}$ & 1250 & 3000 & 4000 & 4680 & 2930 \\
\hline Roadmap & & 550 & 550 & 550 & 550 & 550 & 550 \\
\hline Totals & & 4902 & 6550 & 6630 & 6550 & 6530 & 4180 \\
\hline
\end{tabular}




\subsection{References}

Barnett DB, GW Gee, and MH Sweeney. 2002. Results of Tank Leak Detection Demonstration Using Geophysical Techniques at the Hanford Site Mock Tank Site-Fiscal Year 2001. PNNL-13818, Pacific Northwest National Laboratory, Richland, WA.

Bechtel Hanford, Inc. (BHI). 2000. Technical Memorandum for the 100-N ITRD Bank Stability Evaluation. BHI-01324, Rev. 0, Bechtel Hanford, Inc., Richland, WA.

Bryce RW, CT Kincaid, PW Eslinger, and LF Morasch, eds. 2002. An Initial Assessment of Hanford Impact Performed with the System Assessment Capability. PNNL-14027, Pacific Northwest National Laboratory, Richland, WA.

Cameron RJ, JC Evans, MD Johnson, and TL Liikala. 2002. Summary of Hanford Subsurface Air Flow and Extraction (SAFE) Activities for FY 2001. PNNL-13820, Pacific Northwest National Laboratory, Richland, WA.

DOE-RL, see U.S. Department of Energy-Richland Operations

Gee GW, and AL Ward. 2001. Vadose Zone Transport Field Study: Status Report. PNNL-13679, Pacific Northwest National Laboratory, Richland, WA.

Innovative Treatment and Remediation Demonstration Program (ITRD). 2002a. Hanford 100-N Area Remedial Options Evaluation Summary Report. Innovative Treatment and Remediation Demonstration Program, Sandia National Laboratory, Albuquerque, NM.

Innovative Treatment and Remediation Demonstration Program (ITRD). 2002b. Hanford 200-West Area Carbon Tetrachloride Project Innovative Remediation Technology Review, 1999-2000. Innovative Treatment and Remediation Demonstration Program, Sandia National Laboratory, Albuquerque, NM.

MSE Technology Applications, Inc. (MSE). 1999. Hanford 100-N Soil Flushing Phase I Report. (Unpublished white paper for the ITRD Program) MSE Technology Applications, Inc., Butte, MT.

MSE Technology Applications, Inc. (MSE). 2000. Hanford 100-N Soil Flushing Phase II Report. (Unpublished white paper for the ITRD Program) MSE Technology Applications, Inc., Butte, MT.

National Research Council. 2001. Science and Technology for Environmental Cleanup at Hanford. National Research Council, Washington, D.C.

River Protection Project (RPP). 2002a. Field Investigation Report for Waste Management Area S-SX. RPP-7884, Rev. 0, Prepared for the Office of River Protection by CH2M Hill Hanford Group, Richland, WA.

River Protection Project (RPP). 2002b. Office of River Protection FY 2002 Integrated Technology Plan. DOE/ORP-2002-03, U.S. Department of Energy, Office of River Protection, Richland, WA. 
Simpson BC, RA Corbin, and SF Agnew. 2001. Hanford Soil Inventory Model. BHI-01496, Bechtel Hanford, Inc., Richland, WA.

Tri-Party Agreement (TPA). 1989. Hanford Federal Facility Agreement and Consent Order, as amended, Washington State Department of Ecology, U.S. Environmental Protection Agency, and U.S. Department of Energy, Olympia, Washington.

U.S. Department of Energy-Richland Operations (DOE-RL). 1999a. Groundwater/Vadose Zone Integration Project Science and Technology Summary Description. DOE/RL-98-48, Vol. III, Rev. 0, U.S. Department of Energy, Richland Operations Office, Richland, WA.

U.S. Department of Energy-Richland Operations (DOE-RL). 1999b. 200-BP-1 Prototype Barrier Treatability Test Report, DOE/RL-99-11, Rev. 0, U.S. Department of Energy, Richland Operations Office, Richland, WA.

U.S. Department of Energy-Richland Operations (DOE-RL). 2000. Groundwater/Vadose Zone Integration Project Science and Technology Summary Description. DOE/RL-98-48, Vol. III, Rev. 1, U.S. Department of Energy, Richland Operations Office, Richland, WA. 
PNNL-14092

\section{DISTRIBUTION}

No. of

Copies

OFFSITE

Martin Bensky

2121 Briarwood Ct.

Richland, WA 99352

Don Clark

DEC Enterprises

2519 Cordoba

Richland, WA 99352

Dirk Dunning

Sue Safford

Tom Stoops

Oregon Office of Energy

625 Marion St. NE, Suite 1

Salem, OR 97301

Sandra Lilligren

Nez Perce Tribe

P. O. Box 365

Lapwai, ID 83540

Ted Repasky

Rod Skeen

Confederated Tribes of the Umatilla Indian

Reservation

P. O. Box 638

Pendleton, OR 97801

Wade Riggsby

Yakama Nation

2808 Main St.

Union Gap, WA 98903

Gordon Rogers

1108 N. Road 36

Pasco, WA 99301
No. of

Copies

\section{OFFSITE}

Douglas R. Sherwood

1616 Riverside Drive

West Richland, WA 99353

\section{ONSITE}

7 U.S. Department of Energy-Richland Operations Office

W. W. Ballard

A5-12

R. D. Hildebrand

A6-38

J. P. Hanson

A5-13

K. D. Leary

A6-38

K. M. Thompson (5)

A6-38

A. C. Tortoso

A6-38

DOE-RL Public Reading Room

$\mathrm{H} 2-53$

2 U.S. Department of Energy-Office of River Protection
R. W. Lober
H6-60
R. M. Yasek
H6-60

5 Fluor Hanford, Inc.
T. W. Fogwell
E6-35
B. H. Ford
E6-35
R. L. Jackson
E6-35
S. W. Petersen
E6-35
R. T. Wilde
E6-35

2 CH2M Hill Hanford Group, Inc.
A. J. Knepp
E6-35
F. M. Mann
E6-35

Distr. 1 
No. of

Copies

ONSITE

4 Washington State Department of Ecology

J. Caggiano

B5-18

D. Goswami

B5-18

J. A. Hedges

B5-18

J. Price

B5-18

2 U.S. Environmental Protection Agency

N. Ceto

D. A. Faulk
B5-01

B5-01
No. of

Copies

\section{ONSITE}

25 Pacific Northwest National Laboratory

R. W. Bryce

K6-76

A. L. Bunn

K6-85

R. L. Dirkes

K6-75

M. D. Freshley (15)

K9-33

G. W. Gee

K9-33

T. J. Gilmore

K6-81

C. T. Kincaid

K9-33

T. L. Page

K9-18

R. E. Peterson

K6-96

A. L. Ward

K9-33

J. L. Zachara

K8-96

Distr. 2 